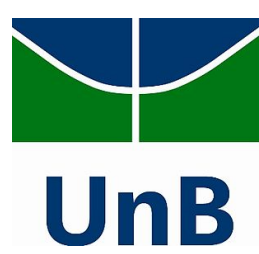

Universidade de Brasília Instituto de Ciências Exatas

Departamento de Matemática

Programa de Mestrado Profissional em Matemática em Rede Nacional

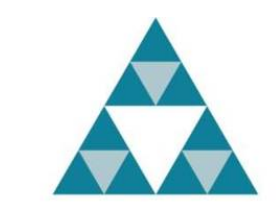

PROFMAT

Rosana de Andrade Araújo Pinto

\title{
A convergência do Projeto Tuning América Latina com as Diretrizes Curriculares Nacionais para a licenciatura em Matemática
}

\author{
Brasília
}


Rosana de Andrade Araújo Pinto

\section{A convergência do Projeto Tuning América Latina com as Diretrizes Curriculares Nacionais para a licenciatura em Matemática}




\title{
A convergência do Projeto Tuning América Latina com as Diretrizes Curriculares Nacionais para a licenciatura em Matemática
}

\author{
Monografia apresentada à Comissão Examina- \\ dora do Programa de Pós-Graduação do De- \\ partamento de Matemática, da Universidade \\ de Brasília, como requisito para a obtenção \\ do título de Mestre.
}

\author{
Universidade de Brasília - UnB \\ Instituto de Ciências Exatas \\ Departamento de Matemática \\ Programa de Mestrado Profissional em \\ Matemática em Rede Nacional
}

Orientador: Prof. Dr. Mauro Luiz Rabelo

Brasília

2015 
Ficha catalográfica elaborada automaticamente, com os dados fornecidos pelo(a) autor(a)

A convergência do Projeto Tuning América Latina com as Diretrizes Curriculares Nacionais para a licenciatura em Matemática / Rosana de Andrade Araújo Pinto; orientador Mauro Luiz Rabelo. -Brasília, 2015.

$$
99 \mathrm{p} \text {. }
$$

Dissertação (Mestrado - Mestrado em Matemática) -Universidade de Brasília, 2015.

1. Projeto Tuning:Tuning América Latina para Matemática. 2. Diretrizes Curriculares Nacionais. 3. Crédito Latino-americano de Referência. 4.

Competências. 5. Projeto Pedagógico de Curso. I. Rabelo, Mauro Luiz, orient. II. Título. 
Universidade de Brasília

Instituto de Ciências Exatas

Departamento de Matemática

\section{A convergência do projeto Tuning América Latina com as diretrizes curriculares nacionais para a licenciatura em matemática}

por

\section{ROSANA DE ANDRADE ARAÚJO PINTO*}

Dissertação apresentada ao Departamento de Matemática da Universidade de Brasília, como parte dos requisitos do "Programa" de Mestrado Profissional em Matemática em Rede Nacional - PROFMAT, para obtenção do grau de

\section{MESTRE}

Brasília, 01 de julho de 2015.

Comissão Examinadora:

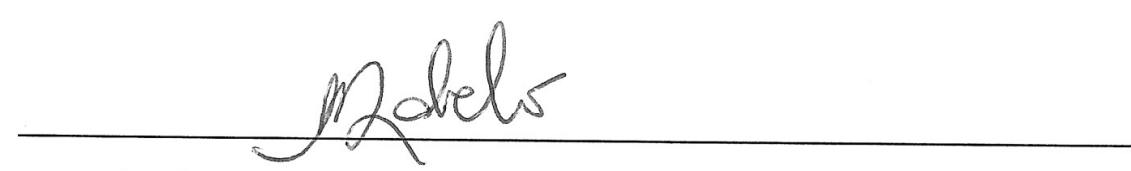

Prof. Dr. Mauro Luiz Rabelo - MAT/UnB (Orientador)
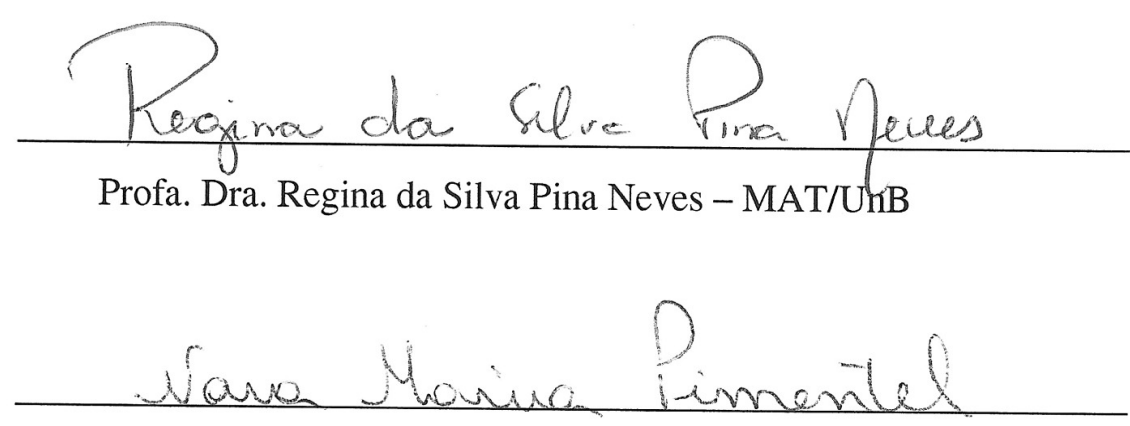

Profa. Dra. Nara Maria Pimentel - FE/UnB

* A autora foi bolsista CAPES durante a elaboração desta dissertação. 
Dedico esse trabalho a todas as famílias, que elas possam ser verdadeiros oásis no mundo moderno e a minha família em especial por ser minha grande fonte restauradora. 


\section{Agradecimentos}

Agradeço a Deus que tornou esse momento possível, e me deu forças para ir em frente.

Ao meu esposo Gerson de Castro meu maior incentivador na superação dos meus limites.

As minhas pequenas filhas Júlia e Joana verdadeiros anjos que o senhor me confiou.

A minha grande amiga Regiane, verdadeira companheira sempre pronta a ouvir e a ensinar com uma delicadeza ímpar e carinho que muito fortaleceu na "fase mestrado".

Ao meu amigo Edson Alves pela colaboração inestimável e pela infinita disponibilidade.

Ao Prof. Dr. Mauro Rabelo pela confiança, pela oportunidade de trabalhar ao seu lado, por todos os ensinamentos e pela impecável condução deste trabalho.

Aos amigos Kleber e Ana Paula, aos professores do curso e a todos pela sensibilidade no compartilhamento deste meu aprendizado, em especial ao colega Jeferson Arruda pelo apoio e presteza. 


\section{Resumo}

O Projeto Tuning é uma rede internacional de comunidades de aprendizado formada por acadêmicos de diversos países que refletem, debatem, elaboram instrumentos e partilham resultados referentes à educação superior. A principal abordagem do projeto Tuning América Latina está na formação centrada no aluno, favorecendo o desenvolvimento de uma reforma curricular embasada em competências, com vistas a favorecer a mobilidade estudantil entre as universidades latinoamericanas. A partir de 2001, alguns documentos que regem a nossa educação foram homologados, entre os quais se destacam as Diretrizes Curriculares Nacionais (DCN), que propõem a formação por competências que possibilitem a obtenção de determinados perfis profissionais. Nesse cenário, este trabalho contribui para verificar a convergência das DCN para as Licenciaturas em Matemática e do Projeto Pedagógico de um curso (PPC) de Licenciatura em Matemática de uma IFES com a proposta do projeto internacional Tuning América Latina na área da matemática. A convergência foi verificada explorando-se pontos semelhantes e distintos, investigando, entre outros fatores, o perfil profissional de formação desejado, os conteúdos e as competências. A metodologia aplicada no trabalho englobou análise documental, bibliográfica e de conteúdo, e a aplicação de um questionário a um grupo de professores da IFES pesquisada com o intuito de investigar em que medida os docentes conhecem o projeto Tuning, as DCN e o PPC do curso no qual atuam. Após análise, ficou evidenciada a confluência entre ambos. Existe, nas propostas, equivalência direta e, entre outras, indiretas, o mesmo ocorrendo como o conteúdo recomendado. A análise do PPC da IFES pesquisada também mostrou pontos de semelhanças com o projeto internacional, mas algumas divergências, entre as quais se sobressai o tempo dedicado ao trabalho requerido por um estudante para lograr bons resultados de aprendizagem, seja sob a supervisão direta do docente ou não. A análise das respostas dos questionários revelou que nenhum dos respondentes sabia da existência do Tuning e apenas $25 \%$ conhecem as DCN do seu curso, revelando a necessidade de um trabalho mais efetivo de conscientização da coordenação pedagógica da unidade acadêmica pesquisada.

Palavras-chave: Projeto Tuning. Tuning América Latina para Matemática. DCN. Competências. Crédito Latinoamericano de Referência. Projeto Pedagógico de Curso. 


\section{Abstract}

The Tuning Project is an international network of learning communities formed by academics from different nations that reflect, discuss, elaborate instruments and share results related to higher education. The main goal of the Tuning Latin America project is the training student-centered, favoring the development of a curriculum reform based in competences, in order to facilitate student's mobility between Latin American universities. Since 2001, some governmental documents for our education have been approved, among them stands out the National Curricular Guidelines (DCN), which proposes training for competences that enable to get certain job profiles. In this setting, this work contributes to verify the convergence of DCN for the Graduation in Mathematics and Educational Program of a course (PPC) Graduation in Mathematics of IFES with the proposal of the international project Tuning Latin America in the area of mathematics. Convergence was checked exploiting similar and different points, investigating, among other factors, the professional profile of desired training, contents and competences. The methodology used at this work involved documental, bibliographic and content analysis and the application of a questionnaire to a IFES group of teachers in order to investigate the extent of the teachers knowledge of the Tuning project, the DCN and the PPC course they operate. After, it evidenced that they're going to the same point. There, among many of the competences listed in the proposals, direct and indirect equivalences, occurring the same as the recommended content. The IFES PPC analysis also showed searched points of similarities to the international project, but some differences, among which stands out the time devoted to the work required for a student to achieve good learning results, is under the direct supervision of teachers or no. The analysis of the responses to the questionnaire had revealed that none of the respondents knew the existence of Tuning and only 25\% know the DCN of their course, revealing the need for further work to raise awareness of the pedagogical coordination of academic unit searched.

Keywords: Tuning Project. Tuning Latin America for Mathematics. DCN. Competences. Credit Reference Latinoamericano. Education Programme Course. 


\section{Lista de ilustrações}

Figura 1 - Estrutura da Educação Tuning na Europa. . . . . . . . . . . . . . . . . 20

Figura 2 - Distribuição das áreas temáticas. . . . . . . . . . . . . . . 23

Figura 3 - Estrutura organizacional do projeto Tuning na América Latina. . . . . 24

Figura 4 - Conhecimento do teor das DCN para o curso de Licenciatura em Matemática por parte dos docentes da IFES . . . . . . . . . . . . . . 71

Figura 5 - Conhecimento do teor das DCN para o curso de Licenciatura em Matemática por professores que ministram aulas na Licenciatura em Matemática 72

Figura 6 - Conhecimento do PPC entre aqueles que atuam na licenciatura . . . . 73

Figura 7 - Conhecimento do PPC entre aqueles que atuam na licenciatura por gênero 73

Figura 8 - Conhecimento do PPC entre aqueles que atuam na licenciatura segundo o tempo de atuação e idade . . . . . . . . . . . . . . . . . . . . . . . 74 


\section{Lista de tabelas}

Tabela 1 - Objetivos e procedimentos metodológicos. . . . . . . . . . . 16

Tabela 2 - Competências Gerais. . . . . . . . . . . . . . 38

Tabela 3 - Competências específicas da área da Matemática. . . . . . . . . . . 43

Tabela 4 - As competências genéricas e específicas que facultaram origem ao metaperfil em cada uma das dimensões. . . . . . . . . . . . . . . . 45

Tabela 5 - Conteúdos mínimos de Matemática por área. . . . . . . . . . . . 47

Tabela 6 - Competências e Habilidades das DCN para os cursos de Matemática. . 52

Tabela 7 - Competências e Habilidades das DCN específicas do licenciado. . . . . 53

Tabela 8 - Equivalência entre as competências. . . . . . . . . . . . 54

Tabela 9 - Exemplos de similaridade entre o perfil do egresso do PPC e as competências das DCN e do Tuning. . . . . . . . . . . . . . . . . . . . . 64 


\section{Lista de abreviaturas e siglas}

CAPES Coordenação de Aperfeiçoamento de Pessoal de Nível Superior

CE Competência Específica do Projeto Tuning América Latina

CG Competência Geral do Projeto Tuning América Latina

CH Competência Geral das Diretrizes Curriculares Nacionais

CHE Competência Específica das Diretrizes Curriculares Nacionais

CLAR Crédito Latino-Americano de Referência

CNPq Conselho Nacional de Desenvolvimento Científico e Tecnológico

CNT Centros Nacionais Tuning

DCN Diretrizes Curriculares Nacionais

ECTS Sistema Europeu de Transferências e Acúmulo de Créditos

IFES Instituição Federal de Ensino Superior

LDB Lei de Diretrizes e Bases da Educação Nacional

PPC Projeto Pedagógico do Curso

RIACES Rede Ibero-americana para Acreditação da Qualidade da Educação Superior

TIC Tecnologias da Informação e Comunicação

Unesco Organização das Nações Unidas para a Educação, a Ciência e a Cultura

UEALC União Europeia, América Latina e o Caribe 


\section{Sumário}

Introdução $\ldots \ldots \ldots \ldots \ldots \ldots \ldots \ldots$

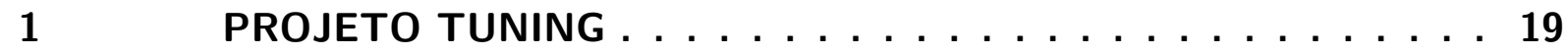

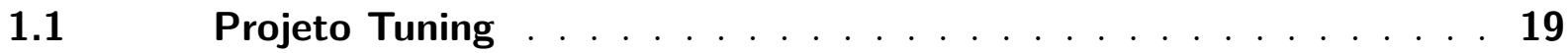

$1.2 \quad$ Projeto Tuning América Latina . . . . . . . . . . . . . 21

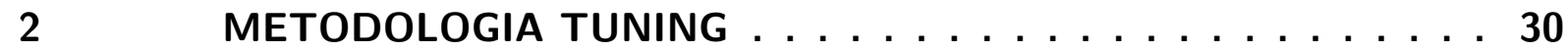

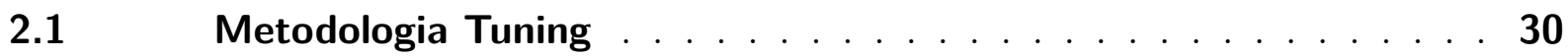

$2.2 \quad$ O Modelo Tuning . . . . . . . . . . . . . . . . . . . 31

2.3 ECTS (European Credit and Accumulation System) - Sistema Europeu de Transferência e Acúmulo de Créditos . . . . . . . . 32

2.3.1 O ECTS no contexto Latino americano . . . . . . . . . . . . . . 32

2.4 Resultados da aprendizagem e competências . . . . . . . . . 35

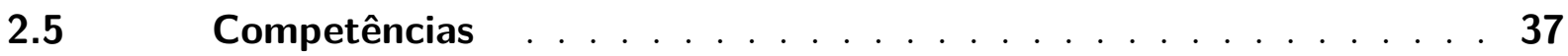

3 PROPOSTA DO PROJETO TUNING AMÉRICA LATINA NA ÁREA DA MATEMÁTICA . . . . . . . . . . . . . . 40

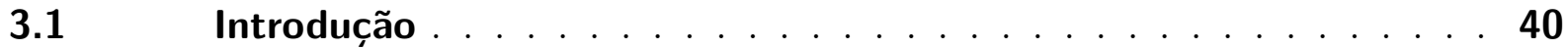

3.2 Competências Específicas na Matemática . . . . . . . . . . 42

3.3 Meta Perfil do graduado em Matemática . . . . . . . . . . . . . 44

3.4 Conteúdos Curriculares da área de Matemática . . . . . . . . . . . . 47

4 A RELAÇÃO DO PROJETO TUNING AMÉRICA LATINA COM AS DIRETRIZES CURRICULARES NACIONAIS PARA A LICENCIATURA EM MATEMÁTICA . . . . . . . . . . . . 49

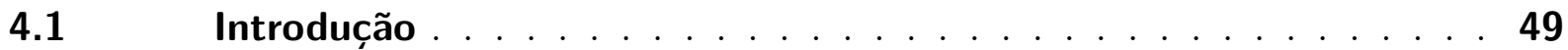

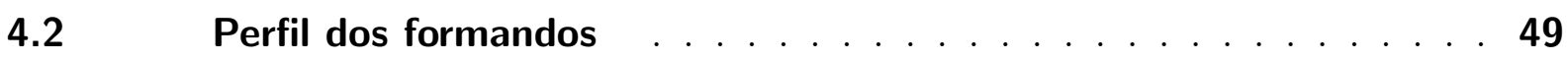

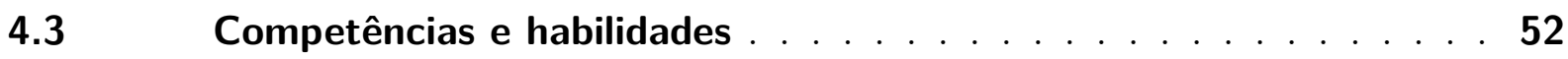

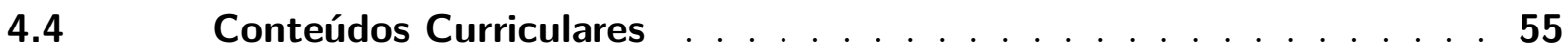

$4.5 \quad$ Carga horária do curso de Matemática . . . . . . . . . . . 57

5 ANÁLISE DE UM PROJETO PEDAGÓGICO DE UM CURSO DE LICENCIATURA EM MATEMÁTICA DE UMA INSTITUIÇÃO DE

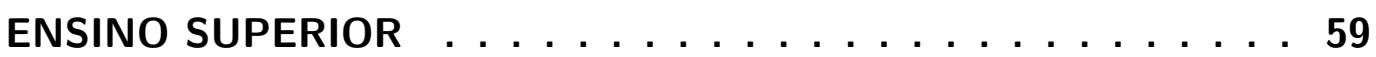

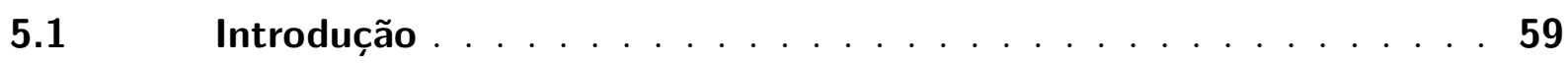

$5.2 \quad$ Perfil dos formandos . . . . . . . . . . . . . . 61

$5.3 \quad$ Competências Gerais e específicas . . . . . . . . . . . . . . . 64 
$5.4 \quad$ Conteúdos Curriculares . . . . . . . . . . . . . . . 65

$5.5 \quad$ Carga horária . . . . . . . . . . . . . . . . . . 666

$5.6 \quad$ Estágios . . . . . . . . . . . . . . . . . 68

$5.7 \quad$ Atividades Complementares . . . . . . . . . . . . . 68

6 ANÁLISE DAS RESPOSTAS DOS DOCENTES AO QUESTIONÁRIO . . . . . . . . . . . . . . . 70

$6.1 \quad$ Etapas da pesquisa . . . . . . . . . . . . . . . 70

$6.2 \quad$ Análise e discussão dos resultados . . . . . . . . . . . . . . . 71

7 CONSIDERAÇÕES FINAIS . . . . . . . . . . . 75

Referências ..................... . . 79

$\begin{array}{lll}\text { I } & \text { APÊNDICES } & 81\end{array}$

$\begin{array}{llr}\text { II } & \text { ANEXOS } & 85\end{array}$ 


\section{Introdução}

Almejar uma educação de qualidade em todos os níveis é projetar melhorias na educação superior. Se for cogitada a construção de projetos de futuro, a formação de professores para a educação básica deve ser tomada como uma ação legítima e necessária. Entre o turbilhão de dificuldades que hoje a educação está imersa, encontra-se a necessidade de articular o que ocorre no mundo internacional com os acontecimentos regionais e locais, de modo a auxiliar na construção da cidadania. Inserido nesse contexto dinâmico, a educação se vê obrigada a romper as fronteiras e se adequar às novas realidades.

Com o crescente processo da internacionalização ${ }^{1}$ da educação superior, o tema da qualidade do ensino ganha ainda mais força. O que entra em pauta na discussão é a manutenção da qualidade do ensino frente aos diferentes tipos de internacionalização. Esta representa a crescente atividade transfronteiriça, discutida em termos de mobilidade física, cooperação acadêmica e transferência de conhecimento acadêmico. Nessa linha de abordagem surge, em 2000, o Projeto Tuning, de âmbito internacional, ligado ao Tratado de Bolonha, visando à convergência do ensino superior na União Europeia. Trata-se de um projeto iniciado na Europa e expandido em 2003 para a América Latina, dando origem ao Tuning América Latina, que tem por finalidade a busca de consensos que orientem a progredir no desenvolvimento de titulações facilmente comparáveis e compreensíveis na América Latina.

Mesmo pouco conhecido, e em constante desenvolvimento, o projeto possui objetivos, competências e estrutura organizacional bem definidos, tendo como foco principal a formação por competências, sem perder a identidade cultural regional e a diversidade de cada país participante. O sistema do Tuning América Latina é centrado no aluno e busca favorecer o desenvolvimento de uma reforma curricular, embasada nas competências, com vistas a promover a mobilidade estudantil entre as universidades latinoamericanas a partir de um sistema compartilhado de reconhecimento do trabalho do aluno. (BENEITONE et al., 2007)

A cada dia e com uma velocidade cada vez mais intensa, novos conhecimentos são criados e a sociedade deve preparar-se para empregar esses avanços nos seus processos tecnológicos de forma eficiente e inovadora. Dessa maneira, as universidades precisam se manter continuamente atualizadas no que se refere aos conteúdos de seus programas acadêmicos, promovendo a harmonização dos estudos por meio de programas de estudo flexíveis. O aluno tem ao seu alcance novas formas de aprendizado, o que lhe permite alcançar seus objetivos por um caminho alternativo à via tradicional. O mercado de

$\overline{1}$ Mais sobre "Internacionalização" pode ser pesquisado em Van Damme (2001) 
trabalho vive em constante atualização e muito rapidamente os conhecimentos tornamse ultrapassados, havendo a necessidade de os alunos inserirem, em seus processos de ensino-aprendizado, competências que lhes concedam flexibilidade, autonomia e adaptação constante à mudança. A estrutura do sistema nacional de educação no Brasil não está imune às diversas influências do mundo moderno e, diante disso, algumas ações planejadas estão sendo feitas com o propósito de inserir a educação superior nos moldes do mundo contemporâneo. O Plano Nacional de Educação descreve na meta 12, estratégias 12.11 e 12.12, os objetivos:

Fomentar estudos e pesquisas que analisem a necessidade de articulação entre formação, currículo, pesquisa e mundo do trabalho, considerando as necessidades econômicas, sociais e culturais do País; Consolidar e ampliar programas e ações de incentivo à mobilidade estudantil e docente em cursos de graduação e pós-graduação, em âmbito nacional e internacional, tendo em vista o enriquecimento da formação de nível superior. (BRASIL, 2014)

Nesse contexto, percebe-se que a mudança que vem ocorrendo na educação brasileira direciona-se na mesma linha do Projeto Tuning. Dessa forma, é preciso verificar quão próximos estão alguns documentos específicos que regem a nossa educação, em particular as Diretrizes Curriculares Nacionais (DCN) para a Licenciatura em Matemática, com a proposta do projeto internacional Tuning América Latina na área da matemática.

Para compreender melhor o objeto em estudo, realizou-se, inicialmente, uma pesquisa bibliográfica que ofereceu meios para definir e conhecer a proposta do projeto Tuning.

Segundo Gil (2008, p. 50),

A pesquisa bibliográfica é desenvolvida a partir de material já elaborado, constituído principalmente de livros e artigos científicos. A principal vantagem da pesquisa bibliográfica reside no fato de permitir ao investigador a cobertura de uma gama de fenômenos muito mais ampla do que aquela que poderia pesquisar diretamente. O desenvolvimento da pesquisa documental segue os mesmos passos da pesquisa bibliográfica. Apenas há que se considerar que o primeiro passo consiste na exploração das fontes documentais, que são em grande número.

Explorando apenas os fatos relevantes ao estudo, faz-se uso da abordagem do pensamento de Bardin (2011, p.51):

A análise documental é uma operação ou um conjunto de operações visando representar o conteúdo de um documento sob uma forma diferente da original, a fim de facilitar, num estado ulterior, a sua consulta e referenciação.

Na perspectiva de Ludke e André (1986) "A análise documental busca identificar informações factuais nos documentos a partir de questões e hipóteses de interesse". 
Para analisar e verificar o grau de proximidade das DCN com o projeto Tuning América Latina é necessário, primeiramente, compreender a concepção e explicar a dinâmica de funcionamento do projeto Tuning América Latina na parte específica de matemática, visando levantar pontos suscetíveis à confluência com as DCN para a Licenciatura em Matemática.

A análise documental sinalizou diferenças e similaridades entre as DCN para a Licenciatura em Matemática e o Tuning América Latina na área da matemática. Dessa maneira, a presente pesquisa foi estruturada com o objetivo geral:

\section{Objetivo Geral}

- Analisar a convergência do Projeto Tuning América Latina na área de matemática com as Diretrizes Curriculares Nacionais dos cursos de Matemática.

O desdobramento deste objetivo geral resultou nos seguintes objetivos específicos:

\section{Objetivos Específicos}

- Descrever as propostas e os objetivos do Projeto Tuning América Latina;

- Identificar as relações e perspectivas do Projeto Tuning na área da Matemática;

- Estudar a relação entre o Projeto Tuning América Latina e as Diretrizes Curriculares Nacionais para os cursos de Matemática;

- Verificar a proximidade das propostas do Projeto Tuning América Latina com o Projeto Pedagógico do curso de Matemática de uma Instituição Federal de Ensino Superior (IFES);

- Identificar o grau de conhecimento dos docentes de matemática da IFES pesquisada acerca das DCN da área e do Projeto Tuning.

O objetivo geral e os objetivos específicos foram inseridos em um quadro conjuntamente com os procedimentos metodológicos adotados para o cumprimento dos mesmos (ver Tabela 1).

A pesquisa bibliográfica e documental foi um dos pilares metodológicos do trabalho, objetivando, primeiramente, a construção do conhecimento teórico necessário à compreensão do tema em estudo.

A pesquisa bibliográfica resultou nos três primeiros capítulos, desenvolvidos seguindo a mesma linha de planejamento. O capítulo I é inteiramente destinado a apresentar a estrutura do Projeto Tuning, tendo como base os livros do projeto. Foi estruturado buscando-se, na bibliografia, informações pertinentes à análise desejada para situar o leitor desde o surgimento do projeto até a expansão e criação do Tuning América Latina, seus objetivos, as linhas de trabalho, os resultados já alcançados até os ainda almejados. No capítulo II, apresenta-se a metodologia Tuning, a ideia inovadora do Crédito Latino- 
Tabela 1 - Objetivos e procedimentos metodológicos.

\begin{tabular}{|c|c|}
\hline Objetivo Geral: & $\begin{array}{l}\text { Analisar a convergência do Projeto Tuning América } \\
\text { Latina na área de matemática com as Diretrizes Curri- } \\
\text { culares Nacionais dos cursos de Matemática. }\end{array}$ \\
\hline Objetivo específico & Procedimento metodológico \\
\hline $\begin{array}{l}\text { Descrever as propostas e os objetivos do } \\
\text { Projeto Tuning América Latina; }\end{array}$ & $\begin{array}{l}\text { Análise documental e de conteúdo: estudo do material } \\
\text { bibliográfico sobre o Projeto Tunig desde o surgimento } \\
\text { até a expansão para outros continentes, extraindo pontos } \\
\text { relevantes como a estrutura organizacional, os países } \\
\text { participantes, os objetivos e as competências gerais, } \\
\text { organizadas com notações específicas em tabela. }\end{array}$ \\
\hline $\begin{array}{l}\text { Identificar as relações e perspectivas do } \\
\text { Projeto Tuning na área da Matemática; }\end{array}$ & $\begin{array}{l}\text { Análise documental e de conteúdo: estudo do material } \\
\text { bibliográfico sobre a organização da área da matemá- } \\
\text { tica no projeto Tunig América Latina, organização das } \\
\text { competências específicas da área em tabela, análise da } \\
\text { construção do meta-perfil a partir de quatro dimensões } \\
\text { que o matemático deve alcançar. }\end{array}$ \\
\hline $\begin{array}{l}\text { Estudar a relação entre o Projeto Tuning } \\
\text { América Latina e as Diretrizes Curriculares } \\
\text { Nacionais para os cursos de Matemática; }\end{array}$ & $\begin{array}{l}\text { Análise documental e de conteúdo: estudo das DCN } \\
\text { para os cursos de matemática (Parecer nº1302/2001) e } \\
\text { documentos relacionados, identificando pontos relevan- } \\
\text { tes para a comparação: perfil, conteúdo, competências } \\
\text { (organizadas em tabela com notação), comparação en- } \\
\text { tre as informações da análise documental do Tuning } \\
\text { América Latina e das DCN. }\end{array}$ \\
\hline $\begin{array}{l}\text { Verificar a proximidade das propostas do } \\
\text { Projeto Tuning América Latina com o Pro- } \\
\text { jeto Pedagógico do curso de Matemática de } \\
\text { uma instituição federal de ensino superior } \\
\text { (IFES); }\end{array}$ & $\begin{array}{l}\text { Análise documental e de conteúdo: estudo do PPC de } \\
\text { uma IFES e documentos relacionados. Comparação en- } \\
\text { tre as informações da análise documental do Tuning } \\
\text { América Latina e do PPC. }\end{array}$ \\
\hline $\begin{array}{l}\text { Identificar o grau de conhecimento dos do- } \\
\text { centes de matemática da IFES pesquisada } \\
\text { acerca das DCN da área e do Projeto Tu- } \\
\text { ning. }\end{array}$ & $\begin{array}{l}\text { Pesquisa de caráter descritivo: aplicação de um questio- } \\
\text { nário a docentes de uma IFES com perguntas semies- } \\
\text { truturadas. Análise dos dados obtidos e interpretação } \\
\text { dos resultados. }\end{array}$ \\
\hline
\end{tabular}

Fonte: Próprio autor.

americano de Referência - CLAR e as competências gerais, essas, colocadas em tabela para facilitar a referência ao longo do trabalho. O capítulo III segue trazendo a proposta do Tuning América Latina para a área da matemática, o meta-perfil, as competências específicas e os conteúdos da área, organizados em tabela para auxiliar na referenciação. 
Segundo Bardin (2011, p.51)

\begin{abstract}
Enquanto tratamento da informação contida nos documentos acumulados, a análise documental tem por objetivo dar forma conveniente e representar de outro modo essa informação, por intermédio de procedimentos de transformação. O propósito a atingir é o armazenamento sob uma forma variável e a facilitação do acesso ao observador, de tal forma que este obtenha o máximo de informação (aspecto quantitativo), com o máximo de pertinência (aspecto qualitativo).
\end{abstract}

Na sequência, foi desenvolvida a pesquisa documental das DCN, analisando-se os seguintes documentos: Parecer CNE/CES 1302/2001 (BRASIL, 2001a) e as Resoluções CNE/CES 3/2003 (BRASIL, 2003) e CNE/CP 2/2002 (BRASIL, 2002b). Partiu-se, então, para a análise das informações com o intuito de se estabelecer as conexões e as relações entre as partes, investigando as similaridades e diferenças entre as DCN e o Tuning América Latina para a área da matemática. Após a identificação das competências equivalentes, foi elaborada uma tabela de equivalência com a finalidade de organizar as informações levantadas.

No quinto capítulo, foi feito o estudo do Projeto Pedagógico do Curso (PPC) da Licenciatura em Matemática de uma IFES e, além dos documentos do capítulo anterior, a Lei 9394/1996 (BRASIL, 1996), o Parecer CNE/CP 09/2001 (BRASIL, 2001b) e a Resolução CNE/CP 1/2002 (BRASIL, 2002a). Continuando na mesma linha de trabalho e organização dos dados, buscaram-se relações de convergências entre o PPC investigado com as propostas do Tuning América Latina, explanando-se as divergências encontradas.

Com o objetivo de detectar o nível de disseminação do Projeto Tuning América Latina no meio acadêmico, foi aplicado um questionário a docentes de uma IFES, escolhida por conveniência. O questionário também investigou o nível de conhecimento que eles têm acerca das Diretrizes Curriculares Nacionais para os cursos de matemática. Essa pesquisa teve caráter descritivo, de acordo com Gil (2008, p.28)

\footnotetext{
As pesquisas descritivas têm como objetivo primordial a descrição das características de determinada população ou fenômeno ou o estabelecimento de relações entre variáveis [...]. Dentre as pesquisas descritivas, salientam-se aquelas que têm por objetivo estudar as características de um grupo [...]. São incluídas neste grupo as pesquisas que têm por objetivo levantar as opiniões, atitudes e crenças de uma população.
}

A coleta de dados da pesquisa foi realizada por intermédio de um questionário objetivo, limitado em nove perguntas e acompanhado das instruções esclarecedoras do propósito de sua aplicação, ressaltando-se a importância da colaboração do docente na pesquisa. Para o bom êxito do estudo e obtenção de uma amostragem significativa, foi preciso paciência e persistência, para atingir um terço do universo de professores da 
IFES, na respectiva unidade acadêmica de oferta do curso. A pesquisa se delineou por levantamento de campo, segundo Gil (2008, p.55)

As pesquisas deste tipo se caracterizam pela interrogação direta das pessoas cujo comportamento se deseja conhecer. Basicamente, procede-se à solicitação de informações a um grupo significativo de pessoas acerca do problema estudado para em seguida, mediante análise quantitativa, obter as conclusões correspondentes dos dados coletados.

Os dados da pesquisa foram organizados por meio de recursos manuais, analisados, interpretados, dando origem ao capítulo 6. Todas as informações foram dispostas em gráficos e extremamente enriquecedoras ao estudo, explicitando o objetivo da pesquisa.

Paralelamente a tudo isso, realizou-se uma entrevista com uma das coordenadoras do Projeto Tuning América Latina no Brasil, a professora Loussia Felix. A entrevista foi contextualizada para que a entrevistada ficasse a par do propósito do estudo. Como afirma Richardson (1999, p.216) "toda entrevista precisa de uma introdução, que consiste, essencialmente, nas devidas explicações e solicitações exigidas por qualquer diálogo respeitoso". Um roteiro de entrevista foi feito previamente buscando-se reunir, em um menor número de perguntas, a maior quantidade de informações. Durante a entrevista, com a devida autorização da entrevistada, um gravador foi utilizado para possibilitar os registros de forma mais adequada e fidedigna possível. De acordo com o que afirma May (2004, p.164), o uso de gravador é justificável, "pois permite que o entrevistador concentre-se na conversa e registre os gestos não verbais do entrevistado durante a entrevista". Os dados coletados na entrevista contribuiram todo o estudo e foram incluídos na extensão do trabalho com falas de confirmação e complementação das informações contidas. 


\title{
1 Projeto Tuning
}

\subsection{Projeto Tuning}

Lema Tuning: Harmonização das estruturas e programas educacionais respeitando sua diversidade e autonomia.

O Projeto Tuning surgiu da necessidade da criação do espaço europeu de educação superior e, teve início no ano de 2000 como um projeto ligado ao Tratado de Bolonha, firmado em 1999 entre alguns países europeus, na cidade de Bolonha na Itália, visando à convergência do ensino superior na União Europeia.

Em termos musicais, tuning é traduzido como "afinação", assim pode-se entender o projeto Tuning como um "alinhamento" das propostas educacionais existentes nas universidades com as linhas de ação acordadas no Tratado de Bolonha. Esse projeto propiciou um espaço de liberdade para afinar, conciliar as estruturas educacionais pensadas na reestruturação curricular baseada em competências, com o olhar focado no aluno, tornando-o segmento ativo e integrante do processo de aprendizado. Esse acorde no âmbito das titulações permitiria compreender, comparar e reconhecê-las no espaço europeu de educação superior. (BENEITONE et al., 2007)

Uma definição precisa para Tuning é dada por Beneitone et al. (2007, p.323):

\begin{abstract}
Em inglês, tune significa sintonizar uma determinada frequência na rádio; também se utiliza para descrever o processo de afinar os distintos instrumentos de uma orquestra, de modo que, os intérpretes possam tocar a música sem dissonâncias. No caso do Projeto Tuning, significa consensuar pontos de referência para organizar as estruturas da educação superior na Europa, sem deixar de reconhecer que a diversidade das tradições é um fator positivo na criação de uma área de ensino superior comum e dinâmica.
\end{abstract}

Como bem resume Pablo Beneitone, Julia González e Robert Wagenaar ${ }^{1}$, o projeto Tuning é uma rede de comunidades de aprendizado formada por acadêmicos e estudantes que refletem, debatem, elaboram instrumentos e partilham resultados. Esses especialistas trabalham em grupos internacionais e interculturais, respeitando a autonomia institucional, nacional e regional, trocando conhecimentos e experiências.

A metodologia Tuning é dinâmica, tem etapas bem programadas ajustáveis aos contextos diferentes com um único objetivo: criar cursos e diplomas compatíveis, com-

1 Pablo Beneitone(Diretor do Tuning), Julia González e Robert Wagenaar (Coordenadores Gerais do Projeto Tuning) 
paráveis, com qualidade e excelência sendo útil a sociedade e respeitando as tradições e diversidade de cada país. (VILLA et al., 2014)

Segundo documentos, o Tuning é um projeto em contínuo desenvolvimento iniciado por instituições européias de ensino superior, se expandiu por quase todos os continentes. Atualmente Tuning alça voos que vão além do projeto e assume um papel de metodologia reconhecida internacionalmente, um instrumento construído para e em prol das universidades alcançando o então sonhado Espaço de Ensino superior Europeu.

Na Europa o projeto conta hoje com 33 países participantes e instituições espalhadas por quase toda a Europa. Atualmente o Tuning se encontra disseminado por outros continentes sua expansão já atingiu África, China, Rússia e América Latina, conforme consta no site ${ }^{2}$ oficial do projeto.

Figura 1 - Estrutura da Educação Tuning na Europa.

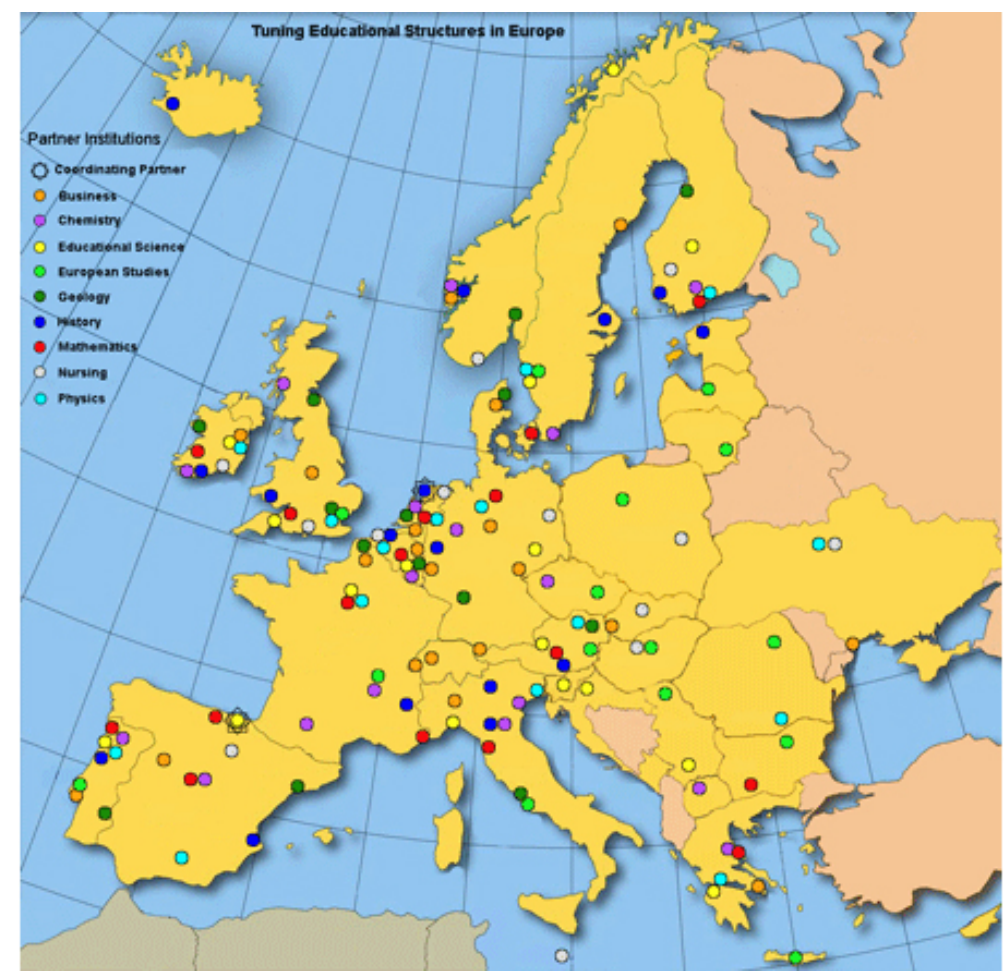

Fonte: Site oficial do projeto.

Em 2002, durante a IV Reunião de Seguimento do Espaço Comum de Ensino Superior da União Europeia, América Latina e o Caribe (UEALC) na cidade de Córdoba, na Espanha, participantes latino-americanos presentes na reunião viram a possibilidade de estender a experiência para a América Latina após ver os resultados da primeira fase do Tuning Europa, desde então se iniciou os trabalhos e no final de outubro de 2003 representantes da América Latina e um grupo de universidades europeias apresentaram a 2 Site oficial do Projeto Tuning: <http://www.unideusto.org/tuningeu/home.html> 
proposta ao Programa Alfa ${ }^{3}$, surgindo assim o Tuning América Latina.

\subsection{Projeto Tuning América Latina}

Em 2003, a proposta inicial do Projeto Tuning América Latina foi apresentada por 15 universidades sendo 8 latino-americanas e 7 europeias.

Entre julho e agosto de 2004, dezoito países latino-americanos foram visitados pelos coordenadores gerais do Tuning para explicar, dialogar e reajustar a proposta com os Ministérios de Educação, Conferências de Reitores e instâncias decisórias dos diferentes países, em matéria de ensino superior. As sugestões recebidas foram consideradas e incorporadas ao projeto latino-americano que começou formalmente em outubro de 2004. (Beneitone et al. (2007))

Entende-se, assim, que a proposta Tuning para a América Latina se beneficiou das ideias acadêmicas oriundas da Europa, mas foram trabalhadas e pensadas por latinoamericanos buscando uma ideia única e intercontinental adaptada a uma nova realidade, como confirmado pela professora entrevistada "desde a sua base, o projeto foi construído pela equipe latinoamericana, as competências, o meta-perfil, as metodologias, tudo de maneira livre, sem interferências ou imposições".

Na primeira fase (2004-2007), o grande objetivo do projeto foi promover um debate a fim de identificar e trocar informações, além de aperfeiçoar a cooperação entre as instituições de ensino superior para o desenvolvimento da qualidade, eficiência e transparência dos programas e cursos da região. (VILLA et al., 2014) e (BENEITONE et al., 2007).

O Projeto Tuning América Latina é financiado pela União Europeia, desde a execução e organização das reuniões de trabalho até a publicação dos resultados, o que inclui diárias, deslocamentos dos participantes, elaboração de documentos de debates, tudo garantido pelo denominado Programa Alfa.

Há um grande interesse por parte das universidades europeias em conhecer qual seria o grau de correlação dos resultados obtidos na Europa com os que foram alcançados na América Latina, isso porque os resultados das discussões viabilizariam, no futuro, propostas de acordo internacionais acerca das titulações.

Gerado como um espaço de reflexão, o Tuning América Latina vai à busca de consensos que orientem a progredir no desenvolvimento de titulações facilmente comparáveis e compreensíveis na America Latina, de maneira articulada.

3 Programa Alfa: <http://www.uc.pt/fduc/servicos/gric/programa_alfa/print> 
"É um projeto aberto a reflexão permanente, em andamento e sempre permeável à incorporação de novos países, que enriqueçam e modifiquem a proposta inicial. Isto é o que se entende por cooperação no Tuning: estar aberto ao diálogo e aprendizado mútuo". (BENEITONE et al., 2007, p.13)

Criado pelas universidades e para as universidades, começou seus trabalhos com 62 universidades latino-americanas debatendo quatro áreas do conhecimento: Administração de Empresas, Educação, História e Matemática. Com os trabalhos em andamentos nos 18 países participantes e a dimensão que o Tuning América Latina estava tomando, 120 novas universidades foram agregadas e, agora, o projeto engloba 12 áreas temáticas: Administração de Empresas, Arquitetura, Direito, Educação, Enfermagem, Engenharia, Física, Geologia, História, Matemática, Medicina e Química. Atualmente o Tuning América Latina é composto por 18 países participantes: Argentina, Bolívia, Brasil, Chile, Colômbia, Costa Rica, Cuba, Equador, El Salvador, Guatemala, Honduras, México, Nicarágua, Panamá, Paraguai, Peru, Uruguai e Venezuela. No material impresso relativo ao projeto constam as doze áreas temáticas listadas acima, entretanto no site oficial do Projeto Tuning já foram incluídas quatro novas áreas temáticas que compõem na fase atual: agronomia, informática, psicologia e inovação social, sendo que a última não é considerada área temática e sim grupo de trabalho. A Figura 2 ilustra a distribuição das áreas temáticas.

Quanto às instituições, os responsáveis pela seleção das universidades participantes do projeto foram os Ministérios de Educação, Conselhos de Ensino Superior e/ou Conferências de Reitores de cada um dos países latino-americano, levando em consideração a trajetória, autoridade e tamanho da instituição acadêmica, bem como a excelência nacional na área que representam e predisposição ao diálogo com outras instituições que trabalham na mesma disciplina, de maneira tal que o sistema de ensino superior de cada país esteja bem representado pelas instituições escolhidas.

A República Dominicana é um país não elegível na Convocatória do Programa Alfa, razão pela qual não foi incluída no grupo dos 18 países latino-americano iniciais, mas solicitou formalmente juntar-se ao projeto, assumindo inteiramente os custos da sua participação. Desta forma, o projeto conta com a cobertura em 19 países e em 190 universidades latino-americanas comprometidas com o trabalho apresentado. (BENEITONE et al., 2007, p.17)

A estrutura organizacional é bastante dinâmica, possui um Comitê de Gestão, quinze grupos de trabalho (um para cada área temática) e 18 Centros Nacionais trabalhando em conjunto. Cada um dos Centros Nacionais Tuning (CNT) é formado pelos representantes das instâncias máximas das políticas universitárias de cada país participante, funciona como uma conexão entre o projeto e o país, como definido por Beneitone et al. (2007, p.320). 
Figura 2 - Distribuição das áreas temáticas.

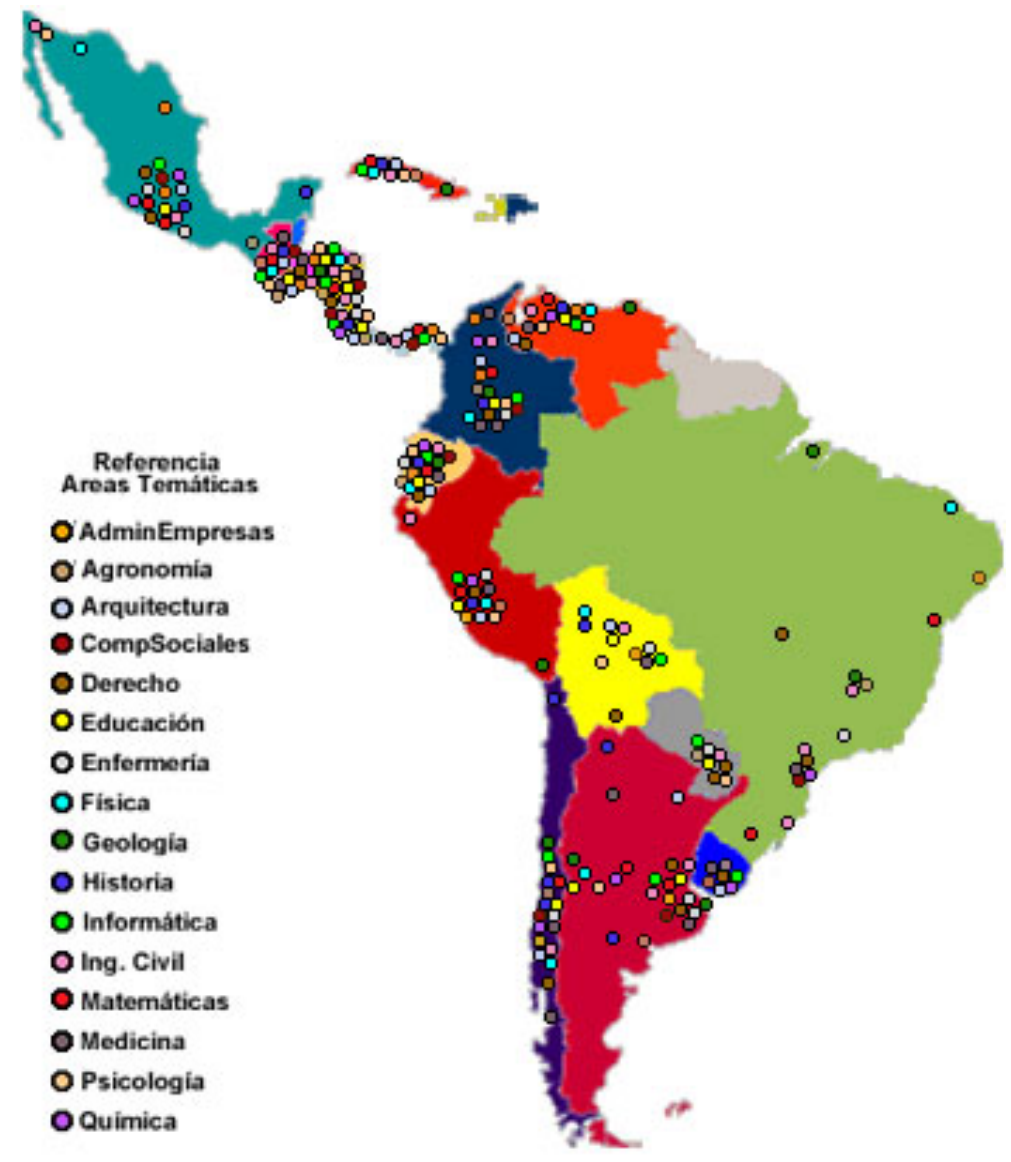

Fonte:<http://www.tuningal.org/es/participantes>, acessado em 01/2015

O Centro Nacional Tuning é uma figura criada dentro do Projeto Alfa Tuning América Latina, que tem por objetivos principais acompanhar as atividades das universidades participantes do Projeto e difundir os resultados alcançados, entre as instituições e organismos de ensino superior de seu país. Cada país participante do Projeto conta com um CNT, o qual é o elo de ligação entre o projeto e seu país. A Figura 3 representa a estrutura organizacional do Projeto Tuning América Latina.

Com essa representatividade pelos CNT cada um dos 19 países participa no projeto de forma igualitária, colaborando no desenvolvimento da metodologia, no entanto são as universidades os personagens principais nesse processo. Os CNT acompanham as instituições inserindo as contribuições de todos os participantes que compõem seu sistema nacional.

Para que o projeto fosse executado e propagado nos diversos países da América Latina o papel dos CNT foi extremamente significativo. O compromisso e a participação dos responsáveis de política universitária nos trabalhos desenvolvidos assinala um marco no desenvolvimento de projetos de pesquisa das características do Tuning. O impacto do projeto no sistema latino americano está relacionado tanto ao bom trabalho das universi- 
Figura 3 - Estrutura organizacional do projeto Tuning na América Latina.

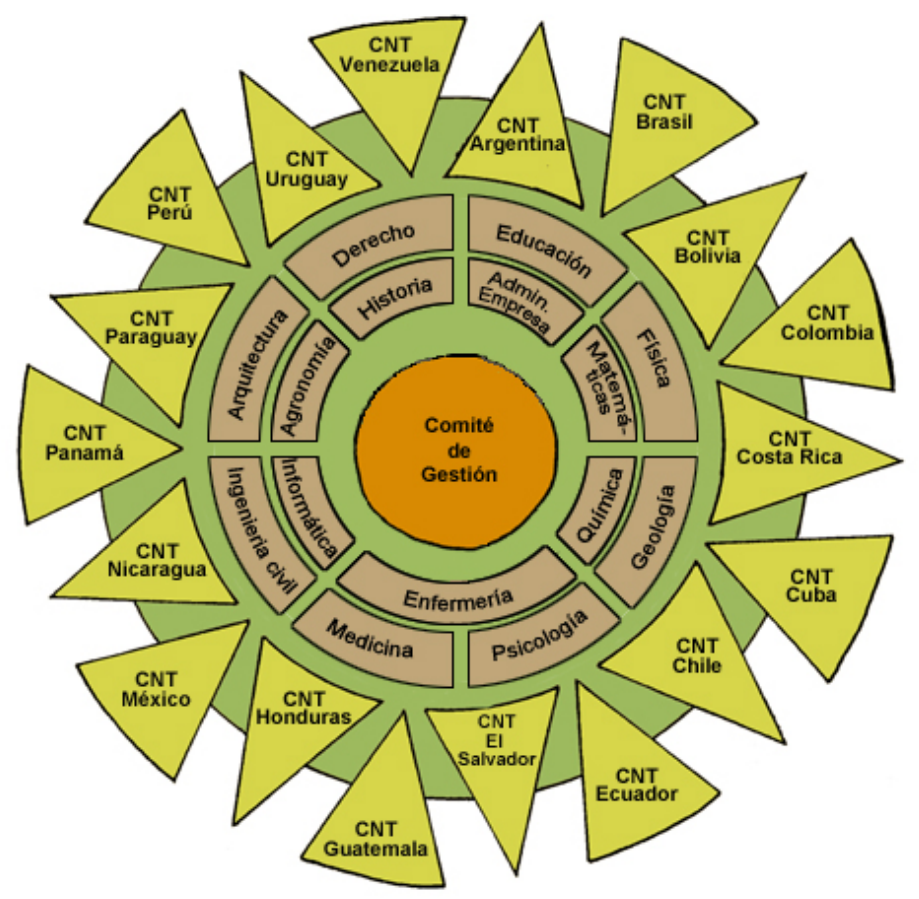

Fonte:<http://www.tuningal.org/es/participantes>, acessado em 01/2015.

dades quanto ao acompanhamento das instâncias de política universitária, representada pelos CNT. Considerado a grande contribuição da América Latina para o projeto Tuning, os CNT trabalham contextualizando os debates, assumindo e adaptando os resultados às necessidades locais. (Beneitone et al. (2007) e Villa et al. (2014)).

No desenrolar do projeto reuniões gerais são realizadas para compartilhar resultados e dúvidas, materiais de debates e reflexões anteriormente acordados. Em cada reunião um documento ${ }^{4}$ é redigido com os trabalhos dos encontros anteriores que estão em consenso. Assim experiências são adquiridas e compartilhadas pelas instituições e acadêmicos latinoamericanos contribuindo expressivamente para o desenvolvimento de linguagens comuns que possam auxiliar no progresso de todos como sociedade.

Pode-se dizer que a universidade é o centro dos debates, da inovação, da cultura e do pensamento, contudo, deve estar convencida da necessidade de manter-se em harmonia com a realidade à sua volta bem como com os novos paradigmas do ensino superior.

Novas tendências universais de ensino superior são assumidas pela universidade latino-americana como bem sintetiza Beneitone et al. (2007). Em primeiro, lugar encontrase o desenvolvimento econômico e social que se caracteriza pela incorporação de um novo fator produtivo baseado no conhecimento e no gerenciamento apropriado da informação. A

4 Todos os documentos estão publicados na página do projeto Tuning América latina <http://tuning. unideusto.org/tuningal/> 
cada dia e com uma velocidade cada vez mais intensa, novos conhecimentos são criados e as sociedades devem preparar-se para empregar esses avanços nos seus processos tecnológicos de forma eficiente e inovadora. Dessa maneira, as universidades precisam se manter continuamente atualizadas no que se refere aos conteúdos de seus programas acadêmicos, promovendo a harmonização dos estudos por meio de programas de estudo flexíveis. O aluno tem ao seu alcance novas formas de aprendizado, o que lhe permite alcançar seus objetivos por um caminho alternativo à via tradicional. $\mathrm{O}$ mercado de trabalho vive em constante atualização e muito rapidamente os conhecimentos tornam-se ultrapassados, havendo a necessidade de os alunos inserirem em seus processos de ensino-aprendizado, competências que lhes concedam flexibilidade, autonomia e adaptação constante à mudança.

A segunda tendência está associada às novas TIC (tecnologias da informação e comunicação), que provocaram a aceleração e modificação dos processos de gerenciamento da informação e das comunicações. Com a incorporação das TIC $^{5}$ novas mudanças são necessárias até mesmo no papel tradicional do aluno e do professor no ensino superior. As tecnologias da informação e comunicação quando inseridas no ensino superior devem vir para melhorar a qualidade do ensino, dinamizar, acelerar e desenvolver alternativas pedagógicas e metodológicas que substituam ou ao menos enriqueçam as práticas tradicionais, sendo ferramentas para o processo de ensino-aprendizado, não se esquecendo de que a educação parte de um processo pedagógico e não tecnológico. Contudo, essa integração só será real quando se demonstrar sua eficácia na formação dos professores, no aprendizado dos alunos, na melhora da relação professor aluno e em todas as atividades acadêmicas das diversas áreas e matérias universitárias.

Como consequência do avanço do conhecimento e das ferramentas existentes surge a terceira tendência universal: o novo perfil profissional. Diante desse quadro dinâmico de mudanças, novos cursos são criados, outros desaparecem naturalmente e os que permanecem precisam redefinir o novo perfil profissional de formação dos seus estudantes. Hoje a sociedade exige profissionais críticos, que conheçam a realidade mundial e local, compromissados etnicamente com as temáticas da sustentabilidade, da inclusão social, da diversidade, entre outras. Os perfis profissionais universitários devem ser projetados de acordo com as necessidades das regiões e do país, definidos a partir de um conjunto de competências a serem desenvolvidas ao longo da formação.

A quarta tendência da educação atual ocorre no processo de ensino-aprendizado. O aluno passa a ser o centro e o professor torna-se um mediador, que disponibiliza a ele informação, métodos, ferramentas e um ambiente propício para que desenvolva o seu próprio aprendizado. Nas palavras da entrevistada, "O estudante tem que ser motivado, ele precisa entender que é o sujeito ativo do processo de educação, ele é o sujeito transformação do processo e todo o processo é dirigido a ele".

5 Referências sobre esse tema podem ser buscadas em Coelho (1986). 
Por fim, tem-se a globalização, o alcance global das atividades humanas no âmbito do ensino superior. É cada vez mais frequente que universidades compartilhem cursos, programas de estudo e currículos com outras universidades, que ofertem dupla titulação que mantenham programas de mobilidade de professores e alunos, projetos de pesquisa em comum, tudo isso nos aponta para uma internacionalização do ensino superior. Pode-se pensar que a globalização conduz à transformação das universidades, principalmente com relação aos programas de pesquisa, parâmetros de avaliação e credenciamento. Entre outras coisas que se deseja é potencializar o intercâmbio de informação, de experiências, de professores e alunos, de incontestáveis vantagens, sem contar a igualdade ao acesso a programas de educação universitária através das novas tecnologias. Com isso alunos de qualquer continente podem matricular e cursar estudos universitários no seu lugar de origem.

Diante dessas novas tendências universais, as universidades precisam de uma estrutura e organização flexíveis, fazendo uso das novas tecnologias de informação e comunicação e, principalmente, inserindo métodos de segurança da qualidade.

Com base nas informações trazidas nas reuniões dos CNT e por formulários preenchidos pelos representantes dos países, algumas características dos sistemas de ensino superior na América Latina foram analisadas, entres outras características destaca-se, o crescimento do número de alunos matriculados no ensino superior, a maior participação feminina, o crescimento exorbitante das instituições privadas, além disso, foram levantados dados a respeito da organização dos períodos acadêmicos, a regulamentação do ensino superior, a oferta de programas de ensino com modalidade não presenciais. Diante deste contexto de transformação o Projeto Tuning surge como uma alternativa para as universidades latino-americanas, através de um trabalho coletivo, apresenta processos de ensino aprendizado respeitando a autonomia, diversidade e cultura acadêmica de cada região. Por essa razão, a experiência do Projeto Tuning possui temas de interesse comum, tais como:

- Um sistema centrado no aluno e baseado em competências.

- Novos paradigmas no campo educacional

- O reconhecimento de titulações entre os países latino-americanos.

- A construção conjunta de um espaço para dialogar sobre ensino superior com um olhar centrado na qualidade e buscando soluções concretas e acessíveis a problemas compartilhados. (BENEITONE et al., 2007)

Vale lembrar que o Tuning América Latina é um projeto e, portanto possui objetivos, resultados e um contexto específico. Na primeira fase do projeto 2004 - 2007 o foco inicial estava em promover um debate cujas discussões levassem a identificar e intercambiar informações e aperfeiçoar a cooperação entre as instituições de ensino superior com a finalidade do desenvolvimento da qualidade, eficiência e transparência dos programas 
de ensino, preservando a diversidade do ensino superior latino-americano e a autonomia universitária. (BENEITONE et al., 2007)

Um dos principais objetivos desta fase foi a contribuição para o desenvolvimento de titulações facilmente comparáveis e compreensíveis, a meta era impulsionar consensos regionais buscando compreender os títulos sobre o ângulo das competências adquiridas. Criase então uma busca por pontos comuns de referência, tendo como centro as competências.

Identificar competências gerais, que possam ser aplicadas a qualquer titulação, e também as competências específicas, aquelas relacionadas às áreas temáticas é a primeira entre as quatro grandes linhas de trabalho do Tuning América Latina. O Relatório Final de 2007 traz as quatro linhas de trabalho do Tuning América Latina:

1. Competências gerais e específicas;

2. Enfoques de ensino, aprendizado e avaliação destas competências;

3. Créditos acadêmicos;

4. Qualidade dos programas.

A primeira linha de trabalho está vinculada a definição e identificação das competências gerais, aquelas comuns a praticamente ou a todas as carreiras do ensino superior, tais como, a capacidade de aprender e atualizar-se permanentemente, a habilidade na utilização das tecnologias da informação e da comunicação, entre outras e que sejam relevantes a certos grupos sociais. Além das competências compartilhadas têm-se as competências específicas, são aquelas referentes às áreas temáticas, vinculadas a uma determinada disciplina, trazem autenticidade ao programa específico. A seleção das competências consideradas apropriadas a determinada região é de responsabilidade dos acadêmicos, mas abertos a ouvir grupos de interesse no tema. Ao determinar as competências, tanto gerais quanto específicas se estabelece pontos consensuais que firmam como pilares no desenvolvimento da qualidade e colaboram com os métodos de avaliação nacional e internacional.

A segunda linha procura de uma maneira apropriada aprender, ensinar e avaliar com o intuito de alcançar efetivamente os resultados da aprendizagem e das competências identificadas na linha de trabalho anterior. Isso significa desenvolver sob uma nova visão, uma combinação de enfoques de ensino e aprendizado, para incentivar o desenvolvimento das competências.

A terceira linha de trabalho do Tuning América Latina visa refletir sobre a relação entre o sistema de competências e o trabalho do aluno, a sua ligação e medida com o tempo calculado em créditos acadêmicos. Os créditos acadêmicos serão explicados no capítulo 2 , seção 2.3 .

Na quarta e última linha do projeto temos a qualidade dos programas. Vista como parte integrante da estrutura do currículo baseado em competências, o Tuning América 
Latina foi elaborado com vários elementos visando à qualidade do mesmo.

\begin{abstract}
"A confiança mútua entre as instituições de ensino superior e o reconhecimento das titulações que estas conferem deve ter como apoio básico uma metodologia comum e comparada de avaliação da qualidade. A mobilidade e o reconhecimento de estudos requerem um clima de confiança e de transparência e também uma correspondência comprovada entre os elementos fundamentais da formação, nos diferentes sistemas de ensino superior". (BENEITONE et al., 2007)
\end{abstract}

Concluída a primeira fase, o Tuning América Latina entra na sua nova fase (2011 2013) levando adiante os frutos dos debates e consensos da fase anterior(2004-2007). Nessa nova etapa do Tuning América Latina o objetivo principal é contribuir com a criação de um Espaço de Ensino Superior a partir da convergência curricular. Nesse desafio compreende quatro eixos bem determinados: aprofundar os acordos de elaboração dos meta-perfis das áreas temáticas do projeto; contribuir com a reflexão sobre cenários futuros para as novas profissões; promover a criação de estratégias metodológicas para desenvolver e avaliar a formação das competências; criar um sistema de créditos acadêmicos de referência(CLAR). (PANIAGUA et al., 2014)

Essa etapa do projeto se firmou com base nos acordos alcançados entre as universidades e governos participantes da primeira etapa. O site oficial do projeto detalha os setes objetivos do Tuning América Latina 2011 - 2013:

1. Avançar nos processos de reforma curricular com base em um enfoque sobre competências na América Latina, completando a metodologia Tuning.

2. Aprofundar o eixo de empregabilidade do projeto Tuning, desenvolvendo perfis de egresso vinculados às novas demandas e necessidades sociais, construindo as bases de um sistema hormônico que consiga desenhar esse enfoque de aproximação entre as diplomações.

3. Explorar novos desenvolvimentos e experiências em torno da inovação social universitária, e particularmente em relação ao eixo de cidadania do projeto Tuning.

4. Incorporar processos e iniciativas já implementadas em outros contextos para a construção de quadros disciplinares e setoriais para a América Latina.

5. Promover a construção conjunta de estratégias metodológicas para desenvolver e avaliar a formação de competências na implementação dos currículos que contribuam para melhorar continuamente a qualidade, incorporando níveis e indicadores.

6. Desenhar um sistema de créditos acadêmicos, tanto para a transferência quanto para a acumulação, facilitando assim o reconhecimento de estudos na América Latina como região, e possibilitando ainda a articulação com os sistemas de outras regiões.

7. Fortalecer os processos de cooperação regional favoráveis às iniciativas de reformas 
curriculares, aproveitando as capacidades e experiências dos diferentes países da América Latina.

Segundo o Relatório Final de 2007 (BENEITONE et al., 2007), o Tuning América Latina vai além das expectativas e consegue alcançar os noves resultados previstos:

1. Acordos gerais sobre a elaboração dos perfis acadêmico-profissionais das diplomações, baseados nas competências e resultados do aprendizado nas quinze áreas temáticas envolvidas no projeto.

2. Propostas de quadros disciplinares sobre as competências para quatro setores (Saúde, Engenharia, Ciências Naturais e Exatas, Ciências Sociais, e Humanidades) elaboradas a partir das 15 áreas temáticas trabalhadas.

3. Proposta de um sistema de análise para antecipar as novas profissões emergentes na sociedade, além das novas competências requeridas para esses casos.

4. Modelo de inovação social universitária que descreva as dimensões e competências que configuram o mesmo, além dos possíveis indicadores para sua avaliação.

5. Estratégias comuns para avaliação, ensino e aprendizado das competências.

6. Orientações político-educativas para o estabelecimento de um sistema de créditos acadêmicos para a América Latina.

7. Estratégias comuns para a medição do volume de trabalho dos estudantes e sua vinculação com os resultados do aprendizado nos planos de estudo.

8. Quinze redes temáticas de universidades europeias e latino-americanas trabalhando de forma ativa para a reforma e modernização das diplomações e do reconhecimento.

9. Uma Rede de Responsáveis da Política Universitária (Centros Nacionais Tuning) trabalhando de forma ativa, e ainda aportando seu apoio e contexto político para as universidades.

Completados 10 anos de intenso trabalho, o Tuning América Latina construiu um espaço de diálogo e continua avançando em busca dos seus objetivos, frutos do empenho e do comprometimento de todos os envolvidos. Em 2014 foram lançados vários livros (documentos) ${ }^{6}$ que trazem os registros dessas conquistas. No próximo capítulo vamos conhecer melhor a metodologia a que se refere o Projeto Tuning.

$\overline{6}$ Todos os livros e documentos estão disponíveis na página oficial do projeto. 


\section{Metodologia Tuning}

\subsection{Metodologia Tuning}

No capítulo 2 buscou-se explicar o funcionamento, de modo geral, do Projeto Tuning, o ciclo de desenvolvimento dinâmico da qualidade Tuning, no que consiste o sistema ECTS - Sistema Europeu de Transferência e Acumulo de Créditos, o CLAR Crédito Latinoamericano de Referêcia e toda a estrutura trabalhada com os resultados do aprendizado e competências em unidades ou módulos de um curso. Compreendida cada uma dessas peças ficará mais simples compreender o Projeto Tuning América Latina como um todo.

Essa metodologia foi pensada para facilitar a compreensão dos planos de estudo e sua mútua comparação. Com base no Anexo I do Relatório Final - Projeto Tuning América Latina (2004-2007) são cinco as linhas de abordagem que se distinguiram para organizar a discussão nas áreas de conhecimento:

1. Competências gerais (acadêmicas de caráter geral);

2. Competências específicas de cada área;

3. A função de ECTS (Sistema Europeu de Transferência e Acumulação de créditos) como um sistema de acumulação;

4. Enfoques da aprendizagem, didáticos e de avaliação, e

5. A função da promoção da qualidade no processo educacional (insistindo em sistemas baseados em uma cultura de qualidade institucional interna).

As três primeiras linhas foram foco na primeira fase do Projeto Tuning ${ }^{1}$ enquanto que a quarta e quinta ocuparam destaque na segunda fase do projeto (2003-2004) visto que na primeira fase tiveram pouca atenção. Essas linhas de abordagem foram desenvolvidas antecipadamente entre grupos de especialistas das nove áreas do conhecimento.

Juntas, as cinco linhas de abordagem permitem que as universidades possam harmonizar seus planos de estudos sem perder sua autonomia e simultaneamente tendo a sua capacidade de inovação estimulada.

1 Quando se fizer menção somente à Tuning será em referência a metodologia Tuning em geral e quando fizer referência ao projeto da América Latina se explicitará Projeto Tuning América Latina. 


\subsection{O Modelo Tuning}

O projeto Tuning desenvolveu um modelo global de planos de estudos a serem oferecidos em uma instituição ou, de forma conjunta por duas ou mais instituições. O processo de estruturação de um programa de estudos local, integrado ou um título conjunto (internacional) pressupõe as seguintes etapas principais:

1. Cumprimento das condições básicas aplicadas a todos os programas de estudos: Identificar a necessidade social do programa, a nível regional, nacional, ou europeu. Esse levantamento deve ser feito mediatamente consulta às partes interessadas, empresários, profissionais e organismos profissionais. Verificar se o programa possui interesse suficiente do ponto de vista acadêmico. Identificar pontos de referência comuns. Analisar a existência de disponibilidade dos recursos necessários para a implantação do programa dentro da instituição ou instituições (associadas) envolvidas, ou, se for o caso, fora delas.

2. Cumprimento das condições básicas aplicadas a programas internacionais de titulação oferecidos por mais de uma instituição: Verificar se as instituições envolvidas expressam seu compromisso suficientemente, analisando de que modo isso é feito, através de um convênio (oficial) ou uma aliança estratégica. Certificar as garantias suficientes de que o programa será reconhecido, com efeitos legais, nos diferentes países. Possuir um acordo sobre a extensão do programa a ser desenhado em termos de créditos ECTS baseados no trabalho do aluno.

3. Definição do perfil exigido para obtenção do título.

4. Descrição dos objetivos do programa e os resultados de aprendizagem (em termos de conhecimentos, compreensão, habilidades e capacidades) que deverão ser cumpridos.

5. Identificação das competências gerais e específicas de cada área que devem ser alcançadas no programa.

6. Tradução do plano de estudos: conteúdo (temas a serem abordados) e estrutura (módulos e créditos).

7. Tradução das unidades e atividades educacionais para se obter os resultados de aprendizagem que foram definidos.

8. Definição dos enfoques didáticos e de aprendizagem (tipos de métodos, técnicas e formatos) e dos métodos de avaliação (caso necessário, desenvolvendo material didático).

9. Desenvolvimento de um sistema de avaliação concebido para se incrementar, constantemente, sua qualidade.

Segundo documentos, este modelo parte da hipótese de que os programas podem, e devem ser aperfeiçoados, não só através de uma retroalimentação, bem como uma alimentação prospectiva, considerando os desenvolvimentos da sociedade e os campos 
acadêmicos envolvidos.

\subsection{ECTS (European Credit and Accumulation System) - Sistema Europeu de Transferência e Acúmulo de Créditos}

O ECTS foi criado a partir de um projeto piloto administrado pela Comissão Europeia entre 1988-1995, pensado inicialmente para suscitar a mobilidade estudantil na Europa e facilitar a transferência de créditos completados no estrangeiro.

O Projeto Tuning inovou ao vincular os resultados da aprendizagem, as competências e os créditos baseado no trabalho do aluno. Para tanto, foi necessário, dentro do Tuning, redefinir o conceito de ECTS.

Desta forma, está definido no glossário de termos do Relatório Final - 2004-2007

ECTS (Sistema Europeu de Transferência e Acumulo de Créditos) é um sistema centrado no aluno, baseado no trabalho exigido do aluno para alcançar os objetivos de um programa de estudos. Os objetivos devem ser especificados em termos de resultados da aprendizagem e competências a serem adquiridas. [...] Trata-se de um sistema destinado a incrementar a transferência dos sistemas educacionais e a facilitar a mobilidade dos alunos pela Europa, mediante a transferência e acumulação de créditos. A transferência dos créditos está garantida mediante acordos explícitos entre a instituição de origem, a instituição de destino e aluno. (BENEITONE et al., 2007)

Conforme este conceito os créditos têm um valor absoluto, e não mais relativo, e estão vinculados a resultados da aprendizagem.

No ECTS os créditos são conferidos de acordo com a quantidade de trabalho exigida por cada um dos componentes educativos ${ }^{2}$ para atingir os objetivos específicos, ou os resultados de aprendizagem, em relação ao montante total para concluir com sucesso um ano de estudos. Entende-se por tempo de trabalho do estudante, todo o tempo exigido para desenvolver as atividades de aprendizagem³ planejadas. (BENEITONE et al., 2007)(CLAR, 2013)

\subsubsection{O ECTS no contexto Latino americano}

Nos meses que antecederam a $2^{\text {a }}$ Reunião Geral de 2011, foi feito pelos CNT um levantamento que concluiu que, na maior parte dos países latino-americanos não existe um sistema difuso e uniforme de créditos acadêmico e onde existem são diversificados, além de pouco valorizar as práticas pré-profissionais e atividades independentes como geradoras de

2 Componentes educativos: disciplinas, módulos, cursos, práticas, monografias, entre outras.

3 Atividades de aprendizagem: aulas, seminário, oficinas, estudo independente e privado, práticas, preparação de projetos, exames, saídas a campo e excursões, práticas profissionais. 
créditos acadêmicos, além disso, não existe um sistema de créditos acadêmicos partilhados por todos. Na verdade existem algumas experiências diversificadas e de difícil homologação espalhadas por alguns países como Uruguai, Chile, Colômbia, Brasil, entre outros.

Cada vez mais acentuada a mobilidade estudantil entre países da Europa, América do Norte, África e os latino-americanos, as universidades veem a necessidade de se pensar em estabelece um sistema de créditos latino-americanos que facilite o reconhecimento dos estudos realizados. Hoje esses reconhecimentos são feitos disciplina por disciplina, semestre por semestre. (CLAR, 2013)

A proposta de um sistema de créditos acadêmicos para a América Latina é na verdade o sexto objetivo ${ }^{4}$ do Projeto Tuning América Latina. Um sistema como esse é fundado na interdependência de alguns elementos (CLAR, 2013):

1 - O perfil do título de graduação, que indica as competências que devem ser desenvolvidas.

2 - Os resultados da aprendizagem especificados para cada disciplina/módulo/semestre/curso.

3 - As atividades educativas que melhor garantem que serão alcançados os resultados da aprendizagem.

4 - O tempo (medido em horas), baseado no trabalho do estudante, que em média será requerido para realizar as atividades educativas que sejam necessárias para alcançar os resultados de aprendizagem.

No projeto Tuning o tempo necessário para alcançar as mesmas competências e resultados de aprendizagem por parte dos estudantes pode variar em função do contexto, ou seja, métodos de ensino, a avaliação, desenho do projeto pedagógico do curso, organização do ensino, a capacidade e a postura do estudante, sem contar a diversidade de tradições, portanto, tudo isso deve ser levado em consideração ao medir os resultados de aprendizagem.

Em decorrência do contexto da América Latina, criou-se o Crédito Latino-americano de Referência - CLAR, sua origem foi na segunda Reunião Geral do Projeto Tuning América Latina em 2011 na Guatemala quando os países participantes concordaram com a necessidade de um sistema de créditos de referência para as universidades da região.

O Crédito Latino-americano de Referência (CLAR) é concebido como uma unidade de valor que estima o volume de trabalho, medido em horas, requerido por um estudante para lograr resultados de aprendizagem e ser aprovado em uma disciplina ou período letivo. (CLAR, 2013)

Encarado como um sistema de reconhecimento e desenvolvimento da qualidade do trabalho acadêmico, o sistema tem três principais objetivos:

- Favorecer o desenvolvimento de uma reforma curricular.

$\overline{4}$ Os objetivos estão descritos no capitulo 1. 
- Estimular o crédito como fator de promoção da qualidade nos programas de formação.

- Promover a mobilidade estudantil entre as universidades latino-americanas a partir de um sistema compartilhado de reconhecimento do trabalho acadêmico do estudante.

O objetivo do CLAR é a melhoria sucessiva da qualidade dos programas nos sistemas nacionais, da estimulação a inovação curricular, de uma maior cooperação acadêmica entre as instituições de educação superior na América Latina, de facilitar a mobilidade estudantil dentro dos sistemas nacionais de educação superior latino-americano, além de suscitar a reflexão sobre o tempo que um aluno necessita para desenvolver as tarefas e alcançar as competências de certa atividade curricular.

Além disso, o CLAR como um sistema de créditos transferíveis visa por meio de um plano de convenção comum facilitar a transferência e o deslocamento estudantil e acadêmico entre as instituições de educação superior latino americana, além de buscar facilitar o recíproco reconhecimento de atividades e cursos acadêmicos realizados pelos estudantes envolvidos nos processos de mobilidade estudantil.

O uso de um normalizador foi mais um dos acordos alcançados na segunda Reunião Geral do Tuning América Latina em novembro de 2011. Definido como 60 créditos, isso equivale a uma carga de trabalho de um ano de estudo em tempo completo. Assim se um ano equivale a 60 créditos, um semestre equivale a 30 créditos e para um programa de estudos de quatro anos tem-se 240 créditos, isso de acordo com cursos e programas nos vários países.

Na América Latina a duração de um ano acadêmico varia não só de um país para o outro, como também entre as instituições de um mesmo país. Em levantamentos feitos pelos Centros Nacionais Tuning dos diversos países participantes do projeto, observou-se que as semanas de trabalho acadêmico durante um ano girava em torno de 32 a 40 semanas, na maioria das instituições de Educação Superior da América Latina. Diante disso, para o crédito latino-americano CLAR, será usado como referência o ponto médio do intervalo de variação, ou seja, 36 semanas. Para calcular o valor de um crédito são necessários três elementos:

- Número de semanas anuais definido por cada instituição para o trabalho acadêmico, no geral 36 semanas;

- Número de horas semanais que o aluno dispõe para estudo, definido entre 40 e 55 horas;

- Número total de créditos em um ano acadêmico para um programa de estudos que conduz a um grau acadêmico ou a um título profissional, definido em 60 créditos.

Vale ressaltar que o número de horas semanais de trabalho do estudante não deve 
ultrapassar às 55 horas, uma vez que é real a necessidade que ele tem de descanso e dedicação a outras atividades e interações sociais. O número de créditos deve ser distribuído entre todos os componentes curriculares previstos no Projeto Pedagógico do Curso e não somente aquelas que possuam interação direta professor/estudante, esse é um dos diferenciais do CLAR.

O cálculo de um crédito CLAR é realizado utilizando a Equação 2.1

$$
\frac{(\text { semana do ano }) X(\text { horas de trabalho semanal })}{\text { numero total de créditos em } 1 \text { ano acadêmico }}=\text { valor de um crédito } C L A R
$$

Ou seja, para uma carga de trabalho do estudante de 40 horas semanais

$$
\frac{36.40}{60}=\frac{1440}{60}=24 h / \text { crédito }
$$

Para uma carga de trabalho do estudante de 55 horas semanais

$$
\frac{36.55}{60}=\frac{1980}{60}=33 h / \text { crédito }
$$

Portanto um crédito CLAR varia entre 24 e 33 horas cronológicas de trabalho do estudante.

O volume de tempo de trabalho concedido a um crédito CLAR é determinado a partir do tempo total que um estudante dedica anualmente à aprendizagem. Caso o ano letivo seja diferente de 36 semanas, o número de horas de trabalho semanal do estudante pode até variar, no entanto deve-se respeitar a faixa limite de horas de trabalho no ano, estabelecida entre 1440 e 1980. Por exemplo, se em uma instituição o ano acadêmico é planejado em 33 semanas, com 44 horas semanais de trabalho do estudante, o número total de horas de trabalho será igual a 1452 horas ao ano que divido por 60, dará um crédito no valor de 24,2 horas cronológicas. Essas variações podem ocorrer desde que seja respeitada a faixa estabelecida evitando uma variabilidade excessiva do CLAR. (CLAR, 2013)

\subsection{Resultados da aprendizagem e competências}

O projeto Tuning institui uma distinção entre resultados de aprendizagem e competências. A intenção é diferenciar os papeis do corpo docente e dos alunos. Os resultados da aprendizagem são formulados pelos professores sendo recomendado que aja o envolvimento de representantes dos alunos nesse processo, ou seja, são formulações do que o aluno deve conhecer ou ser capaz de demonstrar, com a finalização do processo de aprendizagem. Os 
resultados da aprendizagem especificam os resultados mínimos para a concessão de um crédito.

Já as competências são desenvolvidas e adquiridas pelo aluno ao longo do processo de aprendizagem. As competências são desenvolvidas em diferentes etapas, elas representam uma combinação dinâmica de conhecimento, compreensão, habilidades e capacidades.

O Relatório Final - Projeto Tuning América Latina 2004-2007 (ver Beneitone et al. (2007)) trás uma definição ampla do que seja competência.

Competências: Conjunto de conhecimentos, habilidades e destrezas, tanto específicas como transversais, que um titulado deve reunir para satisfazer plenamente as exigências dos contextos sociais. Fomentar as competências é o objetivo dos programas educacionais. As competências são capacidades que a pessoa desenvolve, gradualmente, ao longo de todo o processo educacional e são avaliadas em diferentes etapas. Podem estar divididas em competências relacionadas com a formação profissional geral (competências gerais) e com uma determinada área de conhecimento (específicas de um campo de estudo).

A ideia do projeto é fazer das competências pontos de referência para a estruturação e a avaliação dos planos de estudo, tais pontos asseguram a flexibilidade e capacidade de atuar com independência na elaboração dos planos de estudos, além de oferecer uma linguagem compartilhada.

Se comparados a programas de estudos nos moldes tradicionais, os programas que utilizam os resultados da aprendizagem são muito mais flexíveis, deixando claro que, mesmo utilizando caminhos diferentes, esses podem conduzir a resultados comparáveis e de simples reconhecimento como parte de outro programa ou como base fundamental para o acesso a um programa de outro ciclo.

Para se introduzir um sistema baseado em ciclos é necessário que aja uma revisão em todos os programas de estudos existentes que não estejam fundamentados na concepção de ciclos. O ensino superior é tradicionalmente dividido em dois ciclos ou níveis: graduação e pós-graduação. Segundo consta no glossário da Rede Ibero- Americana para a acreditação do Ensino Superior (RIACES) ${ }^{5}$ (ACREDITACIÓN, 2004), o Espaço Europeu de Ensino Superior adota uma estrutura de ensino superior dividida em três ciclos: grau/bacharelado, mestrado e especialização e o doutorado. Em alguns países, são contemplados três ciclos: graduação, grau/bacharelado e pós-graduação. A denominação dos títulos ou certificados conferidos quando o aluno completa cada um dos ciclos é variável, dependendo do sistema de ensino superior, usando-se, às vezes, denominação igual para certificados correspondentes a um ciclo distinto.

O emprego de resultados de aprendizagem e competências se faz necessário para que os programas de estudos ou módulos de cursos estejam centrados no estudante. Dessa forma

\footnotetext{
5 Mais informações buscar em Glosario Internacional Riaces de Evaluacion de La calidad y acreditación.
} 
os conteúdos do programa de estudo ficam determinados pelos conhecimentos e habilidades mais significativas que o estudante deve adquirir durante o processo de aprendizagem.

Um programa estruturado dessa maneira tem como enfoque principal o perfil de qualificação ou o título. Esse perfil é deliberado tanto pelo corpo docente como pelos grupos de interesse externo, todos decidem que competências (gerais e específicas) devem ser dadas ênfase e até que ponto isso deve ser feito. Único e baseado no parecer e na decisão do corpo docente, o perfil programático deve levar em consideração os traços específicos que sejam considerados cruciais para a área do conhecimento em questão. Em um sistema de ciclos, cada um deles deveria contar com seu próprio grupo de resultados de aprendizagem, formulados em termos de competências. (BENEITONE et al., 2007)

Durante as etapas e as várias unidades ou módulos que um programa possui, as competências vão sendo modeladas e desenvolvidas gradativamente, mas deve estar claro em que unidade tal competência específica será formada. Mesmo que ajam competências que possam ser modeladas implicitamente em um programa, somente aquelas passíveis a avaliação devem ser vinculadas explicitamente ao programa.

No programa de estudo em que o aluno é o centro e orientado para outputs ${ }^{6}$, todas as unidades, seja ela optativa ou do núcleo principal, estão ligadas uma com as outras direta ou indiretamente.

Além da opção tradicional de cursar um programa semestralmente, o modelo sugere outras opções como, cursar unidades no sentido vertical, desde que sejam cumpridos os pré-requisitos de tal unidade.

\subsection{Competências}

Em 1998 a Conferência Mundial sobre o Ensino Superior promovida pela Unesco em Paris debateu ações para a mudança e desenvolvimento do ensino superior em âmbito internacional. Várias foram as propostas e, além da melhoria e conservação da qualidade do ensino superior, propôs-se a formação baseada no desenvolvimento de competências técnicas apropriadas para colaborar ao desenvolvimento cultural, social e econômico.

Como visto anteriormente, as competências compõem a primeira e segunda linha de trabalho da metodologia Tuning e a primeira linha de trabalho do Tuning América Latina a qual propõe analisar tanto as competências gerais quanto as específicas.

Iniciado em 2004, uma das primeiras tarefas do Tuning América Latina estava em definir as competências gerais e, foi tomado como base as 30 competências gerais identificadas na Europa ${ }^{7}$, o CNT de cada país elaborou uma lista com as suas sugestões

6 Outputs: entre outros significados, em português quer dizer ação de transferir para o meio externo.

7 Lista de competências gerais acordadas pela Europa na web do projeto Tuning Europa: $<$ http: //tuning.unideusto.org/tuningeu/> 
chegando-se a uma lista comum de 85 competências gerais e, após reflexões e debates durante a primeira Reunião Geral do Tuning América Latina em 2005 chegou-se ao consenso de 27 competências gerais, que estão listadas na Tabela 2.

Tabela 2 - Competências Gerais.

\begin{tabular}{|c|c|}
\hline Siglas & Competências \\
\hline CG01 & Capacidade de abstração, análise e síntese. \\
\hline CG02 & Capacidade de aplicar os conhecimentos na prática. \\
\hline CG03 & Capacidade para organizar e planejar o tempo. \\
\hline CG04 & Conhecimentos sobre a área de estudo e a profissão. \\
\hline CG05 & Responsabilidade social e compromisso cidadão. \\
\hline CG06 & Capacidade de comunicação oral e escrita. \\
\hline CG07 & Capacidade de comunicação em um segundo idioma. \\
\hline CG08 & Habilidades no uso das tecnologias da informação e da comunicação. \\
\hline CG09 & Capacidade de pesquisa. \\
\hline CG10 & Capacidade de aprender e atualizar se permanentemente. \\
\hline CG11 & Habilidades para buscar, processar e analisar informações com fontes diversas. \\
\hline CG12 & Capacidade crítica e autocrítica. \\
\hline CG13 & Capacidade para atuar em novas situações. \\
\hline CG14 & Capacidade criativa. \\
\hline CG15 & Capacidade para identificar, apresentar e resolver problemas. \\
\hline CG16 & Capacidade para tomar decisões. \\
\hline CG17 & Capacidade de trabalho em equipe. \\
\hline CG18 & Habilidades interpessoais. \\
\hline CG19 & Capacidade de motivar e liderar metas comuns. \\
\hline CG20 & Compromisso com a preservação do meio ambiente. \\
\hline CG21 & Compromisso com seu meio sociocultural. \\
\hline CG22 & Valorizar e respeitar a diversidade e multiculturalidade. \\
\hline $\mathrm{CG} 23$ & Habilidade para trabalhar em contextos internacionais. \\
\hline CG24 & Habilidade para trabalhar de forma autônoma. \\
\hline CG25 & Capacidade para formular e gerenciar projetos. \\
\hline CG26 & Compromisso ético. \\
\hline CG27 & Compromisso com a qualidade. \\
\hline
\end{tabular}

Fonte: Próprio autor com base em Beneitone et al. (2007), 2015.

A formação por competências sugere acabar com os obstáculos entre o conhecimento acadêmico e científico e o conhecimento adquirido no dia a dia. Esse modelo pedagógico resulta a formação integral englobando os conhecimentos, habilidades, destrezas, comportamentos e princípios. São atribuídas inúmeras vantagens a um ensino baseado no conceito 
de competências, entre outras se destaca o desenvolvimento de um novo paradigma de educação, primordialmente centrado no aluno e na necessidade de direcionar-se para gestão do conhecimento. As competências são capazes de selecionar os conhecimentos apropriados para fins estabelecidos.

Quanto as competências específicas referem-se às capacidades esperadas pelos estudantes por áreas específicas, como por exemplo, matemática, história, administração de empresas dentre outras.

O desenvolvimento curricular baseado em competências estabelece um modelo repleto de benefícios para todas as partes envolvidas: instituições, docentes, alunos, empregadores e a sociedade. No entanto não é algo simples porque gera resistência à mudança pelo conflito de interesses próprios e pelos múltiplos enfoques de disciplinas diferentes. Mas vale ressaltar que as competências gerais ou habilidades transferíveis estão se tornando cada vez mais importantes no momento de preparar bem os alunos para exercerem seu futuro papel na sociedade. 


\section{Proposta do Projeto Tuning América La- tina na área da Matemática}

\subsection{Introdução}

A matemática foi uma das quatro áreas iniciais do Projeto e este capítulo será destinado às reflexões e perspectivas sobre essa importante área do ponto de vista do Projeto Tuning América Latina. As informações aqui contidas são resultado do trabalho de equipe dos participantes da área de matemática para o Projeto Tuning América Latina: Inovação Educativa e Social (2011 - 2013). No Relatório Final de 2007 consta um mapa da Área de Matemática, que centrava a formação dos matemáticos com perspectiva profissional em vários setores da sociedade e não apenas voltado para as unidades de ensino. Mesmo passados seis anos algumas considerações lá apresentadas permanecem inalteradas. Assim é necessário entender primeiramente em que contexto as atividades da área foram realizadas na esfera do Projeto Tuning América Latina e no qual atualmente é formado o profissional de matemática.

Com exceção do Brasil e da Colômbia, os demais países da América Latina utilizam o termo Licenciatura para designar cursos associados à matemática. No Brasil há duas opções de qualificação para os matemáticos: Licenciatura (habilitação para atuar como professor em instituições de ensino básico) e Bacharelado (habilitação para atuar como pesquisador). Já na Colômbia o termo licenciatura é utilizado para os cursos que formam exclusivamente docentes e para os outros programas que formam matemáticos utiliza-se a denominação de cursos.

É interessante observar a variação na nomenclatura dos cursos destinados à formação de matemáticos. Veja: Licenciatura em Matemática, Licenciatura e Matemática Aplicada, Bacharelado em Matemática e Bacharelado em Matemática Aplicada, Engenharia em Matemática, Licenciatura em Ciências Matemáticas, Licenciatura em Ciência Física e Matemática, Licenciatura em Estatística, Licenciatura em Ciências Estatísticas, Licenciatura em Ciências Atuariais e Atuária. E mesmo os cursos destinados exclusivamente à formação docente recebem nomes diversos, como por exemplo, Licenciatura em Docência Matemática, Licenciatura em Ensino de Matemática, Licenciatura em Matemática, Professorado em Ensino Médio e Superior de Matemática, entre outros.

O estudo da matemática já está presente na América Latina há vários séculos, mas somente a partir do século XX que foram iniciados os primeiros programas nessa área. Até então os cursos que existiam estavam vinculado às escolas de engenharia ou visavam à formação de professores de matemática de ensino fundamental e médio. Com o passar 
dos anos algumas instituições foram criadas para fomentar tanto o desenvolvimento da matemática pura quanto da aplicada.

Não existe um programa de estudo unificado nos países da região. O tempo de formação dura entre quatro e seis anos e o trabalho de conclusão de curso, dissertação ou tese para obtensão do grau universitário também varia e os requisitos são os mais diversos. O único país que possui um programa de estudos unificados é Cuba.

Existem hoje inúmeras políticas educacionais que estimula a internacionalização e isso faz com que programas e projetos de interesse comum sejam impulsionados, incluindo a mobilidade de acadêmicos e estudantes. As universidades, os institutos de pesquisa e as diversas sociedades científicas da maioria dos países participantes do Projeto Tuning América Latina são solicitas ao trabalho de intercâmbio e propagação do conhecimento matemático, para tanto são feitas reuniões e conferências de âmbito nacional e internacional abrangendo as inúmeras subáreas da matemática.

As disciplinas de matemática estão presentes na formação de profissionais nas mais diversas áreas. Em algumas universidades existe um sistema de divisão em departamentos, no entanto, isso não constitui uma característica geral entre os países latino-americanos, apenas presente em Brasil, Cuba e México.

A qualidade da aprendizagem da matemática em todos os níveis ainda é uma preocupação para a América Latina, pouco desenvolvida, a pesquisa na área da matemática é fraca, o crescimento e a instituição da pós-graduação em matemática ainda trás importantes desafios e, mesmo nos países onde existe, o programa não possui uma abrangência nacional. Contudo os programas de pós-graduação vêm crescendo e buscando se fortalecer. Assim de maneira progressiva os perfis relacionados à matemática aplicada são inseridos nos currículos dos cursos, isso porque os professores e pesquisadores das diversas instituições têm buscado experiências de trabalho conjunto com outros organismos, bem como atividades e políticas de internacionalização, fortalecendo o crescimento e a diversidade dos projetos na área da matemática.

As universidades na sua grande maioria são autônomas e institui de maneira independente o currículo dos cursos de graduação, mestrados e doutorados. Mesmo autônoma as universidades podem ter seus programas sujeitos à avaliação e aprovação dos ministérios responsáveis pelo ensino superior. No entanto, as instituições admitem que seja cada vez mais essencial adequar os currículos dos cursos para alcançar as competências almejadas para um profissional da área. (PANIAGUA et al., 2014) 


\subsection{Competências Específicas na Matemática}

No intuito de desenvolver as competências necessárias para uma formação completa, boa parte dos países da região sugeriram mudanças nos planos e programas dos cursos relativos à formação profissional em matemática. A ênfase dada às competências que as instituições devem fazer com que os estudantes desenvolvam é devida as capacidades esperadas dos profissionais de matemática. Uma convergência curricular focada nas competências contribuirá para um melhor desenvolvimento das atividades do futuro profissional na área da matemática.

Na $2^{\text {a }}$ Reunião Geral do Projeto Tuning América Latina, em agosto de 2005 no Brasil foi elaborada uma lista com 23 competências específicas da área, para chegar a esse número foram analisadas propostas de 15 universidades latino americanas da área de matemática. Essa lista final trás as competências consideradas importantes, e necessárias que todos os graduados em nível superior venham a desenvolver. A Tabela 3 relaciona as 23 competências específicas da área da matemática.

Segundo o Relatório final (2004-2007), foi realizada uma pesquisa sobre as competências da área da matemática ${ }^{1}$ com 1398 entrevistados, entre acadêmicos, graduados e alunos. Para os três grupos todas as 23 competências foram consideradas extremamente importantes, mas a competência número 1 obteve valorização superior à média (BENEITONE et al., 2007)

O interessante é observar que o desenvolvimento de uma determinada competência não se faz isoladamente. Por exemplo, essa competência "Domínio dos conceitos básicos da matemática de nível superior" está vinculada com outras competências tais como CE02, CE03, CE06, CE09, além de ser desenvolvida durante todo o programa de estudo através da participação ativa do aluno em todas as etapas do processo educacional.

$1 \quad$ Mais detalhes dessa pesquisa pode ser encontrado no capitulo 4 do Relatório final - Projeto Tuning América Latina 2004-2007 
Tabela 3 - Competências específicas da área da Matemática.

\begin{tabular}{|c|c|}
\hline Siglas & Competências \\
\hline CE01 & Domínio dos conceitos básicos de matemática de nível superior. \\
\hline CE02 & $\begin{array}{l}\text { Capacidade para construir e desenvolver argumentações lógicas, com uma identificação } \\
\text { clara de hipóteses e conclusões. }\end{array}$ \\
\hline CE03 & Capacidade para expressar-se corretamente, utilizando a linguagem matemática. \\
\hline CE04 & $\begin{array}{l}\text { Capacidade de abstração, inclusive, o desenvolvimento lógico de teorias matemáticas } \\
\text { e as relações entre elas. }\end{array}$ \\
\hline CE05 & $\begin{array}{l}\text { Capacidade para formular problemas em linguagem matemática, de maneira a facilitar } \\
\text { sua análise e solução. }\end{array}$ \\
\hline CE06 & Conhecimento da evolução histórica dos conceitos fundamentais da matemática. \\
\hline CE07 & Capacidade para iniciar pesquisas matemáticas, sob a orientação de especialistas. \\
\hline CE08 & $\begin{array}{l}\text { Capacidade para formular problemas de otimização, tomar decisões e interpretar as } \\
\text { soluções nos contextos originais desses problemas. }\end{array}$ \\
\hline CE09 & $\begin{array}{l}\text { Capacidade para contribuir na construção de modelos matemáticos, a partir de } \\
\text { situações reais. }\end{array}$ \\
\hline CE10 & $\begin{array}{l}\text { Capacidade para utilizar as ferramentas computacionais de cálculo numérico e sim- } \\
\text { bólico para propor e resolver problemas. }\end{array}$ \\
\hline CE11 & Destreza em cálculos quantitativos. \\
\hline CE12 & ade para compreender problemas e abstrair deles o que for essencial. \\
\hline CE13 & Capacidade para extrair informação qualitativa de dados quantitativos. \\
\hline CE14 & Disposição para enfrentar novos problemas em áreas distintas. \\
\hline CE15 & Capacidade para trabalhar com dados experimentais e contribuir para sua análise. \\
\hline CE16 & $\begin{array}{l}\text { Capacidade para comunicar-se com outros profissionais não matemáticos e prestar-lhes } \\
\text { assessoria na aplicação das matemáticas em suas respectivas áreas de trabalho. }\end{array}$ \\
\hline CE17 & Capacidade para trabalhar em equipes interdisciplinares. \\
\hline CE18 & $\begin{array}{l}\text { Capacidade para apresentar, ao público alvo, raciocínios matemáticos e suas con- } \\
\text { clusões, com clareza e precisão, e de forma apropriada, tanto oralmente como por } \\
\text { escrito. }\end{array}$ \\
\hline CE19 & Conhecimento básico do processo de ensino-aprendizagem das matemáticas. \\
\hline CE20 & $\begin{array}{l}\text { Domínio da matemática elementar, ou seja, a que deve ser incluída no ensino pré- } \\
\text { universitário. }\end{array}$ \\
\hline CE21 & $\begin{array}{l}\text { Capacidade de participar da elaboração dos programas de formação matemática nos } \\
\text { níveis pré-universitários. }\end{array}$ \\
\hline $\mathrm{CE} 22$ & Capacidade de detectar inconsistências. \\
\hline CE23 & $\begin{array}{l}\text { Conhecimentos de inglês para ler, escrever e expor documentos no referido idioma } \\
\text { bem como, comunicar-se com outros especialistas. }\end{array}$ \\
\hline
\end{tabular}

Fonte: Próprio autor com base em Beneitone et al. (2007), 2015. 


\subsection{Meta Perfil do graduado em Matemática}

O meta-prefil é um dos sete objetivos² do Projeto Tuning América 2011 a 2013. Os trabalhos para determinação do meta-perfil do graduado em matemática iniciou-se durante a primeira fase do projeto pelos integrantes da área de matemática.

\footnotetext{
Os meta-perfis são as representações das estruturas as áreas e as combinações de competências (genéricas e específicas) que dão identidade à área disciplinar. Os meta-perfis são construções mentais que categorizam as competências em componentes reconhecíveis e que ilustram suas interconexões. (PANIAGUA et al., 2014)
}

No processo de construção do meta-perfil do graduado de matemática utilizou-se uma dinâmica de selecionar e separar as competências genéricas e específicas, associando-as e agrupando-as em quatro dimensões ou componentes, que cada estudante deve adquirir durante o decorrer do curso de graduação. As quatro dimensões: atitudinal, disciplinar, comunicacional e relacional, foram definidas a partir da análise das cinquenta competências (27 genéricas e 23 específicas) e após esse agrupamento determinou-se uma lista de 15 competências genéricas e 14 competências específicas consideradas privilegiadas. A primeira dimensão diz respeito à atitude que o futuro matemático deve ter no exercício profissional, a segunda está relacionada ao saber fazer da disciplina, seguida das duas últimas dimensões que estão relacionadas à comunicação e às habilidades interpessoais do futuro profissional de matemática. (PANIAGUA et al., 2014)

Conforme Beneitone, González e Wagenaar (2014), as competências genéricas e específicas que facultaram origem ao meta-perfil em cada uma das dimensões, estão relacionadas na Tabela 4.

Vale ressaltar que todas as competências são igualmente importantes, mas considerase que as que não foram aqui destacadas podem ser adquiridas como consequência do desenvolvimento de outras e a sua evolução está intimamente relacionada com os antecedentes de formação e o interesse do futuro matemático.

Após essa dinâmica de seleção, análise e agrupamento das competências genéricas e das competências específicas em quatro dimensões, cada uma com um propósito específico, mas todas convergindo para um único propósito: a construção do meta-perfil.

O meta-perfil da área de matemática foi enfim traçado da seguinte forma:

- O graduado em Matemática é um profissional com ética e sensibilidade humana, responsabilidade social e compromisso com a cidadania, disposto a aprender, atualizar-se constantemente e enfrentar novos problemas em diferentes áreas.

2 Os objetivos da segunda fase estão descritos no capítulo 1. 
Tabela 4 - As competências genéricas e específicas que facultaram origem ao meta-perfil em cada uma das dimensões.

\begin{abstract}
Dimensão Atitudinal:
Refere-se às competências necessárias que sejam desenvolvidas por um matemático com sensibilidade humana e compromisso com a sociedade deve desenvolver.
\end{abstract}

\section{Dimensão Disciplinar} Refere-se às competências que um matemático com uma sólida formação deve desenvolver no que diz respeito a conhecimentos, habilidades e destrezas próprias da área e suas aplicações.
CG5-Responsabilidade social e compromisso com a cidadania. CG10-Capacidade de aprender e de se atualizar constantemente. CG26-Compromisso ético. CE14-Disposição para enfrentar novos problemas em áreas distintas

CG01-Capacidade de abstração, análise e síntese. CG02-Capacidade de aplicar os conhecimentos à prática. CG04-Conhecimentos sobre a área de estudo e a profissão. CG08-Habilidade no uso das tecnologias da informação e da comunicação. CG15-Capacidade de identificar, definir e resolver problemas. CG25-Capacidade de formular e administrar projetos. CE01-Domínio dos conceitos básicos de matemática de nível superior. CE02-Capacidade para construir e desenvolver argumentações lógicas, com uma identificação clara de hipóteses e conclusões. CE04-Capacidade de abstração, inclusive, o desenvolvimento lógico de teorias matemáticas e as relações entre elas. CE05-Capacidade para formular problemas em linguagem matemática, de maneira a facilitar sua análise e solução. CE07-Capacidade para iniciar pesquisas matemáticas, sob a orientação de especialistas. CE09-Capacidade para contribuir na construção de modelos matemáticos, a partir de situações reais. CE15-Capacidade para trabalhar com dados experimentais e contribuir para sua análise. CE19-Conhecimento básico do processo de ensino-aprendizagem das matemáticas.

CG06 - Capacidade de comunicação oral e escrita. CG07 - Capacidade de comunicação em um segundo idioma. CE03 - Capacidade para expressarse corretamente, utilizando a linguagem matemática. CE16 - Capacidade para comunicar-se com outros profissionais não matemáticos e prestarlhes assessoria na aplicação das matemáticas em suas respectivas áreas de trabalho. CE18 - Capacidade para apresentar, ao público alvo, raciocínios matemáticos e suas conclusões, com clareza e precisão, e de forma apropriada, tanto oralmente como por escrito. CE23 - Conhecimentos de inglês para ler, escrever e expor documentos no referido idioma bem como, comunicar-se com outros especialistas.

Dimensão Relacional: Refere-se às competências necessárias para que o matemático seja capaz de interagir com outras pessoas em diferentes contextos.
CG13-Capacidade de atuar em novas situações. CG17-Capacidade de trabalhar em equipe. CG18-Habilidades interpessoais. CG23-Habilidades para trabalhar em contextos internacionais. CE17-Capacidade de trabalhar em equipes interdisciplinares.

Fonte: Paniagua et al. (2014). 
- Possui sólida formação no que diz respeito a conhecimentos, habilidades e destrezas próprias de sua área de estudo e de sua profissão, domina os conceitos básicos da matemática superior e elabora e devolve argumentações lógicas com uma identificação clara de hipóteses e conclusões.

- Caracteriza-se por possuir uma grande capacidade de abstração e análise, incluindo o desenvolvimento lógico de teorias matemáticas e as relações entre elas e está capacitado para iniciar pesquisas matemáticas sob a orientação de especialistas.

- Aplica os conhecimentos à prática constantemente e identifica e define problemas, formulando-os em linguagem matemática a fim de facilitar sua análise e solução. Contribui para a elaboração de modelos matemáticos a partir de situações reais e para a análise de dados experimentais.

- Possui conhecimentos básicos dos processos de ensino e aprendizagem de matemática, formula e administra projetos e utiliza as tecnologias da informação e da comunicação.

- Se expressa correta e eficazmente em forma oral e escrita, domina a linguagem da matemática e apresenta os raciocínios matemáticos e suas conclusões com clareza, precisão e de forma apropriada para o público alvo.

- Lê, redige e expõe documentos em inglês para interagir com a comunidade acadêmica internacional em sua área de conhecimentos.

- Comunica-se com outros profissionais que não pertencem à área de matemática e presta assessoria para a aplicação da matemática em suas respectivas áreas de trabalho.

- Possui habilidades interpessoais para interagir com outras pessoas em diferentes contextos e para trabalhar em equipes multidisciplinares.

O meta-perfil leva em conta os problemas profissionais que os graduados em matemática terão que enfrentar ao término dos estudos e estabelece a base para o prosseguimento em estudos de pós-graduação. Dessa forma pode-se dizer que estão em estreita relação com os conteúdos disciplinares mínimos. 


\subsection{Conteúdos Curriculares da área de Matemática}

Na primeira fase do projeto foi elaborada pelos integrantes da área de matemática, uma lista dos conteúdos mínimos estimados essenciais em qualquer plano de estudos que habilite matemáticos em nível de graduação. A Tabela 5 descreve esses conteúdos.

Tabela 5 - Conteúdos mínimos de Matemática por área.

\begin{tabular}{|c|c|}
\hline Área & Conteúdos mínimos \\
\hline Álgebra Abstrata & $\begin{array}{l}\text { Conjuntos, relações e aplicações, estruturas algébricas elementares: Z, Zn, } \\
\text { Q, R, C, polinômios, grupos, subgrupos, subgrupos normais, anéis, subanéis } \\
\text { e ideais. }\end{array}$ \\
\hline Álgebra Linear & $\begin{array}{l}\text { Sistemas de equações lineares e matrizes, espaços vetoriais e aplicações } \\
\text { lineares, valores e vetores próprios. }\end{array}$ \\
\hline Análise Matemática & $\begin{array}{l}\text { Topologia de Rn, continuidade e diferenciação de funções reais e de várias } \\
\text { variáveis, integral de Riemann, sucessões e séries de funções, teorema da } \\
\text { função inversa, teorema da função implícita. }\end{array}$ \\
\hline Cálculo & $\begin{array}{l}\text { Sucessões e séries numéricas, continuidade, diferenciação e integração de } \\
\text { funções de uma e várias variáveis reais, integrais de linha e de superfície e } \\
\text { teoremas clássicos do cálculo. }\end{array}$ \\
\hline $\begin{array}{l}\text { Ciências Sociais e Hu- } \\
\text { manidades }\end{array}$ & De acordo com as especialidades presentes na instituição. \\
\hline $\begin{array}{l}\text { Didática da Matemá- } \\
\text { tica }\end{array}$ & $\begin{array}{l}\text { De acordo com as características presentes na instituição ou disciplinas em } \\
\text { estágios de modalidade. }\end{array}$ \\
\hline Equações Diferenciais & $\begin{array}{l}\text { Equações Diferenciais de primeira ordem, equações diferenciais lineares de } \\
\text { ordem superior, sistemas de equações diferenciais lineares, introdução à } \\
\text { análise qualitativa das equações e aplicações. }\end{array}$ \\
\hline $\begin{array}{l}\text { Física } \\
\text { Geometria Elementar }\end{array}$ & $\begin{array}{l}\text { Mecânica clássica e do meio contínuo. } \\
\text { Congruências de figuras, aéreas de figuras planas, semelhança de figuras, } \\
\text { circunferência, polígonos regulares. }\end{array}$ \\
\hline Geometria Analítica & Geometria elementar do plano e do espaço, sistemas de coordenadas e cones. \\
\hline $\begin{array}{l}\text { Geometria Diferencial } \\
\text { História e metodologia } \\
\text { da matemática }\end{array}$ & $\begin{array}{l}\text { Curvas e superfícies. } \\
\text { Visão panorâmica do desenvolvimento histórico da matemática e de seus } \\
\text { problemas filosóficos fundamentais }\end{array}$ \\
\hline Lógica e fundamentos & $\begin{array}{l}\text { Linguagens e sistemas formais, cálculo de enunciados e predicados, computa- } \\
\text { bilidade e decibilidade. }\end{array}$ \\
\hline $\begin{array}{l}\text { Medida e integração e } \\
\text { análise funcional }\end{array}$ & $\begin{array}{l}\text { Resultados fundamentais da teoria da medida e da integração, análise funci- } \\
\text { onal e teoria de operadores. }\end{array}$ \\
\hline Matemática Discreta & Combinatória, análise de algoritmos e teoria de grafos. \\
\hline Métodos Numéricos & $\begin{array}{l}\text { Estudo de erros, aritmética de ponto flutuante, métodos para a resolução } \\
\text { de equações e sistemas de equações lineares e não lineares, polinômios de } \\
\text { interpolação, interpolação numérica, diferenciação e integração numéricas, } \\
\text { método dos mínimos quadrados, funções de aproximação, resolução numérica } \\
\text { de equações diferenciais ordinárias. }\end{array}$ \\
\hline
\end{tabular}

Fonte: Próprio autor com base em Paniagua et al. (2014). 
Concluída a etapa da construção do meta-perfil da área de matemática para a América Latina efetuou-se então uma comparação com os planos de estudos vigentes nas universidades dos países participantes do projeto e contatou-se que na maioria deles não há um perfil elaborado explicitamente em termos de competências, apesar de conter de forma explícita ou, muita vezes implícita, boa parte das competências que estruturam o metaperfil da área de matemática do Projeto Tuning América Latina. É importante mencionar que inúmeras instituições estão reestruturando seus planos de estudos buscando a inserção do desenvolvimento das competências desejadas, bem como promovendo atividades que reforcem as competências na dimensão relacional, considerada uma dimensão tão pouco explorada.

A cada dia, os novos profissionais de matemática são levados a atuarem em cenários multidisciplinares, com especialistas de outras ciências que contribuíram com seus conhecimentos e experiências diversas, daí a necessidade de uma formação focada em uma nova mentalidade, adotando uma visão ampla do mundo em constante transformação.

Um dos grandes desafios do matemático do futuro será não apenas solucionar os problemas atuais, mas também estar preparado para atuar nos problemas da sociedade de forma eficaz e consciente, ou seja, encontrar a harmonia entre a matemática fundamental e básica e a matemática aplicada.(PANIAGUA et al., 2014)

A educação e a formação dos novos matemáticos exigem uma aprendizagem ativa, através da realização e análise de experiências sobre práticas didático-pedagógicas, onde os estudantes possam ser incentivados e passem a valorizar a apropriação do conhecimento de modo a desenvolverem seu potencial. 


\section{A Relação do Projeto Tuning América La- tina com as Diretrizes Curriculares Nacio- nais para a Licenciatura em Matemática}

\subsection{Introdução}

Este capítulo será destinado à comparação entre as DCN dos cursos de Licenciatura em Matemática e o Projeto Tuning América Latina, analisando as convergências e divergências entre as duas propostas. Para tanto se faz necessário assimilar o propósito do Parecer CNE/CES 1302/2001¹ (BRASIL, 2001a) o qual trata das DCN para os cursos em Matemática. O referido Parecer abrange tanto o curso de licenciatura quanto o curso de bacharelado, mas, como o foco aqui é a licenciatura, todas as referências sobre o documento se restringirão ao que compete à Licenciatura em Matemática.

No Brasil, desde 2001, todos os projetos pedagógicos dos cursos de graduação devem estar em concordância com as respectivas Diretrizes Curriculares Nacionais. Esse documento apresenta o perfil profissional de formação desejado, as competências as serem desenvolvidas ao longo da formação e os conteúdos curriculares a serem abordados. Para dar maior dinamismo ao texto será apresentado ao longo do capítulo o que propõem as DCN à medida que se fizer necessário para a comparação com o Projeto Tuning América Latina.

De acordo com o dicionário da Academia Brasileira de Letras, Academia Brasileira de Letras (2008, p. 446), a palavra diretrize significa conjunto de princípios e normas de procedimentos; diretiva; linha normativa de um procedimento. Com vistas na definição, as diretrizes são critérios que determinam e direcionam o desenvolvimento de algo. Assim é importante salientar que as DCN não são regras a serem seguidas, mas, sim, orientação para melhorias e transformações na formação do licenciado em matemática, assegurando uma formação adequada para os futuros professores de matemática.

\subsection{Perfil dos formandos}

Segundo as DCN são três as características de perfil esperadas que um licenciado em matemática deva alcançar:

- Visão de seu papel social de educador e capacidade de se inserir em diversas

1 O Parecer CNE/CES No 1302/2001 está no anexo II. 
Capítulo 4. A Relação do Projeto Tuning América Latina com as Diretrizes Curriculares Nacionais para a Licenciatura em Matemática

realidades com sensibilidade para interpretar as ações dos educandos;

- Visão da contribuição que a aprendizagem da Matemática pode oferecer à formação dos indivíduos para o exercício de sua cidadania;

- Visão de que o conhecimento matemático pode e deve ser acessível a todos, e consciência de seu papel na superação dos preconceitos, traduzidos pela angústia, inércia ou rejeição, muitas vezes ainda presentes no ensino-aprendizagem da disciplina;

É importante notar que as DCN propõem, a partir do perfil dos formandos, uma ampla formação para o profissional de matemática, não restringindo necessariamente apenas ao ensino da matemática. Os programas devem ser consolidados numa formação sólida dos conteúdos da matemática, mas sobre tudo capazes de prepararem o futuro matemático para os desafios do mercado de trabalho e todas as imposições que a docência exige.

Note que a primeira característica do perfil dos formandos trazida pelas DCN diz respeito à sensibilidade que o educador deve ter para agir diante das condições adversas de trabalho e toda a problemática de se inserir ativamente nas diversas áreas envolvidas no processo de ensino-aprendizagem. Isso se assemelha ao que propõe o projeto Tuning América Latina, seção 3.3, que traz o meta-prefil da área de matemática, destacando que:

O graduado em Matemática é um profissional com ética e sensibilidade humana, responsabilidade social e compromisso com a cidadania, disposto a aprender, atualizar-se constantemente e enfrentar novos problemas em diferentes áreas.

Observa-se aqui a primeira semelhança entre o Tuning América Latina e as DCN. A responsabilidade social é uma preocupação conjunta. Tanto as DCN quanto o projeto Tuning América Latina estão conscientes do compromisso que o futuro profissional de matemática deve ter com a formação do sujeito. Não somente a formação matemática mais principalmente a formação do indivíduo como parte integrante de uma sociedade.

De uma maneira mais sucinta, as DCN contemplam boa parte do meta-perfil da área de matemática traçado pelo Tuning América Latina, à medida que este destrincha em várias características o perfil do matemático. As DCN as engloba em uma só. Por exemplo, no que diz respeito à terceira característica das diretrizes sobre a superação dos preconceitos presentes no ensino-aprendizagem da disciplina, sinalizando que o futuro matemático deve agir para ultrapassar as barreiras da rejeição e da inércia que muitos estudantes trazem em relação à matemática, o meta-perfil do projeto Tuning América Latina para a área da matemática traz como características ações que o futuro profissional da área deve ter para lidar com essa problemática. Assim, se o matemático aplica os conhecimentos básicos para identificar, definir e solucionar com clareza os problemas matemáticos de maneira a facilitar a análise e o entendimento, ele está rompendo as barreiras da rejeição. Da mesma forma quando utiliza as tecnologias da informação e 
comunicação no processo de ensino-aprendizagem, está despertando o interesse do aluno e rompendo com a inércia existente.

O contato com os profissionais das outras disciplinas e, a interação com pessoas de diferentes equipes em contextos diversos são características desejáveis do futuro matemático. É o que evidencia o meta-perfil do Tuning América Latina, na seção 3.3, em: "Comunica-se com outros profissionais que não pertencem à área de matemática e presta assessoria para a aplicação da matemática em suas respectivas áreas de trabalho" e "Possui habilidades interpessoais para interagir com outras pessoas em diferentes contextos e para trabalhar em equipes multidisciplinares". Inserido nesse contexto dinâmico o profissional tem a visão que, a matemática trabalha simultaneamente com a formação do cidadão. Esta visão é tratada pelas DCN nas competências e habilidades, conforme é trazido na próxima seção. 


\subsection{Competências e habilidades}

Como já mencionado, o Brasil é um dos países que utiliza duas denominações para designar os cursos associados à matemática: Licenciatura e Bacharelado. Dessa forma, as DCN trazem competências e habilidades comuns relacionadas às duas habilitações e outras destinadas apenas aos licenciados.

De acordo com as DCN para os cursos de Matemática os currículos dos cursos de Bacharelado e Licenciatura em Matemática, devem ser elaborados de maneira a propiciar o desenvolvimento de 11 competências e habilidades, conforme descreve a Tabela 6 .

Tabela 6 - Competências e Habilidades das DCN para os cursos de Matemática.

\begin{tabular}{ll}
\hline Siglas & Competências e habilidades \\
\hline \hline CH01 & Capacidade de expressar-se escrita e oralmente com clareza e precisão. \\
\hline CH02 & Capacidade de trabalhar em equipes multidisciplinares. \\
\hline CH03 & $\begin{array}{l}\text { Capacidade de compreender, criticar e utilizar novas ideias e tecnologias para a } \\
\text { resolução de problemas. }\end{array}$ \\
\hline CH04 & $\begin{array}{l}\text { Capacidade de aprendizagem continuada, sendo sua prática profissional também fonte } \\
\text { de produção de conhecimento. }\end{array}$ \\
\hline CH05 & $\begin{array}{l}\text { Habilidade de identificar, formular e resolver problemas na sua área de aplicação, } \\
\text { utilizando rigor lógico-científico na análise da situação-problema. }\end{array}$ \\
\hline CH06 & Estabelecer relação entre a Matemática e outras áreas do conhecimento. \\
\hline CH07 & Conhecimento de questões contemporâneas. \\
\hline CH08 & $\begin{array}{l}\text { Educação abrangente necessária ao entendimento do impacto das soluções encontradas } \\
\text { num contexto global e social. }\end{array}$ \\
\hline CH09 & Participar de programas de formação continuada. \\
\hline CH10 & Realizar estudos de pós-graduação. \\
\hline CH11 & Trabalhar na interface da Matemática com outros campos de saber. \\
\hline
\end{tabular}

Fonte: Próprio autor com base Brasil (2001a), 2015.

Além dessas 11 competências comuns às duas habilitações, as DCN descrevem ainda mais seis competências e habilidades próprias do educador matemático. No que se refere ao licenciado em matemática, ele deverá ser capaz de desenvolver as seis competências descritas na Tabela 7 .

Para fazer distinção entre as competências trazidas aqui pelas DCN e aquelas sugeridas pelo projeto Tuning América Latina, foram usadas as notações: CH seguido de um número para designar as Competências e Habilidades comuns às duas habilitações e CHE para as Competências e Habilidades próprias do Educador matemático, como pode ser visto na Tabela 6 e na Tabela 7 .

Neste momento, vale retornar à Tabela 2 para relembrar as competências propostas pelo projeto Tuning e se familiarizar com a notação já estabelecida naquela seção, CG 
Capítulo 4. A Relação do Projeto Tuning América Latina com as Diretrizes Curriculares Nacionais para a Licenciatura em Matemática

Tabela 7 - Competências e Habilidades das DCN específicas do licenciado.

\begin{tabular}{ll}
\hline Siglas & Competências e habilidades \\
\hline \hline CHE01 & Elaborar propostas de ensino-aprendizagem de matemática para a educação básica. \\
\hline CHE02 & Analisar, selecionar e produzir materiais didáticos. \\
\hline CHE03 & Analisar criticamente propostas curriculares de Matemática para a educação básica. \\
\hline CHE04 & $\begin{array}{l}\text { Desenvolver estratégias de ensino que favoreçam a criatividade, a autonomia e a } \\
\text { flexibilidade do pensamento matemático dos educandos, buscando trabalhar com mais } \\
\text { ênfase nos conceitos do que nas técnicas, fórmulas e algoritmos. }\end{array}$ \\
\hline CHE05 & $\begin{array}{l}\text { Perceber a prática docente de Matemática como um processo dinâmico, carregado de } \\
\text { incertezas e conflitos, um espaço de criação e reflexão, onde novos conhecimentos são } \\
\text { gerados e modificados continuamente. }\end{array}$ \\
\hline CHE06 & Contribuir para a realização de projetos coletivos dentro da escola básica. \\
\hline
\end{tabular}

Fonte: Próprio autor,2015.

para competências gerais e CE para competências específicas, e a que será usada a partir de agora para as competências e habilidades propostas pelas DCN, conforme notação estabelecida no parágrafo anterior.

Mesmo não havendo a separação, por parte das DCN, entre competências gerais e competências específicas, é notório que ela reúne boa parte das competências propostas pelo Tuning América Latina, seja ela geral ou específica.

De acordo com as DCN, a primeira competência que o formando em matemática deve desenvolver é a "capacidade de expressar-se escrita e oralmente com clareza e precisão" - (CH 01), exatamente o que propõe o projeto Tuning América Latina, nas CG 06, CE 02, CE 03 e CE 18, mas de uma maneira mais específica e detalhada.

Desde o início, o Projeto Tuning foi pensado por equipes de diversas áreas e de maneira conjunta, e essa é uma característica forte que se retrata em várias das competências do projeto, seja geral ou específica da área. As competências CG 17 e CE 17 mostram claramente essa preocupação, "desenvolver nos futuros profissionais a capacidade de trabalho em equipe". Já as competências CE 14, CE 16 e CE 23 também buscam esse mesmo fim, mas de uma maneira mais sutil. Hoje a comunicação entre as mais diversificadas áreas é facilitada e estimulada e, diante desse cenário, os cursos devem ser elaborados com o intuito de desenvolver a capacidade de trabalhar em equipes multidisciplinares, precisamente o que diz a $\mathrm{CH} 02$.

$\mathrm{Na}$ tentativa de fazer um comparativo entre as competências propostas pelo projeto Tuning América Latina e as sugeridas pelas DCN, um quadro de equivalências foi desenvolvido(ver Tabela 8). Nele consta não somente as correspondências já mencionadas, mas todas as equivalências observadas entre esses dois documentos, seja ela uma equivalência direta ou indireta. 
Capítulo 4. A Relação do Projeto Tuning América Latina com as Diretrizes Curriculares Nacionais para a Licenciatura em Matemática

A equivalência direta entre as competências se dará quando existir o mesmo significado entre as duas, ou seja, tanto uma quanto a outra estão propondo a mesma ideia, já a equivalência indireta ocorrerá quando houver alguma relação, ou correspondência mais sutil entre elas. Aqui, lança-se mão da técnica de análise de conteúdo proposta por Bardin (2011, p.44) quando diz “A intenção da análise de conteúdo é a inferência de conhecimentos relativos às condições de produção (ou eventualmente, de recepção), inferência esta que recorre a indicadores (quantitativos ou não)".

Tabela 8 - Equivalência entre as competências.

\begin{tabular}{c|c|c}
\hline \multirow{2}{*}{ Diretrizes Curriculares Nacionais } & \multicolumn{2}{|c}{ Projeto Tuning América Latina } \\
\cline { 2 - 3 } & Direta & Indireta \\
\hline CH01 & CG06, CE18 & CE 03, CE 02 \\
\hline CH02 & CG17, CE17 & CE14, CE23, CE16 \\
\hline CH03 & & CG08, CG15, CE10 \\
\hline CH04 & CG10 & CE07 \\
\hline CH05 & CG15 & CG02, CE05, CE08, CE12 \\
\hline CH06 & CE16 & \\
\hline CH09 & CG10 & CG09 \\
\hline CH10 & & \\
\hline CH11 & CE16 & \\
\hline CHE01 & CE21 & \\
\hline CHE04 & CG14, CG16, CG24 & CG13, CG27, CE08, CE22 \\
\hline
\end{tabular}

Fonte: Próprio autor, 2015.

Ressalta-se que nem todas as competências foram relacionadas no quadro de equivalência, mas, por outro lado, muitas delas se repetiram. No geral, o projeto Tuning América Latina compreende 50 competências e as DCN, menos da metade, apenas 17. A tabela de equivalência mostra que uma competência das DCN pode corresponder a quatro ou cinco competências do Tuning América Latina. Isso porque, na grande maioria, as competências trazidas pelo projeto Tuning são mais esmiuçadas, mas isso não é uma característica geral.

Por exemplo, a competência geral 10 do Tuning é uma confluência das CH 09 e $\mathrm{CH}$ 04. Aqui as DCN fazem uma partição na formação continuada. A CH 04 trata da aprendizagem continuada usando, para isso, a prática profissional e a $\mathrm{CH} 09$ vem expondo a preocupação com a participação dos futuros matemáticos em programas de formação continuada. O mesmo ocorre ao analisar CH 06 e CH 11, as duas se fundem na competência específica 16 - CE 16 do Tuning.

O desenvolvimento de uma competência quer seja geral ou específica, de uma formação geral ou apenas do educador de matemática, está vinculado, de modo simultâneo 
Capítulo 4. A Relação do Projeto Tuning América Latina com as Diretrizes Curriculares Nacionais para a Licenciatura em Matemática

e natural, ao desenvolvimento de outras competências. Assim favorecendo-se o desenvolvimento de algumas delas, várias outras competências são estimuladas simultaneamente.

Por ser um projeto internacional, o Tuning América Latina contempla algumas competências voltadas para a diversidade cultural entre os vários países participantes, como, por exemplo, as competências CG 21, CG 22, CG 23 e CG 26. Todas elas propõem questões socioculturais, de contextos internacionais e éticos, questões que, naturalmente, não são apreciadas pelas DCN por se tratar de um documento de abrangência apenas nacional.

No âmbito do Tuning América Latina, o desenvolvimento da competência geral (CG 15) - "Capacidade para identificar, apresentar e resolver problemas", está vinculado, entre outras, às competências: CG 01 - "Capacidade de abstração, análise e síntese"; CG 04 - "Conhecimento sobre a área de estudo e a profissão"; CG 14 - "Capacidade criativa". $\mathrm{Na}$ esfera das DCN, a competência CH 03 - "Capacidade de compreender, criticar e utilizar novas ideias e tecnologias para a resolução de problemas", está relacionada ao desenvolvimento de outras competências tais como: CH 05 - "Habilidade de identificar, formular e resolver problemas na sua área de aplicação, utilizando rigor lógico-científico na análise da situação-problema"; CHE 04 - "Desenvolver estratégias de ensino que favoreçam a criatividade, a autonomia e a flexibilidade do pensamento matemático dos educandos, buscando trabalhar com mais ênfase nos conceitos do que nas técnicas, fórmulas e algoritmos"; entre outras.

Diante de todo esse contexto e tendo em vista a similaridade entre várias das competências propostas pelo projeto Tuning América Latina e pelas DCN, verifica-se que existe uma relação vertical e horizontal entre os dois projetos. Horizontalmente, no sentido de que as competências de um mesmo projeto estão conectadas entre si e, verticalmente, pois, como vimos, as DCN e o projeto Tuning América Latina estão convergindo para o mesmo ponto. A confluência entre eles não está apenas nas competências e no perfil do egresso, mas também nos conteúdos curriculares.

\subsection{Conteúdos Curriculares}

Segundo o Parecer CNE/CES 1302/2001 (BRASIL, 2001a), cada instituição de ensino superior tem a autonomia da organização do seu próprio currículo, embora essa autonomia esteja sujeita às orientações descritas no referido Parecer. Os currículos devem ser pensados em concordância com o perfil que se deseja do egresso, bem como as competências que se anseia desenvolver no futuro matemático. E para qualquer que seja a formação no campo de atuação da matemática alguns conteúdos comuns são assegurados pelas Diretrizes Curriculares Nacionais.

Conforme as DCN, os conteúdos comuns a todos os cursos de Licenciatura são: 
- Cálculo Diferencial e Integral

- Álgebra Linear

- Fundamentos de Análise

- Fundamentos de Álgebra

- Fundamentos de Geometria

- Geometria Analítica

- Conteúdos matemáticos presentes na educação básica nas áreas de Álgebra, Geometria e Análise

- Conteúdos de áreas afins à matemática, que são fontes originadoras de problemas e campos de aplicação de suas teorias

- Conteúdos da Ciência da Educação, da História e Filosofia das Ciências e da Matemática.

Fazendo um paralelo com os conteúdos recomendados pelo projeto Tuning América Latina, Tabela 5, observa-se que lá é explicitado dentro de cada conteúdo uma gama de subconteúdos, o que não ocorre aqui nas DCN. Contudo, todos os conteúdos de ambos os documentos têm o seu equivalente, alguns possuem a mesma nomenclatura, como a Álgebra Linear, o Cálculo e a Geometria Analítica, outros possuem nomes diferentes, mas, teoricamente, trata-se do mesmo conteúdo, como no caso da Análise Matemática, aqui entendida como Fundamentos de Análise, a Geometria Elementar e a Álgebra Abstrata trazida pelas DCN como Fundamentos de Geometria e Fundamentos de Álgebra, respectivamente.

Todos esses conteúdos podem ser distribuídos ao longo do curso conforme currículo proposto pela IFES, que também fica responsável por determinar os conteúdos da Ciência da Educação, da História e Filosofia das Ciências e Matemática. É também de responsabilidade de cada instituição, segundo as DCN, disponibilizar o acesso às tecnologias úteis para o ensino da matemática, seja por meio de uma formação complementar específica na área da computação, seja difundida ao longo dos conteúdos matemáticos.

Os conhecimentos de Física, a Geometria Diferencial e o estudo da Probabilidade e Estatística são os três conteúdos curriculares descritos pelas DCN que divergem dos descritos pelo Tuning América Latina, isso porque, nas DCN, eles são considerados conteúdos exclusivos do bacharelado, uma vez que, no Brasil, existe a segregação entre as duas habilitações, diferentemente do que ocorre no Tuning América Latina devido à sua abrangência universal na formação do matemático.

No que diz respeito às atividades complementares e estágios tanto as DCN quanto o projeto Tuning América Latina ressaltam a importância de desenvolver atividades que 
Capítulo 4. A Relação do Projeto Tuning América Latina com as Diretrizes Curriculares Nacionais para a Licenciatura em Matemática

complementem a visão do futuro pesquisador ou insira o educador matemático na realidade da docência. As atividades complementares podem ser feitas por meio da produção de monografias, participação em atividades de extensão universitária e em programas de iniciação científica e à docência.

Para as DCN, o estágio é considerado essencial nos cursos de formação de professores, uma vez que possibilita ao futuro professor desenvolver a responsabilidade por uma série de ações gradativamente complexas e, com isso, tomar ciência dos processos formadores. Toda essa aprendizagem deve ser supervisionada por profissionais de competência reconhecida.

No geral, as DCN orientam a formulação do projeto pedagógico para os cursos de matemática e, segundo a Resolução CNE/CES 3/2003² (BRASIL, 2003), o projeto pedagógico deve explicitar: o perfil dos formandos, as competências e habilidades de caráter geral e comum e aquelas de caráter específico, os conteúdos curriculares de formação geral e os conteúdos de formação específica, o formato de estágio, as característica das atividades complementares, as estruturas do curso e as formas de avaliação, além da carga horária do curso, que, por sua vez, deverá obedecer ao disposto na resolução CNE/CP 02/2002 3 (BRASIL, 2002b), que normatiza a carga horária das licenciaturas.

\subsection{Carga horária do curso de Matemática}

A carga horária dos cursos licenciatura, de graduação plena, de formação de professores da Educação Básica em nível superior, será instituída através da integralização de, no mínimo, 2800 (duas mil e oitocentas) horas, conforme Art. $1^{\circ}$ da legislação referente à carga horária dos cursos de licenciaturas Resolução CNE/CP 02/2002, nas quais a articulação teoria-prática garanta, nos termos dos seus projetos pedagógicos, as seguintes dimensões dos componentes comuns:

I - 400 (quatrocentas) horas de prática como componente curricular, vivenciadas ao longo do curso;

II - 400 (quatrocentas) horas de estágio curricular supervisionado a partir do inicio da segunda metade do curso;

III - 1800 (mil e oitocentas) horas de aulas para conteúdos curriculares de natureza científico-cultural;

IV - 200 (duzentas) horas para outras formas de atividades acadêmico-científicoculturais.

A organização de uma proposta pedagógica de um curso de formação de professores deve está intrinsecamente fundada no que estabelece as DCN e as demais legislações 
Capítulo 4. A Relação do Projeto Tuning América Latina com as Diretrizes Curriculares Nacionais para a Licenciatura em Matemática

referentes ao tema. No próximo capítulo será analisado um projeto pedagógico de uma instituição de ensino superior fazendo um paralelo com a proposta Tuning. 


\title{
5 Análise de um Projeto Pedagógico de um Curso de Licenciatura em Matemática de uma Instituição de Ensino Superior
}

\subsection{Introdução}

A proposta para este capítulo é verificar a proximidade do Projeto Pedagógico do Curso (PPC) de Licenciatura em Matemática de uma Instituição Federal de Ensino Superior (IFES) com o Projeto Tuning América Latina. Pretende-se aqui analisar algumas peculiaridades do cumprimento do que se estabelecem as Diretrizes Curriculares Nacionais e a Resolução CNE/CP 2/2002. (BRASIL, 2002b)

Antes de começar a análise do PPC de Licenciatura em Matemática faz-se necessário entender o que é um Projeto Pedagógico. Nas palavras de Godotti, trazidas por Veiga (2008, p.12), projetar significa

tentar quebrar um estado confortável para arriscar-se, atravessar um período de instabilidade e buscar uma nova estabilidade em função da promessa que cada projeto contém de estado melhor do que o presente. Um projeto educativo pode ser tomado como promessa frente a determinadas rupturas.

A pesquisadora completa

\begin{abstract}
o projeto político-pedagógico tem a ver com a organização do trabalho pedagógico em dois níveis: como organização de toda a escola e como organização da sala de aula, incluindo sua relação com o contexto social imediato, procurando preservar a visão de totalidade.
\end{abstract}

Nos documentos federais sobre a educação, adotam-se termos variados para esse documento: projeto pedagógico, proposta pedagógica, ou, ainda, projeto político pedagógico. A Lei de Diretrizes e Bases da Educação Nacional (LDB) ${ }^{1}$ de 1996 (ver Brasil (1996)) traz apenas duas das expressões: proposta pedagógica (Art.12 e 13) e projeto pedagógico (Art 14, inciso I). Já o termo projeto político pedagógico não é usado na LDB, mas alguns especialistas explicam que o adjetivo político foi inserido para mostrar que a ação pedagógica está imersa em atos de cidadania, sendo, assim, um ato político.

$1 \quad$ Lei 9394, de 20/12/96, conhecida por Lei de Diretrizes e Bases da Educação Nacional pode ser lida na íntegra em < http://portal.mec.gov.br/arquivos/pdf/ldb.pdf $>$. 
Capítulo 5. Análise de um Projeto Pedagógico de um Curso de Licenciatura em Matemática de uma Instituição de Ensino Superior

Por outro lado, há os que defendem que não há necessidade da inserção da palavra político, pois o conceito pedagógico já agrega o elemento político, uma vez que a proposta pedagógica se faz fundada em ações transformadoras projetadas coletivamente, buscando o melhor desenvolvimento da educação.

O PPC deve ser um documento orientador consolidado em base sólida, capaz de assegurar a realização de um curso que almeje a qualidade do ensino e o comprometimento com os ideais institucionais. É durante a fase de planejamento do PPC que os responsáveis devem ponderar o tipo de cidadão que eles desejam formar para a sociedade.

O PPC da Licenciatura em Matemática foi escolhido de uma IFES com tradição na formação de qualidade de seus matemáticos. Nessa IFES, a formação dos professores de matemática se dá mediante a licenciatura plena, o que os habilitam a atuarem na segunda fase do Ensino Fundamental ou no Ensino médio. O PPC analisado foi reestruturado em 2011 e colocado em prática no primeiro semestre de 2012. Segundo a instituição, essa reestruturação foi feita devido à reorganização dos programas educacionais com ênfase no desenvolvimento das capacidades do aluno e suas competências. Tem-se aqui a primeira semelhança com o Tuning América Latina, um PPC alterado para ser estruturado dando destaque às competências dos alunos.

A análise do PPC de Licenciatura em Matemática da IFES escolhida será feita explorando-se as convergências e divergências deste com as propostas do Tuning América Latina e seguindo o disposto no Art. $2^{\circ}$ da Resolução CNE/CES 3/2003 (BRASIL, 2003), que diz:

Art. $2^{\circ} \mathrm{O}$ projeto pedagógico de formação profissional a ser formulado pelo curso de Matemática deverá explicitar:

a) O perfil dos formandos;

b) As competências e habilidades de caráter geral e comum e aquelas de caráter específico;

c) Os conteúdos curriculares de formação geral e os conteúdos de formação específica;

d) O formato dos estágios

e) As características das atividades complementares;

f) A estrutura do curso;

g) As formas de avaliação.

A partir de agora, sempre que se fizer referência ao PPC de Licenciatura em Matemática estará se referindo ao PPC de Licenciatura em Matemática da IFES escolhida para o estudo e será usado apenas o termo PPC. 
Capítulo 5. Análise de um Projeto Pedagógico de um Curso de Licenciatura em Matemática de uma Instituição de Ensino Superior

\subsection{Perfil dos formandos}

O perfil do formando relata as características que o profissional do ensino deve apresentar. No PPC em análise, ele vem com o nome de Perfil do egresso e descreve dez características desejáveis do profissional do ensino em matemática:

- Possuir sólida formação em conhecimentos específicos para realizar uma prática educativa de ensino em matemática de qualidade, tendo ciência da importância do professor no processo de aprendizagem do aluno e do papel social do educador;

- Compreender as áreas de conhecimento que serão objeto de sua atuação pedagógica, os contextos e as temáticas do currículo escolar para planejar, organizar, gerir e avaliar situações didáticas e projetos de ensino eficazes para a aprendizagem escolar;

- Gerenciar a relação entre o saber científico e a dimensão cultural, social, histórica, política e econômica da educação necessária ao desenvolvimento das pessoas, da sociedade e na construção da cidadania;

- Saber articular de forma integrada conteúdo, métodos, objetivos, recursos e estratégias de ensino que contribuam no desenvolvimento de raciocínio lógico, da imaginação, da criatividade e da capacidade de abstração do aluno;

- Promover atividades de ensino focadas na aprendizagem do saber matemático mediante articulações entre conceitos, linguagens e representações e em função do nível cognitivo dos alunos, respeitando a sua diversidade pessoal, social e cultural.

- Propiciar o trabalho em equipe ou dinâmica de grupos como estímulo para a comunicação oral, a leitura crítica, a formulação de hipóteses, o confronto e o respeito a diferentes pontos de vista, a comparação e o estabelecimento de relações, observação, argumentação, organização, análise, síntese, questionamento e pesquisa, exercício do pensamento crítico e reflexivo.

- Favorecer a convivência entre os alunos com o fortalecimento da tolerância, solidariedade, cooperação, convivência com a diversidade.

- Valorizar a posição central do aluno como construtor do seu conhecimento, assumindo como educador o papel de orientador e guia dos trabalhos, mediante o exercício das funções de organizador, facilitador, mediador, incentivador, avaliador.

- Conduzir ações educativas que estimulem nos alunos a valorização do conhecimento e dos bens culturais e que contribuam para o desenvolvimento das competências dos alunos de enfrentar desafios, opinar, criar, raciocinar, agir de forma autônoma, adquirir confiança na própria capacidade de pensar e encontrar soluções;

- Realizar pesquisa e avaliação no âmbito da sua própria prática docente.

A responsabilidade social é algo inerente ao trabalho do educador, o qual, ao atuar 
Capítulo 5. Análise de um Projeto Pedagógico de um Curso de Licenciatura em Matemática de uma Instituição de Ensino Superior

em diversas situações, tem a obrigação de encarar com receptividade seu papel na formação do indivíduo como cidadão. Isso é retratado na primeira característica do perfil do egresso trazida aqui pelo PPC e que está em concordância com as DCN, na seção 4.2, e com Projeto Tuning América Latina, na seção 3.3. Todos os três documentos começam trazendo o perfil do egresso com a característica considerada essencial ao educador: a visão do seu papel social como educador.

Recordando o que diz Bardin (2011, p.44) "a intenção da análise de conteúdo é a inferência de conhecimentos relativos às condições de produção (ou, eventualmente, de recepção), inferência esta que recorre a indicadores (quantitativos ou não)". E, ainda, Bardin (2011, p.148) diz "Classificar elementos em categorias impõe a investigação do que cada um deles tem em comum com outros. O que vai permitir o seu agrupamento é a parte comum existente entre eles".

Lançando-se mão do critério de categorização de Bardin esse agrupamento é efetuado em razão das características comuns destes elementos. De agora em diante, essa será a linha de análise entre PPC, o projeto Tuning América Latina e as DCN.

O Tuning América Latina, nos dois primeiros itens do meta-perfil, seção 3.3, traz:

- O graduado em Matemática é um profissional com ética e sensibilidade humana, responsabilidade social e compromisso com a cidadania, disposto a aprender, atualizar-se constantemente e enfrentar novos problemas em diferentes áreas.

- Possui sólida formação no que diz respeito a conhecimentos, habilidades e destrezas próprias de sua área de estudo e de sua profissão, domina os conceitos básicos da matemática superior e elabora e devolve argumentações lógicas com uma identificação clara de hipóteses e conclusões.

Essas duas características foram convergidas na primeira característica do PPC, a expressão "Possuir sólida formação em conhecimentos específicos para realizar uma prática educativa de ensino em matemática de qualidade...", equivale a "Possui sólida formação no que diz respeito a conhecimentos, habilidades e destrezas próprias de sua área de estudo e de sua profissão..." e, a segunda parte, "tendo ciência da importância do professor no processo de aprendizagem do aluno e do papel social do educador" é equivalente ao meta perfil: "O graduado em Matemática é um profissional com ética e sensibilidade humana, responsabilidade social e compromisso com a cidadania...".

A terceira característica do PPC: "Gerenciar a relação entre o saber científico e a dimensão cultural, social, histórica, política e econômica da educação necessária ao desenvolvimento das pessoas, da sociedade e na construção da cidadania", pode ser comparada com a segunda relatada nas DCN, seção 4.2: "Visão da contribuição que a aprendizagem da Matemática pode oferecer à formação dos indivíduos para o exercício de sua cidadania". Note que o texto do PPC é mais descritivo ao passo que, nas DCN, 
Capítulo 5. Análise de um Projeto Pedagógico de um Curso de Licenciatura em Matemática de uma Instituição de Ensino Superior

ele possui um caráter mais amplo, deixando apenas a proposta para que cada instituição descreva o perfil com a sua abordagem.

Outra aproximação ocorre entre a sexta característica traçada pelo meta-perfil Tuning: "Se expressa correta e eficazmente em forma oral e escrita, domina a linguagem da matemática e apresenta os raciocínios matemáticos e suas conclusões com clareza, precisão e de forma apropriada para o público alvo", e a quarta trazida pelo PPC: "Saber articular de forma integrada conteúdo, métodos, objetivos, recursos e estratégias de ensino que contribuam no desenvolvimento de raciocínio lógico, da imaginação, da criatividade e da capacidade de abstração do aluno".

Em contrapartida, as demais características evidenciam capacidades decorrentes do conhecimento adquirido durante a formação, condiz com ações que devem ser desenvolvidas pelos formandos na prática da docência, e isso seria enquadrado mais adequadamente nas competências. Em Rabelo (2013, p.188), o conceito de competência é destacado segundo os estudiosos Deluiz, Le Boterf, Perrenoud, Wittorski e Zarifian

\footnotetext{
Competência é a capacidade do sujeito de selecionar organizar, mobilizar e utilizar, intencionalmente, recursos (conhecimentos, saberes, habilidades, esquemas mentais, afetos, crenças, princípios, posturas, comportamentos e outros processos psicológicos ou comportamentais), nas relações e em ação, para o enfrentamento de uma situação-problema específica, não apenas na dimensão técnico-especializada, mas também na dimensão sociopolítica, comunicacional e de inter-relações pessoais.
}

Fundamentado neste conceito de competência e explorando cautelosamente o seu significado e as características trazidas no perfil do egresso do PPC, é possível observar esse fato curioso. As sete últimas características melhor se assemelham com competências do que propriamente características do perfil do egresso. A Tabela 9 a seguir mostra dois exemplos dessa similaridade, que ocorrem entre a sexta característica do perfil do egresso do PPC e as competências das DCN, e entre a sétima característica do perfil do egresso e as competências gerais do Tuning América Latina.

Observa-se que a proximidade entre as características do perfil do egresso do PPC e as competências não se restringem às competências gerais, mas também às específicas das DCN como mostra o quadro anterior. As demais características também se relacionam de maneira mais indiretamente com as competências. 
Capítulo 5. Análise de um Projeto Pedagógico de um Curso de Licenciatura em Matemática de uma Instituição de Ensino Superior

Tabela 9 - Exemplos de similaridade entre o perfil do egresso do PPC e as competências das DCN e do Tuning.

\begin{tabular}{|c|c|}
\hline Perfil do egresso do PPC & Competências das DCN \\
\hline $\begin{array}{l}\text { Propiciar o trabalho em equipe ou dinâmica de } \\
\text { grupos como estímulo para a comunicação oral, a } \\
\text { leitura crítica, a formulação de hipóteses, o con- } \\
\text { fronto e o respeito a diferentes pontos de vista, } \\
\text { a comparação e o estabelecimento de relações, } \\
\text { observação, argumentação, organização, análise, } \\
\text { síntese, questionamento e pesquisa, exercício do } \\
\text { pensamento crítico e reflexivo. }\end{array}$ & $\begin{array}{l}\text { CH06 - Estabelecer relação entre a Matemática e } \\
\text { outras áreas do conhecimento. CH11 - Trabalhar } \\
\text { na interface da Matemática com outros campos de } \\
\text { saber. CHE05 - Perceber a prática docente de Ma- } \\
\text { temática como um processo dinâmico, carregado } \\
\text { de incertezas e conflitos, um espaço de criação e } \\
\text { reflexão, onde novos conhecimentos são gerados e } \\
\text { modificados continuamente. }\end{array}$ \\
\hline Perfil do egresso do PPC & Competências gerais do Tuning \\
\hline $\begin{array}{l}\text { Favorecer a convivência entre os alunos com o } \\
\text { fortalecimento da tolerância, solidariedade, coope- } \\
\text { ração, convivência com a diversidade. }\end{array}$ & $\begin{array}{l}\text { CG05 - Responsabilidade social e compromisso ci- } \\
\text { dadão. CG21 - Compromisso com o meio sociocul- } \\
\text { tural. CG22 - Valorizar e respeitar a diversidade } \\
\text { e a multiculturalidade. }\end{array}$ \\
\hline
\end{tabular}

Fonte: Próprio autor, 2015.

\subsection{Competências Gerais e específicas}

O PPC não apresenta competências próprias, limita-se a listar as competências das Diretrizes Curriculares Nacionais para a formação de Professores da Educação Básica, em nível superior, curso de licenciatura, de graduação plena - Parecer CNE/CP 09/20012 (BRASIL, 2001b), que contempla um total de 28 competências divididas em seis categorias. Naturalmente, era de se esperar que a IFES pesquisada inserisse especificidades relacionadas à sua história e experiência, principalmente por se tratar de uma instituição pioneira em ações pedagógicas inovadoras relativas à formação de professores de matemática. Mesmo sem explicitar aqui as 28 competências relacionadas no PPC, é possível verificar que elas guardam relação direta com as competências gerais e específicas do Tuning América Latina. Neste momento, vale retornar às seções 2.5 e 3.2 para relembrar as competências propostas pelo Tuning América Latina para, assim, dividi-las nas seis categorias propostas no PPC.

$\left.1^{\mathrm{a}}\right)$ Competências referentes ao comprometimento com os valores inspiradores da sociedade democrática: CG 05, CG 21, CG 22, CG 26, CG 27.

$2^{\mathrm{a}}$ ) Competências referentes à compreensão do papel social da escola; CG 05, CG 21, CG 25.

$3^{\text {a }}$ ) Competências referentes ao domínio dos conteúdos a serem socializados, de seus significados em diferentes contextos e de sua articulação interdisciplinar: CG 08, CG 02, CG 04, CG 06, CG 17, CE 01, CE 16, CE 17.

$4^{\mathrm{a}}$ ) Competências referentes ao domínio do conhecimento pedagógico; CG 03, CG

2 Parecer CNE/CP 09/2001 disponível em <http://portal.mec.gov.br/cne/arquivos/pdf/009.pdf > acesso em 12 maio 2015 
Capítulo 5. Análise de um Projeto Pedagógico de um Curso de Licenciatura em Matemática de uma Instituição de Ensino Superior

14, CG 16, CE 08, CE 09, CE 12, CE 19, CE 22.

$5^{\mathrm{a}}$ ) Competências referentes ao conhecimento de processos de investigação que possibilitem o aperfeiçoamento da prática pedagógica; CG 09, CG 10, CG 18.

$6^{\text {a }) ~ C o m p e t e ̂ n c i a s ~ r e f e r e n t e s ~ a o ~ g e r e n c i a m e n t o ~ d o ~ p r o ́ p r i o ~ d e s e n v o l v i m e n t o ~ p r o f i s s i-~}$ onal. CG 07, CG 11, CG 19, CG 25, CE 21.

No Art. $6^{\circ}$ da Resolução CNE/CP 1/2002³ (BRASIL, 2002b), está descrito que, na construção do projeto pedagógico, devem ser consideradas essas seis categorias de competências, mas, no $\S 1^{\circ}$ deste mesmo artigo, ressalta que o conjunto das competências enumeradas não esgota tudo que uma escola possa oferecer aos seus alunos e, no $\S 2^{\circ}$, destaca que as referidas competências devem ser contextualizadas e complementadas pelas competências específicas próprias de cada etapa e modalidade da educação básica e de cada área do conhecimento a ser contemplada na formação. Neste aspecto, observa-se que, contextualizar e complementar são instrumentos que todos os Projetos Pedagógicos deveriam explorar como ferramenta potencial para dar identidade ao curso e à instituição.

\subsection{Conteúdos Curriculares}

A instituição incorpora uma divisão de conteúdo por seis categorias, incluindo os estágios, assim denominadas:

(1) Formação matemática: Cálculo diferencial e integral de funções reais de uma e de várias variáveis; Cálculo vetorial; Álgebra Linear; Estruturas algébricas; Teoria dos números; Geometria Analítica; Geometria Euclidiana e não-euclidiana; Análise Real; Análise Complexa.

(2) Formação em áreas científicas afins: Computação; Estatística; Física e Probabilidade.

(3) Formação matemática para a educação básica: Álgebra, Geometria, Estatística e Análise.

(4) Formação Pedagógica: Psicologia da Educação, Didática Fundamental, Didática da Matemática, Organização Educacional.

(5) Formação em tecnologias da educação: Estudo e montagem de materiais, modelos e instrumentos de laboratório que servem de suporte manipulativo no ensino-aprendizagem dos conceitos matemáticos; Exploração e prática dos recursos audiovisuais e das novas tecnologias aplicadas na educação; Experimentação e aplicação de softwares específicos para o ensino da Matemática.

3 Resolução CNE/CP 1/2002 disponível em < http://portal.mec.gov.br/cne/arquivos/pdf/rcp01_02. pdf $>$ acessado em 12 maio 2015) 
Capítulo 5. Análise de um Projeto Pedagógico de um Curso de Licenciatura em Matemática de uma Instituição de Ensino Superior

(6) Estágios: serão tratados na seção 5.6.

No geral, os conteúdos do projeto Tuning America Latina, capítulo 3, seção 3.4, em comparação a estes relatados no PPC estão em paridade. Contudo, ocorre uma disparidade com Cálculo Vetorial, Teoria dos números e Geometria não euclidiana que não foram abordados pelo Tuning America Latina. No entanto, o Cálculo Vetorial é um conteúdo tratado em Álgebra Linear, como aponta a tabela 5, seção 3.4.

A Física foi a única área afim contemplada entre os conteúdos curriculares no projeto Tuning América Latina para a área de matemática; por outro lado, o PPC concebe familiarização em mais três grandes áreas do conhecimento: computação, estatística e probabilidade. Conforme orientação das DCN, cada IES pode organizar seus PPC de modo a proporcionar ao licenciado uma formação complementar que o leve a trabalhar na interface da matemática com outras áreas do saber, propiciando aos futuros professores maior circulação entre as áreas e melhor compreensão de suas inter-relações.

Os conteúdos que compõem o núcleo pedagógico do curso são voltados a motivar o desenvolvimento da prática do magistério, através de ferramentas importantes, promovendo aos futuros professores uma continuidade do processo de ensino-aprendizagem. Desses conteúdos, apenas Didática da Matemática foi mencionado pelo Tuning América Latina, mesmo trazendo a descrição ampla de que este conteúdo deve está de acordo com as características presentes na instituição ou em disciplinas em estágios de modalidade, o projeto deixa pendentes os conteúdos da formação pedagógica.

Todos os conteúdos descritos pelo Tuning América Latina, ou os trazidos pelo PPC em conformidade com as DCN, compõem alicerce para o pleno conhecimento na área de atuação no ensino da matemática. Mais um ponto de convergência, entre os muitos já expostos até agora.

\subsection{Carga horária}

Segundo o PPC, a estrutura curricular da Licenciatura em Matemática da IFES incorpora disciplinas obrigatórias e optativas, bem como atividades complementares, divididas em oito semestres. A grade curricular do curso possui uma carga horária total de 2820 (duas mil oitocentas e vinte) horas, para atender a exigência da legislação referente à carga horária dos cursos de licenciaturas, de acordo com o exposto na seção 4.5 do capítulo 4 .

No Brasil, o ano letivo regular deve ter no mínimo duzentos dias letivo de trabalho acadêmico efetivo, conforme art. 47 da Lei de Diretrizes e Base da Educação Nacional (BRASIL, 1996). Esses 200 dias letivos, expressos em semanas, daria 40 semanas de trabalho acadêmico durante um ano, o que está dentro da variação observada pelo Tuning 
Capítulo 5. Análise de um Projeto Pedagógico de um Curso de Licenciatura em Matemática de uma Instituição de Ensino Superior

América Latina, no capítulo 2, seção 2.3.1.

O fluxo curricular do PPC mostra um número total de créditos em um ano acadêmico variando entre 46 e 48 créditos, isso é um pouco abaixo dos 60 créditos anuais estabelecidos pelo Tuning América Latina, o que é devido à abordagem dada pelo Tuning América Latina à carga de trabalho do aluno em tempo completo. Não foi encontrada no PPC menção ao número de horas semanais que o aluno deve dispor para o bom desempenho no estudo e, para que seja possível a comparação com a proposta Tuning, é necessário ter um quantitativo das horas de trabalho semanal do aluno. Para tanto, como o PPC não faz distinção entre as horas semanais de trabalho que o estudante dispõe para estudo e as horas efetivas de estudo sob supervisão do professor, será usado apenas os registros que consta no PPC das horas efetivas de estudo sob interação direta do professor.

No fluxo de cada semestre, consta uma carga horária total de 360 hora/aula, e isso condiz com as atividades sob supervisão direta do professor. Então,

$$
\frac{360 \text { horas semestrais }}{20 \text { semanas }}=18 \text { horas de trabalho semanais. }
$$

Conforme a fórmula para o CLAR (Credito Latino Americano de Referencia)(ver Equação 2.1) e usando os valores disponíveis no PPC, tem-se

$$
\frac{40.18}{48}=15 \text { h/crédito. }
$$

$\mathrm{Ou}$

$$
\frac{40.18}{46}=15,65 \text { h/crédito }
$$

Ou seja, a carga de trabalho semanal do estudante está variando entre 15 e 15,65 horas cronológicas de trabalho do estudante, valor aquém do sugerido pelo Tuning América Latina. Isso ocorre, pois o PPC não prevê o tempo que o estudante se dedica à aprendizagem, sem a supervisão do professor. Dessa forma, segundo o PPC, as horas de trabalho do estudante durante o ano ficaria estabelecida em 720 horas, exatamente metade do limite mínimo estabelecido na faixa de variabilidade aceitável pelo Tuning América Latina.

Vale lembrar que um dos diferenciais do CLAR, proposto pelo Tuning América Latina, é distribuir os créditos entre todos os componentes previstos no Projeto Pedagógico do Curso, e não somente aquelas que possuem interação direta professor/estudante.

Durante todo o processo de formação, o estudante se presta a atividades acadêmicas dentro e fora da instituição, com e sem a orientação do professor, e, para tanto, é necessário que ele desprenda tempo para concretizar cada aprendizado. Este é um ponto de vista inovador do projeto Tuning América Latina e, frente aos dados do PPC, mostra que o 
Capítulo 5. Análise de um Projeto Pedagógico de um Curso de Licenciatura em Matemática de uma Instituição de Ensino Superior

tempo oriundo de atividades sem a interação direta do professor requer, em média, a mesma quantidade de horas que as advindas das atividades com interação direta.

\subsection{Estágios}

A preparação para a docência na área de matemática deve fazer parte do princípio segundo o qual é papel da educação contribuir com o processo de transformação social e construção da cidadania. O estágio supervisionado trabalha nessa linha de transformação com vistas a exigir do egresso uma sólida formação para lidar com as dificuldades que se colocam, hoje, a prática da educação.

O estágio supervisionado trazido no PPC é vivenciado em seis componentes curriculares, onde os discentes têm a oportunidade de conhecer na prática o seu futuro ambiente de trabalho e atuar nele sob a supervisão de um professor da IFES. As componentes são desenvolvidas em escolas públicas conveniadas a IFES.

Segundo o PPC, o estágio será caracterizado mais especificamente por desenvolver atividades tais como: observação de aulas do professor de uma turma na escola pública conveniada; coparticipação com o professor da turma em atividades de sala de aula; regência de uma turma escolar; observação da regência de aulas do colega; reforço escolar em horário extraclasse, minicurso sobre temas do programa escolar; reunião de orientação semanal com o professor da IFES responsável pela componente curricular; apresentação de portfólio com os planos de aula e regência e do minicurso, pesquisas realizadas, artigos estudados, relatos de experiências e resolução de problemas relacionados com a prática escolar desenvolvida. Algumas dessas atividades são realizadas de maneira concomitante, portanto os professores concentram dedicação e tempo considerável no trabalho realizado na instituição de ensino onde desenvolve a regência escolar. Na visão do Tuning América Latina, essas atividades são todas suscetíveis a aquisição de créditos; em contrapartida, no PPC, os créditos são computados apenas nas atividades sob a supervisão direta do professor da IFES ou da escola conveniada.

\subsection{Atividades Complementares}

Não somente de formação básica se faz um bom profissional, é também necessário despertar o espírito investigativo, a curiosidade científica, bem como acompanhar as rápidas mudanças tecnológicas, atualizar-se e desenvolver a interdisciplinaridade do conhecimento. Para tanto, a qualidade do ensino da matemática está vinculada a todas essas formas de desenvolvimento humano e científico.

A lista de atividades complementares mencionada no PPC é bem variada, a IFES disponibiliza ao aluno de graduação projetos, programas e monitorias tais como: 
- Programa de Educação Tutorial (PET);

- Programa Institucional de Bolsas de Iniciação Científica (PIBIC);

- Programa Institucional de Bolsas de Iniciação à Docência (PIBID);

- Projeto de Extensão de Ação Contínua: Integração Universidade Escola no Laboratório de Ensino de matemática (UniEscola);

- Projeto de extensão de Ação Contínua: Serviços de Atendimento Matemático à Comunidade (SAMAC);

- Monitorias.

Todos esses programas contam com número determinado de bolsas concedidas pelo CNPq, CAPES ou Decanatos da IFES, mediante seleção do desempenho escolar do aluno. São ações regulamentadas pelo Regimento Geral da IFES, somam-se a estas, as atividades acadêmicas cientifico culturais previstas no Art $1^{\circ}$, inciso IV da Resolução CNE/CP 02/2002 (BRASIL, 2002b), que compreendem: participação em congressos, seminários, conferências, entre outros.

A estruturação dos currículos voltados à participação nas mais diversas atividades acadêmicas científico-culturais faz fomentar no egresso uma visão ampla do universo acadêmico e social, preparando-se para ser um profissional aberto a novas tendências regionais e mundiais. Essa é a visão do projeto Tuning, criar uma rede de comunicação de aprendizado, onde comunidades de acadêmicos e estudantes interconectados, debatem, refletem, elaboram e partilham resultados. O projeto Tuning América Latina e o PPC da IFES pesquisada convergem, o que é uma boa conclusão nesse processo de investigação. 


\section{Análise das respostas dos docentes ao ques- tionário}

\subsection{Etapas da pesquisa}

A pesquisa foi idealizada com o objetivo de detectar o nível de disseminação do Projeto Tuning América Latina no meio acadêmico e analisar o conhecimento que os docentes de matemática de uma IFES, escolhida por conveniência, têm acerca das Diretrizes Curriculares Nacionais para o curso de Licenciatura em Matemática.

A pesquisa teve caráter descritivo, pois, de acordo com Gil (2008, p.28), "São incluídas neste grupo as pesquisas que têm por objetivo levantar as opiniões, atitudes e crenças de uma população". A pesquisa verificou, ainda, a relação dos docentes com o Projeto Pedagógico do Curso de Licenciatura em Matemática da instituição, o que agregou ao estudo características de uma pesquisa exploratória. Ainda conforme afirma Gil (2008, p.28): "há pesquisas que, embora definidas como descritivas, a partir de seus objetivos, acabam servindo mais para proporcionar uma nova visão do problema, o que as aproxima das pesquisas exploratórias".

Os dados foram coletados por meio de um questionário com uma exposição prévia contendo as instruções esclarecedoras do propósito de sua aplicação, ressaltando a contribuição extremamente valiosa da participação do docente para a pesquisa. O questionário foi elaborado de maneira clara e objetiva com apenas nove questões, todas rigorosamente necessárias para atender os objetivos da pesquisa.

A pesquisa se delineou por levantamento de campo, buscando obter um grupo significativo de pessoas para que a pesquisa se fizesse o mais fidedigna possível.

\footnotetext{
O pesquisador seleciona os elementos a que tem acesso, admitindo que estes possam, de alguma forma, representar o universo. Aplica-se este tipo de amostragem em estudos exploratórios ou qualitativos, onde não é requerido elevado nível de precisão. (GIL, 2008, p.94)
}

Para obter êxito neste processo, foi necessário perseverança, humildade e paciência, para atingir 20(vinte) professores da área de matemática da IFES pesquisada. A análise das respostas dos questionários foi organizada por meio de recursos manuais, e evidenciou pontos suficientemente curiosos. 


\title{
6.2 Análise e discussão dos resultados
}

Após tabular os dados e elaborar os índices e cálculos estatísticos, optou-se por utilizar recursos gráficos ou apenas os índices percentuais para interpretar e analisar os resultados. Como afirma Gil (2008, p.163),

\begin{abstract}
O tratamento dos dados, a inferência e a interpretação, por fim, objetivam tornar os dados válidos e significativos. Para tanto são utilizados procedimentos estatísticos que possibilitam estabelecer quadros, diagramas e figuras que sintetizam e põem em relevo as informações obtidas. À medida que as informações obtidas são confrontadas com informações já existentes, pode-se chegar a amplas generalizações, o que torna a análise de conteúdo um dos mais importantes instrumentos para a análise das comunicações de massa.
\end{abstract}

A análise dos dados foi feita primeiramente verificando se os objetivos da pesquisa foram atendidos, e os resultados revelaram-se surpreendentes. Ao investigar os dados que atendem ao primeiro objetivo da pesquisa, verificou-se que, do grupo de professores pesquisados, todos disseram não ter conhecimento da existência do projeto Tuning América Latina. Com 100\% dos pesquisados em desconhecimento ao Tuning América Latina, a pesquisa mostrou que a disseminação do projeto encontra-se no nível mais baixo possível, mesmo após 10 anos do seu surgimento, ele ainda é muito pouco conhecido.

Com relação ao segundo objetivo da pesquisa, apenas $25 \%$ dos professores mostraram ter conhecimento do teor das DCN para o curso de Licenciatura em Matemática. No geral, 15\% revelaram total desconhecimento das propostas das DCN, $40 \%$ apontaram conhecimento parcial e os outros $20 \%$ não responderam de forma satisfatória. Isso está evidenciado na Figura 4.

Figura 4 - Conhecimento do teor das DCN para o curso de Licenciatura em Matemática por parte dos docentes da IFES

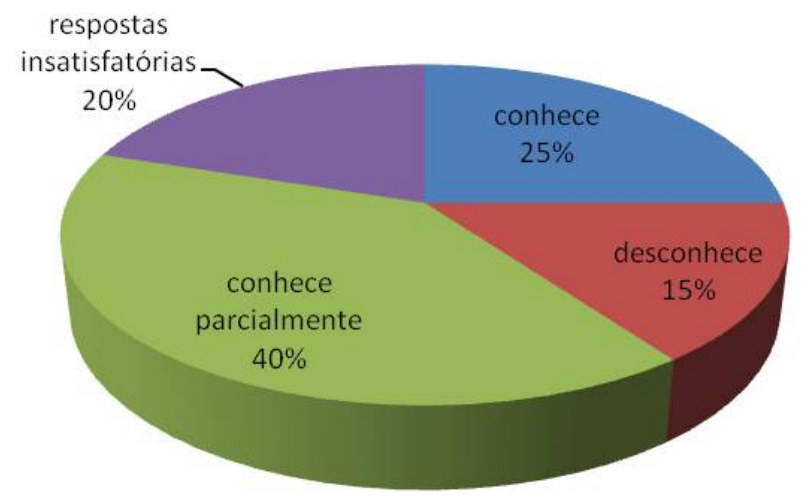

Fonte: Próprio autor, 2015. 
Esse índice revela um grau muito baixo de conhecimento por parte dos docentes de matemática a respeito das DCN e o resultado torna-se ainda menor ao restringir a análise apenas aos professores que ministram aula na licenciatura, já que, surpreendentemente, o percentual reduz de $25 \%$ para pouco mais de $12 \%$. A Figura 5 abaixo traz os valores segundo a atuação docente.

Figura 5 - Conhecimento do teor das DCN para o curso de Licenciatura em Matemática por professores que ministram aulas na Licenciatura em Matemática

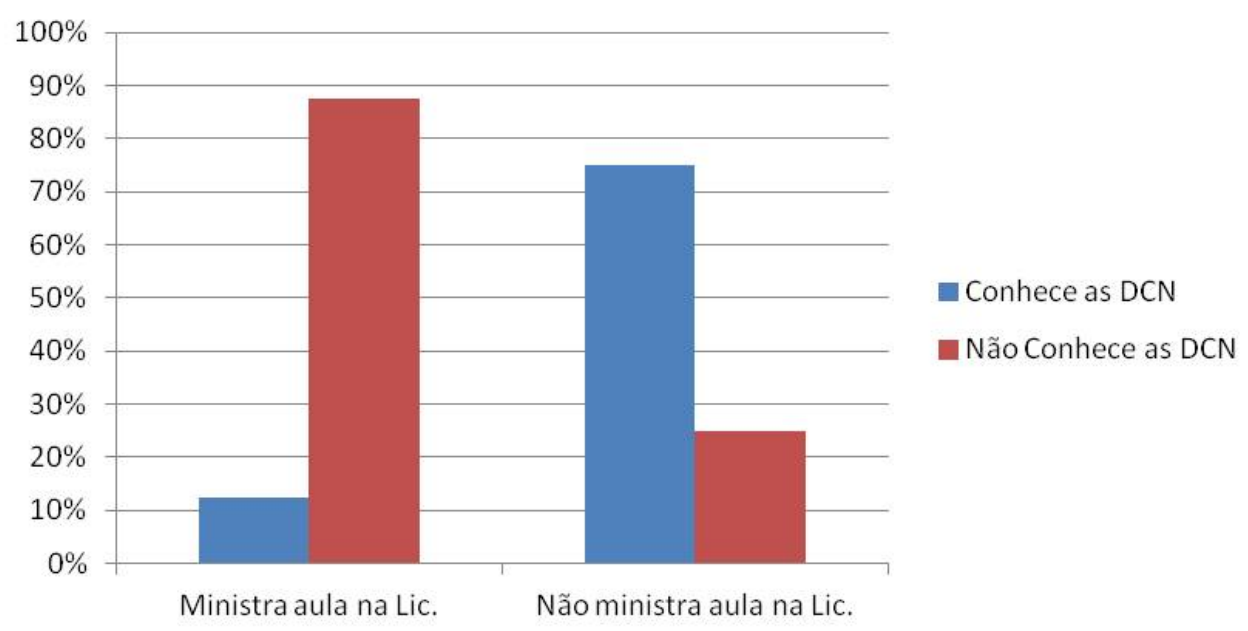

Fonte: Próprio autor, 2015.

O estudo relata um dado extremamente preocupante, pois com um índice tão baixo de informação a respeito das DCN por parte dos docentes atuantes no curso de formação dos futuros professores de matemática, não se pode avaliar de forma efetiva a real implementação das propostas estabelecidas pelas diretrizes. É difícil conceber uma atuação docente descontextualizada, sem considerar o seu papel na constituição dos futuros professores de matemática da educação básica.

Há tempos os programas educacionais mudaram e passaram a dar mais ênfase ao desenvolvimento das capacidades do aluno e suas competências, como também na descrição das funções docente. O art. 13 da Lei de Diretrizes e Bases da Educação Nacional (BRASIL, 1996) afirma que é de responsabilidade docente a participação na elaboração da proposta pedagógica do estabelecimento de ensino, bem como na elaboração e cumprimento do plano de trabalho, segundo essa proposta pedagógica. No entanto, a pesquisa mostrou que existe ainda uma parcela considerável dos professores do curso de licenciatura em matemática estudado que não conhecem a proposta pedagógica do curso que atuam, conforme se infere dos dados a seguir (ver Figura 6). 
Figura 6 - Conhecimento do PPC entre aqueles que atuam na licenciatura

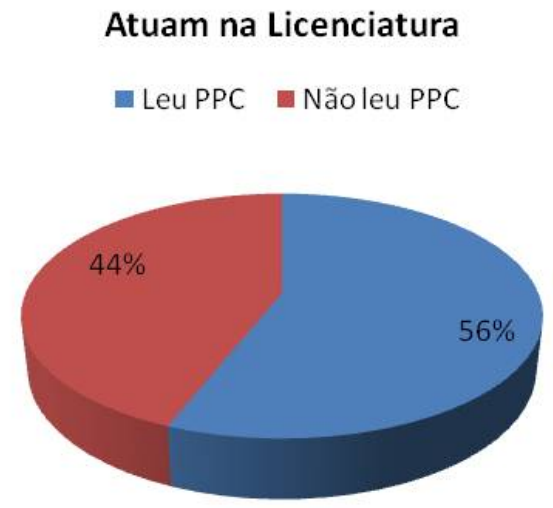

Fonte: Próprio autor, 2015.

Se a análise for feita com relação ao sexo, tem-se uma adesão de leitura maior por parte das mulheres. Entre os que leram o PPC, 56\% são do sexo feminino e, pouco mais de $70 \%$ dos que alegaram não ter lido o PPC, são do sexo masculino. A Figura 7 a seguir evidencia essa informação.

Figura 7 - Conhecimento do PPC entre aqueles que atuam na licenciatura por gênero

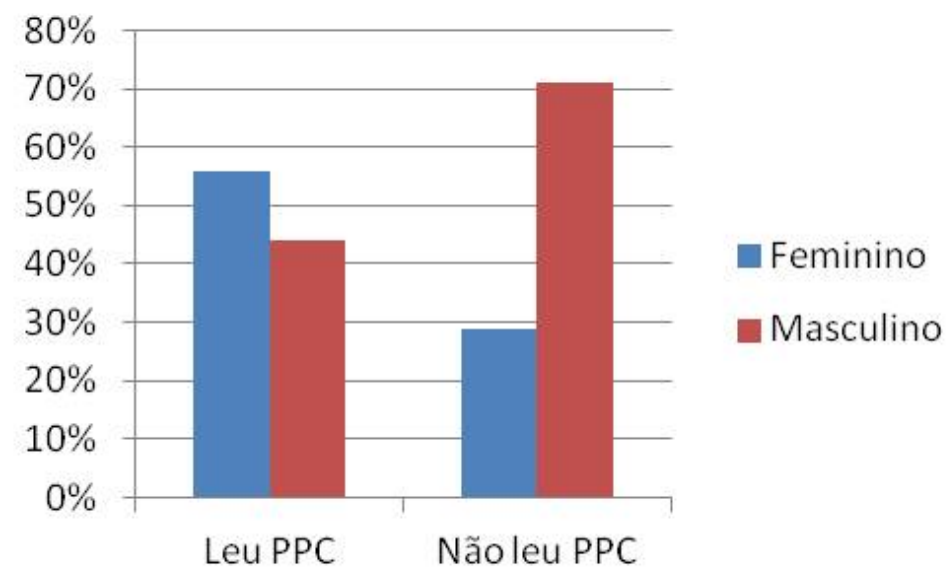

Fonte: Próprio autor, 2015.

Por outro lado, sabe-se que as DCN apontam orientações que devem ser seguidas por todas as instituições para a elaboração do seu PPC, e este, deve ser elaborado coletivamente e ser de fácil acesso a todos. No entanto, os altos percentuais de desconhecimento do PPC de Licenciatura em Matemática indicam a necessidade de um trabalho mais efetivo da coordenação no sentido de envolver a todos do grupo na elaboração e efetiva prática do PPC, começando por conscientizar os docentes mais jovens nas ações pedagógicas que podem desenvolver para colaborar com o crescimento do aluno e da instituição como um todo. Os resultados mostram que entre professores mais jovem $66 \%$ não conhecem 
o PPC do curso que ministram aulas, e quando analisado o tempo de atuação no curso independentemente da idade, continua sendo maior o número dos professores que não tem conhecimento do PPC. A Figura 8 a seguir ilustram, de forma bastante clara, esses os resultados.

Figura 8 - Conhecimento do PPC entre aqueles que atuam na licenciatura segundo o tempo de atuação e idade
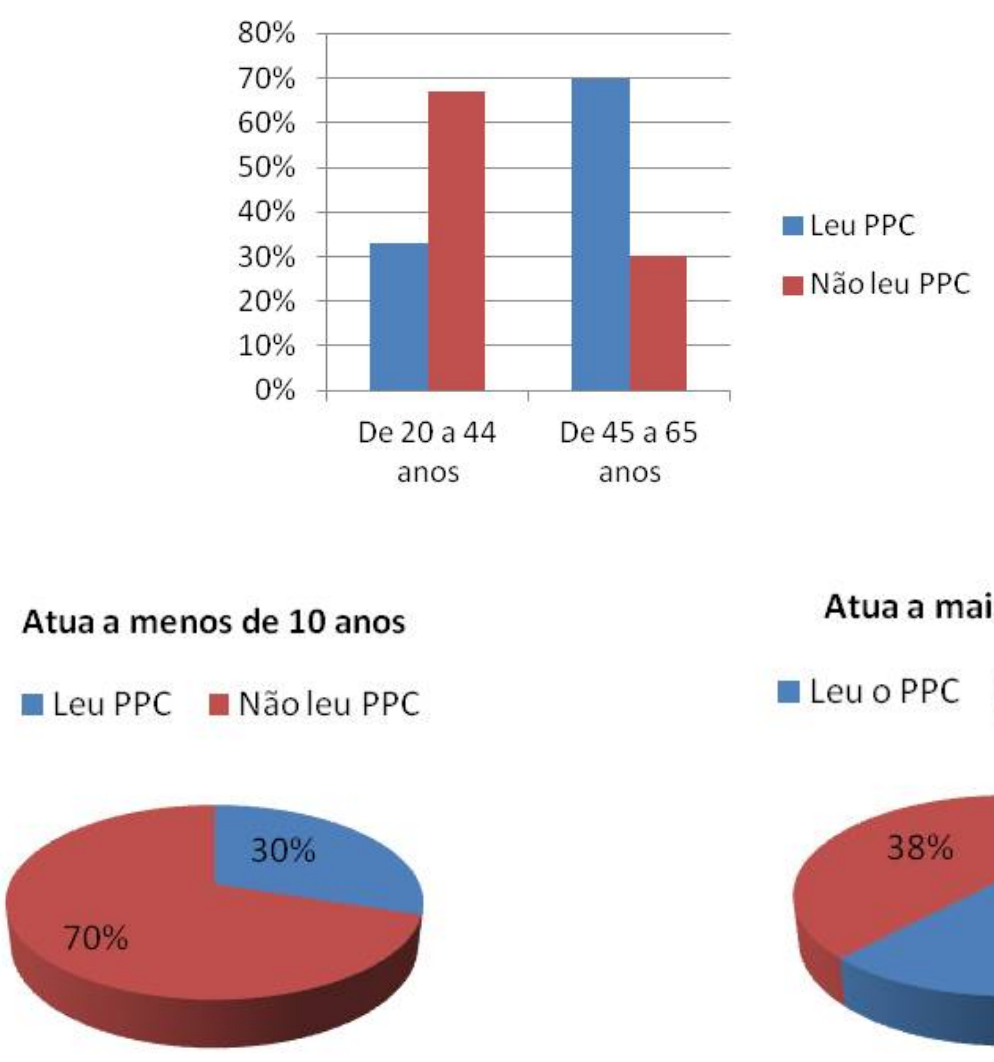

Atua a mais de 20 anos

- Leu oPPC Nãoleu oPPC

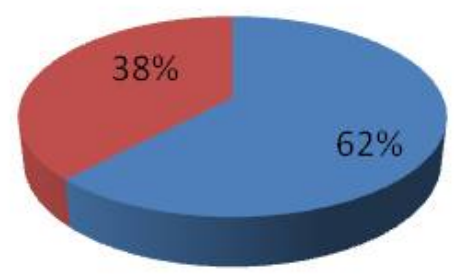

Fonte: Próprio autor, 2015.

É necessária uma política de mudança de hábitos e de conscientização dos professores do real papel que exercem como educador. As DCN para a Licenciatura em Matemática orientam para uma ampla formação profissional, no entanto, a falta de intimidade com essa proposta requer ações pedagógicas voltadas para a reestruturação da prática docente. O professor precisa tomar ciência da importância de o aluno desenvolver as competências que contribuam efetivamente para o alcance do perfil profissional de formação desejado, e descobrir como as disciplinas que ministra contribuem para tornar esse aluno um profissional completo e capaz de realizar suas tarefas de forma competente, para tornar a sociedade melhor para essa geração de jovens que está em idade escolar. 


\section{Considerações finais}

O objetivo deste trabalho foi analisar a relação do Projeto Tuning América Latina na área de matemática com as Diretrizes Curriculares Nacionais para a Licenciatura em Matemática. Trilhando os mesmos caminhos das DCN, o projeto visa construir um sistema educacional mais sensível aos novos desafios, no qual a qualidade do processo de aprendizagem é objetivo principal.

O primeiro passo do estudo foi descrever e compreender a estrutura organizacional, os objetivos, as linhas de trabalho, as propostas educacionais do Projeto Tuning América Latina, as relações e perspectivas do Projeto Tuning na área da matemática, destacando-se aquelas consideradas relevantes na construção e desenvolvimento da análise comparativa entre o projeto e as DCN. Um conjunto de propostas foi sinalizado e, juntas, essas propostas sugerem que as universidades possam harmonizar seus planos de estudos. No intuito de organizar a discussão na área da matemática, foram destacadas quatro linhas de abordagem: competências gerais, competências específicas, CLAR e enfoques da aprendizagem.

Para que o trabalho comparativo fluísse mais facilmente, as competências gerais e específicas das DCN e do projeto Tuning América Latina foram comparadas em tabelas com notações que as identificassem. Analisadas uma a uma, concluiu-se que há uma relação direta de convergência entre as DCN e projeto Tuning América Latina, na área da matemática.

Buscou-se também verificar a proximidade das propostas do Projeto Tuning América Latina na área de matemática com o Projeto Pedagógico do curso de Licenciatura em Matemática de uma instituição federal de ensino superior (IFES), o qual passou por reformulação recente buscando-se adaptar às novas normas educacionais. Identificou-se nos próprios relatos do PPC que a sua reformulação foi realizada procurando-se adequar as inovações na formação dos futuros professores, com vistas ao desenvolvimento do ambiente de aprendizagem adequado para o crescimento da prática educativa, incentivando a aplicação de metodologia experimental focada nas experiências desenvolvidas pelos alunos e colocando maior ênfase na resolução de problemas como ferramenta importante na formação do licenciado. Esse fato foi um entre muitos outros direcionados na linha de abordagem do projeto Tuning.

A responsabilidade social e o compromisso com a cidadania foi uma das semelhanças destacadas neste trabalho e concluiu-se que, tanto nas DCN como no projeto Tuning América Latina, o seu desenvolvimento deve ocorrer de forma transversal no currículo. Os princípios éticos são cultivados no trabalho diário das comunidades e se faz necessário estimular mais o desenvolvimento dessas atitudes, uma vez que, em algumas instituições, 
o seu desenvolvimento e fortalecimento são insuficientes ou até inexistentes. No PPC analisado, essa era a primeira característica destacada no perfil do egresso.

Não somente o perfil, mas as competências gerais e específicas de ambos se fundem. No geral, as DCN são mais sucintas, enquanto o projeto Tuning é mais descritivo e detalhado já que se trata de uma metodologia. Por exemplo, este elenca 50 competências ao passo que as DCN descrevem apenas 17. Constatou-se que, em média, duas a três competências descritas no Tuning América Latina convergiam em uma das DCN.

Por ser um projeto internacional focado na formação por competências, sem perder a identidade cultural regional e a diversidade de cada país participante, o projeto Tuning América Latina valoriza as competências comunicacionais e as de dimensão relacional, reconhecimento dado também pelas DCN, que sinalizam que os PPC devem ser elaborados de maneira a desenvolver as competências direcionadas ao desenvolvimento adequado no que diz respeito à comunicação com outras áreas profissionais, bem como promover e reforçar o trabalho em equipes interdisciplinares. No entanto, o que se percebeu no PPC pesquisado foi uma maior abordagem ao trabalho individual em detrimento ao trabalho em equipe.

Apenas três anos separaram as duas propostas de melhoria para a educação superior. De um lado as DCN, como um documento de âmbito nacional homologado em 2001, do outro, o projeto Tuning América Latina, de âmbito internacional e criado em 2004. Um não foi pensado, nem tampouco fundado a partir do outro, mas a percepção de ambos é a mesma: servir de direcionamento para a melhoria e transformação da formação do futuro matemático, visando ao desenvolvimento da qualidade, eficiência e transparência dos programas de ensino superior.

Paralelamente, foi investigado, por meio de uma pesquisa com um grupo de professores que atuam no curso de Matemática de uma IFES, o grau de conhecimento que esses docentes têm acerca das DCN da área da matemática, ao mesmo tempo em que se buscou detectar o nível de disseminação do Projeto Tuning América Latina no meio acadêmico. Esse estudo serviu para verificar que 100\% dos professores pesquisados não conhecem e nem ouviram falar do Projeto Tuning. E, o mais surpreendente da pesquisa, foi detectar de $44 \%$ dos professores que atuam diretamente no curso de Licenciatura em Matemática nunca leram o PPC do curso que ministram aulas e, mesmo os que disseram conhecer o PPC, não responderam corretamente as afirmações relacionadas às DCN, apenas $25 \%$ têm conhecimento do conteúdo trazido pelas DCN.

O estudo comparativo serviu para verificar a relação de proximidade entre as DCN e o projeto Tuning América Latina. Hoje, a sociedade está cada vez mais dinâmica e o processo de educação deve evoluir no mesmo ritmo; no entanto, quando se fala em um projeto que tem como proposta a reestruturação curricular embasada em competências, com foco no aluno, a comunidade acadêmica a recebe com resistência embora não se dê 
conta que o documento que rege toda a estrutura pedagógica de planejamento do processo de educação superior esteja em consonância com este projeto.

Como bem sintetizou uma das professoras coordenadoras do projeto Tuning, entrevistada na pesquisa:

A excelência da educação superior só pode ser conseguida por meio do estudante. $\mathrm{O}$ estudante tem que ser motivado, ele tem que entender que é o principal sujeito ativo do processo de educação. Ele é o sujeito da transformação do processo, todo o processo é dirigido a ele. O processo de educação só acontece quando os docentes são capazes de compreender que esse é um processo de confiança e a confiança do estudante só se estabelece quando os estudantes entendem que os docentes são generosos na sua possibilidade de mudança. (FELIX, 2015)

No mundo globalizado em vivemos, é preciso planejar a educação superior com o desafio de continuar elaborando as estruturas educativas para que sejam mais dinâmicas e criativas, favorecer a mobilidade estudantil e criar pontes necessárias com todas as regiões do mundo.

A intenção deste estudo foi mostrar que a proposta do projeto internacional Tuning América Latina, pouco conhecido, não está em discordância com a legislação brasileira, está mais próximo da nossa estrutura educacional do que se imagina. A finalidade é provocar o debate entre estudantes, acadêmicos e autoridades da importância da convergência curricular, cada vez mais necessária para o reconhecimento das competências dos futuros profissionais da matemática. Com isso, fazer com que as portas da educação superior se abram ao debate de novas mudanças.

Nas palavras da coordenadora entrevistada, o Tuning América Latina é

uma oportunidade de olhar para a educação superior a partir de uma perspectiva muito mais criativa, transformadora, renovadora, abrindo mão de todas as certezas que tinha sobre como deveria ser buscada a excelência da educação superior. A excelência da educação superior só pode ser conseguida por meio do estudante.

O estudo mostrou que uma parcela significativa dos docentes desconhece o próprio projeto pedagógico do curso em que atuam. A análise dos questionários revelou que $44 \%$ dos docentes nunca leram o PPC do curso que ministram aula e, mesmo aqueles que atuam há mais de vinte anos no curso de matemática, $38 \%$ revelaram que em tempo algum tomaram conhecimento do projeto pedagógico. Entre os que têm menos de dez anos trabalhando no curso, apenas 30\% relataram já ter lido o PPC da Licenciatura em Matemática, o que aponta para uma urgente ruptura dessa tradição por parte dos docentes mais jovens.

Esses dados espantosos sinalizam para a necessidade de um trabalho mais efetivo da coordenação no sentido de disseminar os princípios torneadores do PPC, de modo a 
que cada docente descubra como as disciplinas que ministram se articulam no currículo e quais ações pedagógicas precisam desenvolver para contribuir com o alcance do perfil profissional de formação desejado.

Possivelmente haja a vontade por parte de alguns docentes em justificar o seu desinteresse em conhecer o PPC pela dificuldade de acesso e por se tratar de um documento que evidenciou uma difícil leitura, devido à forma como foi estruturado e organizado. No entanto, é injustificável e não se pode conceber uma atuação docente descontextualizada, que não considere o seu papel na formação dos estudantes, futuros professores de matemática da educação básica.

Isso abre a possibilidade para continuidade da pesquisa no que diz respeito à real implementação dos princípios/pressupostos estabelecidos no PPC. Se uma quantidade significativa dos docentes desconhece a proposta do projeto pedagógico do curso em que atuam, como garantir sua efetiva implementação, já que isso somente ocorre por intermédio de um trabalho coletivo e articulado? E do ponto de vista discente, como o aluno percebe a formação ao longo do curso? De fato os objetivos estabelecidos estão sendo atingidos? A dicotomia teoria versus prática precisa ser melhor estudada nesse caso específico.

Fica também evidente que mais estudos são necessários para avaliar as propostas do projeto Tuning América Latina e o impacto que elas causarão, uma vez que o próprio papel da universidade é posto em cheque, como local de produção do conhecimento, da pesquisa e da formação social, para corresponder não somente às expectativas e necessidades do mercado de trabalho, mas à formação de profissionais comprometidos com o bem-estar comum, capazes de atuar em equipes multidisciplinares, autônomos, pró-ativos, criativos, comprometidos com as grandes questões globais e que, sobretudo, sejam éticos em suas ações. 


\section{Referências}

ACADEMIA BRASILEIRA DE LETRAS. Dicionário Escolar da língua Portuguesa. 2. ed. São Paulo: Companhia Editora Nacional, 2008. Citado na página 49.

ACREDITACIÓN, A. N. D. E. D. L. C. Y. Glosario internacional RIACES de Evaluacion de la Calidad y Acreditacióm. Madrid: Omán, 2004. Citado na página 36.

BARDIN, L. Análise de conteúdo. São Paulo: Edições 70, 2011. Citado 4 vezes nas páginas $14,17,54$ e 62 .

BENEITONE, P. et al. Reflexões e perspectivas do Ensino Superior na América Latina: Relatório Final - Projeto Tuning América Latina 2004-2007. Espanha: Universidade de Deusto, 2007. Citado 15 vezes nas páginas 13, 19, 21, 22, 24, 26, 27, 28, 29, 32, 36, 37, 38, 42 e 43.

BENEITONE, P.; GONZáLEZ, J.; WAGENAAR, R. Meta - perfis e perfis: Uma nova aproximação para os diplomas na América Latina. Espanha: Universidade de Deusto, 2014. Citado na página 44.

BRASIL. Lei de diretrizes e bases da educação nacional, lei nº 9.394, de 20 de dezembro de 1996. Coletânea de Legislação: edição federal, Brasília, 1996. Citado 4 vezes nas páginas $17,59,66$ e 72 .

BRASIL. Parecer CNE/CES 1.302, de 2001.Diretrizes Curriculares Nacionais para os Cursos de Matemática, Bacharelado e Licenciatura. Brasília: [s.n.], 2001. Disponível em: <http://portal.mec.gov.br/cne/arquivos/pdf/CES13022.pdf>. Acesso em: 20 jan. 2015. Citado 4 vezes nas páginas 17, 49, 52 e 55 .

BRASIL. Parecer CNE/CP 09, de 2001. Diretrizes Curriculares Nacionais para a Formação de Professores da Educação Básica, em nível superior, curso de licenciatura, de graduação plena. Brasília: [s.n.], 2001. Disponível em: <http://portal.mec.gov.br/cne/arquivos/pdf/ 009.pdf > . Acesso em: 20 jan. 2015. Citado 2 vezes nas páginas 17 e 64 .

BRASIL. Resolução CNE/CP 1, de 2002. Brasília: [s.n.], 2002. Disponível em: <http: //portal.mec.gov.br/cne/arquivos/pdf/rcp01_02.pdf $>$. Acesso em: 21 jan. 2015. Citado na página 17.

BRASIL. Resolução CNE/CP 2, de 2002. Brasília: [s.n.], 2002. Disponível em: <http: //portal.mec.gov.br/cne/arquivos/pdf/CP022002.pdf>. Acesso em: 21 jan. 2015. Citado 5 vezes nas páginas 17, 57, 59, 65 e 69 .

BRASIL. Resolução CNE/CES 3, de 2003. Brasília: [s.n.], 2003. Disponível em: <http: //portal.mec.gov.br/cne/arquivos/pdf/ces032003.pdf $>$. Acesso em: 20 jan. 2015. Citado 3 vezes nas páginas 17,57 e 60 .

BRASIL. Lei $n^{o}$ 13005, de 25 de junho de 2014. Lei do Plano Nacional de Educação. Brasília: [s.n.], 2014. Disponível em: <http://www.fnde.gov.br/fnde/legislacao/leis/>. Acesso em: 25 maio 2015. Citado na página 14. 
CLAR. CLAR: Crédito Latinoamericano de Referência. Espanha: Universidade de Deusto, 2013. Citado 3 vezes nas páginas 32, 33 e 35.

COELHO, H. Tecnologias de informação. Lisboa: D. Quixote, 1986. Citado na página 25.

FELIX, L. P. M. Entrevista I. [mar. 2015]. Brasília: Entrevistador: Rosana de Andrade. 1 audio (32 min), 2015. Citado na página 77.

GIL, A. C. Métodos e técnicas de pesquisa social. 6. ed. São Paulo: Atlas, 2008. Citado 5 vezes nas páginas 14, 17, 18, 70 e 71 .

LUDKE, M.; ANDRé, M. E. D. A. Pesquisa em educação: abordagens qualitativas. São Paulo: EPU, 1986. Citado na página 14.

MAY, T. Pesquisa social: questões, métodos e processos. 3. ed. Porto Alegre: Artmed, 2004. Citado na página 18.

PANIAGUA, M. J. A. et al. Ensino Superior na América Latina: reflexões e perspectivas sobre Matemática. Espanha: Universidade de Deusto, 2014. Citado 6 vezes nas páginas $28,41,44,45,47$ e 48.

RABELO, M. L. Avaliação Educacional: fundamentos, metodologias e aplicações no contexto brasileiro. Rio de Janeiro: SBM, 2013. Citado na página 63.

RICHARDSOn, R. J. Pesquisa Social: métodos e técnicas. São Paulo: Atlas, 1999. Citado na página 18.

VAN DAMME, D. Quality issues in the internationalization of higher education. [S.1.]: Higher Education, nº 41, p. 415-441., 2001. Citado na página 13.

VEIGA, I. P. A. Projeto Político pedagógico da escola: Uma construção possível. 24. ed. São Paulo: Papirus editora, 2008. Citado na página 59.

VILLA, A. et al. Um modelo de avaliação de Inovação Social Universitária Responsável (ISUR). Espanha: Universidade de Deusto, 2014. Citado 3 vezes nas páginas 20, 21 e 24. 
Parte I

Apêndices 


\section{QUESTIONÁRIO}

Prezado(a) Professor(a)

Este questionário foi idealizado com o objetivo de detectar o nível de disseminação do Projeto Tuning América Latina no meio acadêmico e analisar o nível de conhecimento que os docentes têm a cerca das Diretrizes Curriculares Nacionais para o curso de Licenciatura em Matemática. Sua contribuição será extremamente valiosa para a pesquisa que estamos desenvolvendo como parte do trabalho de conclusão de curso do Mestrado Profissional em Matemática - PROFMAT. Todas as informações serão divulgadas de forma impessoal, em forma de análises estatísticas.

Desde já agradeço sua colaboração.

1) Idade: anos.

2) Sexo: ( ) F ( ) $\mathrm{M}$

3) Tempo de atuação na educação superior: anos.

4) Tempo que atua no Departamento de Matemática: anos.

5) Ministra aula para estudantes da Licenciatura em Matemática?

( ) Sim ( ) Não

6) Conhece o Projeto Tuning América Latina ou já ouviu falar sobre esse Projeto?

( ) $\operatorname{Sim}$ ( ) Não

7) Você já leu o Projeto Pedagógico do Curso de Licenciatura em Matemática de sua instituição?

( ) Sim ( ) Não

Em caso afirmativo, o que você acha que ele tem como ponto forte?

8) Em que aspecto(s) a(s) disciplina(s) que você ministra contribui(em) para a formação do licenciado em matemática?

9) Qual afirmação abaixo você escolheria como verdadeira em relação às Diretrizes Curriculares Nacionais para os cursos de Licenciatura em Matemática?

( ) As DCN estabelecem uma lista de conteúdos que devem ser ministrados a cada ano para os estudantes da licenciatura.

( ) As DCN descrevem o perfil profissional de formação, as competências e as habilidades que devem ser desenvolvidas pelos estudantes do curso.

( ) As DCN determinam o número máximo de horas que devem integrar a proposta pedagógica do curso e a quantidade de créditos que os estudantes devem fazer por semestre.

( ) As DCN orientam as instituições de ensino superior no que diz respeito à forma em que deve ser estruturada o projeto pedagógico do curso.

( ) As DCN estabelecem uma lista de disciplinas obrigatórias e sugerem algumas disciplinas optativas que devem integrar o currículo do curso. 


\section{ROTEIRO PARA A ENTREVISTA \\ COM UMA DAS COORDENADORAS DO PROJETO TUNING AMÉRICA LATINA PROFESSORA LOUSSIA PENHA MUSSE FELIX}

1) Nos mesmos moldes do Tuning Europa, o Projeto Tuning América Latina também é planejado por fases e, segundo o material bibliográfico a primeira fase do Tuning América Latina foi de 2004 a 2007 e a próxima de 2011 a 2013. O que ocorreu nesse período de dois anos que não foi identificado como uma fase do projeto? Qual foi o objetivo desse intervalo? E hoje em que fase se encontra o Tuning América Latina?

2) No site oficial do Projeto aparece, por exemplo, $4^{\mathrm{a}}$ Reunião Geral do Tuning América Latina Fase I e $2^{\text {a }}$ Reunião Geral Tuning América Latina Fase II. Como funciona essa dinâmica das Reuniões Gerais?

3) Desde a implantação do Projeto Tuning aqui na América Latina tem-se a participação de 18 países elegíveis e mais a República Dominicana. A senhora sabe se, durante esses 10 anos de projeto houve alguma alteração desses participantes?

4) O Projeto Tuning América latina iniciou seus trabalhos com 62 universidades latinoamericanas, passando logo em seguida para 182 universidades, atuando em 4 áreas temáticas. A senhora sabe, quantas são as universidades latino-americanas que participam do projeto?

5) Pelo que eu li, as áreas temáticas também cresceram junto com o projeto. Inicialmente, eram quatro, logo em seguida passaram a ser 12 e hoje quantas são? Quais foram as últimas a serem agregadas? Como funciona essa inserção no Projeto?

6) Qual é a principal função do Comitê de Gestão? Quem o compõe?

7) Todo país possui um Centro Nacional Tuning. Onde funcional o CNT do Brasil?

8) Como funciona a dinâmica de ciclos do Projeto Tuning?

9) O que significa para a senhora, em termos de experiência profissional docente, a participação como representante da UnB nesse projeto?

10) De modo geral, os professores de sua unidade acadêmica conhecem a proposta do projeto na sua área? Em sua opinião, o que pode ser feito para dar maior visibilidade para o projeto?

11) Os trabalhos oriundos do projeto influenciam em alguma medida o projeto pedagógico do curso em que a senhora atua na Universidade?

12) Quais os pontos positivos do projeto que a senhora poderia citar?

13) Há pontos negativos? Quais?

14) Há algo que a senhora gostaria de acrescentar?

15) O que a senhora acha que eu não posso deixar de mencionar em meu trabalho a respeito do projeto? 


\section{TERMO DE CONSENTIMENTO LIVRE E ESCLARECIDO}

Eu, XXXXXXXXXXXXXXXXX, chefe do departamento de matemática da

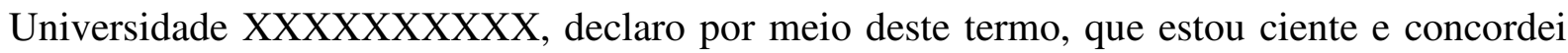
com a pesquisa intitulada "A convergência do Projeto Tuning América Latina com as Diretrizes Curriculares Nacionais da Licenciatura em Matemática", desenvolvida por Rosana de Andrade Araújo, aluna de mestrado do departamento de matemática da Universidade de Brasília, sob a supervisão e orientação do Prof. Dr. Mauro Rabelo, que será realizada com os docentes do departamento.

Afirmo que a participação dos docentes do departamento de matemática se dará, sem receber qualquer incentivo financeiro ou ter qualquer ônus e com a finalidade exclusiva de colaborar para o sucesso da pesquisa e, caso algum professor decida não participar ou quiser desistir de continuar em qualquer momento, têm absoluta liberdade de fazê-lo. Fui informado dos objetivos estritamente acadêmicos do estudo, que, em linhas gerais é: Analisar a relação do Projeto Tuning América Latina na área da matemática com as Diretrizes Curriculares Nacionais do curso de Licenciatura em matemática. A colaboração dos professores se fará de forma anônima, por meio de um questionário com perguntas semiestruturadas.

O acesso e a análise dos dados coletados se farão apenas pela pesquisadora e/ou seu orientador. Atesto recebimento de uma cópia assinada deste Termo de Consentimento Livre e Esclarecido, conforme recomendações da Comissão Nacional de Ética em Pesquisa (CONEP).

Quaisquer dúvidas relativas à pesquisa poderão ser esclarecidas pela pesquisadora Rosana de Andrade Araújo por telefone XXXXXXX ou por e-mail XXXXXX@ hotmail.com.

Brasília, de de 2015.

Pesquisador: Rosana de Andrade Araújo

Orientador: Prof. Dr. Mauro Rabelo

Chefe do Departamento de Matemática da Universidade XXXXXXX 
Parte II

Anexos 


\section{ANEXO I - Lista das Universidades participantes do Projeto Tuning América Latina}

(CLAR,2013)

\section{Argentina:}

Universidad de Buenos Aires

Universidad Nacional de Córdoba

Universidad Nacional de La Plata

Universidad Nacional de Rosario

Universidad Nacional de Cuyo

Universidad Tecnológica Nacional

Universidad Nacional del litoral

Universidad Nacional del Sur

Universidad Nacional de San Juan

Universidad Nacional de San Luis

Universidad Nacional del Nordeste

Universidad Nacional de Río Cuarto

Universidad Nacional de Jujuy

Universidad Nacional de Lanús

Universidad Nacional del Centro de la Provincia de Buenos Aires

Universidad Nacional del Nordeste de la Provincia de Buenos Aires

Universidad Nacional de Tres de Febrero

\section{Bolívia:}

Universidad Mayor de San Andrés

Universidad Mayor de San Simón

Universidad Católica Boliviana «San Pablo»

Universidad Autónoma Tomás Frías

Universidad Privada Santa Cruz de la Sierra

Universidad Privada del Valle

Universidad Evangélica Boliviana

Universidad Privada Boliviana

Universidad Núr.

\section{Brasil:}

Universidade de Brasília

Universidade Federal de Santa Catarina

Universidade Federal de Uberlândia

Universidade de Caxias do Sul-UCS

Universidade Federal de Ouro Preto

Universidade Federal Ceará

Universidade Federal do Pará

Universidade do Estado do Rio de Janeiro

Universidade Presbiteriana Mackenzie -São Paulo.

Chile:

Universidad de Chile

Universidad de la Frontera

Universidad de Santiago de Chile 
Universidad de Bio Bio

Universidad de Tarapacá, Universidad de Concepción

Pontificia Universidad Católica de Chile

Universidad Andrés Bello

Universidad Austral de Chile

Universidad Católica de Temuco

Universidad Católica del Norte

Universidad Diego Portales Fundación

Universidad Alberto Hurtado

Universidad Técnica Federico Santa María

Universidad Católica Silva Henríquez

\section{Colômbia:}

Universidad Nacional de Colombia

Universidad de Antioquía

Universidad de Caldas

Universidad Industrial de Santander

Universidad del Valle

Universidad Tecnológica de Pereira

Universidad Pedagógica y Tecnológica de Colombia

Pontificia Universidad Javeriana

Fundación Universidad del Norte

Universidad EAFIT

Universidad Externado de Colombia

Universidad Colegio Mayor de Nuestra Señora del Rosario

Universidad de la Sabana

Universidad Pontificia Bolivariana

\section{Costa Rica:}

Universidad de Costa Rica

Instituto Tecnológico de Costa Rica

Universidad Estatal a Distancia

Universidad Nacional

\section{Cuba:}

Universidad de La Habana

Instituto Superior Politécnico

Universidad Central de Las Villas

Instituto Superior Minero Metalúrgico

\section{Equador:}

Universidad Central del Ecuador

Escuela Superior Politécnica del Litoral (ESPOL)

Escuela Superior Politécnica de Chimborazo

Escuela Politécnica del Ejército

Universidad de Cuenca

Universidad de Guayaquil

Universidad Nacional de Loja

Universidad del Azuay 
Universidad Laica Eloy Alfaro de Manabí

Universidad de las Américas

Universidad Tecnológica Equinoccial

Pontificia Universidad Católica del Ecuador

\section{El Salvador:}

Universidad de El Salvador

Universidad Dr. José Matías Delgado

Universidad Centroamericana «José Simeón Cañas»

Universidad Católica de El Salvador

Universidad Salvadoreña Alberto Masferrer

\section{Guatemala:}

Universidad de San Carlos de Guatemala

Universidad Rafael Landívar

Universidad del Valle de Guatemala

\section{Honduras:}

Universidad Nacional Autónoma de Honduras

Universidad Pedagógica Nacional Francisco Morazán.

\section{México:}

Universidad Autónoma Metropolitana

Benemérita Universidad Autónoma de Puebla

Universidad Autónoma de Chiapas

Universidad de Colima

Universidad de Guadalajara

Universidad de Guanajuato

Universidad de Querétaro

Universidad de Sonora

Universidad Autónoma de Nuevo Leó

Universidad Autónoma de Yucatán

Universidad Autónoma del Estado de Hidalgo

Instituto Tecnológico y de Estudios Superiores de Monterrey

\section{Nicarágua:}

Universidad Nacional Autónoma de Nicaragua-Managua

Universidad Nacional Autónoma de Nicaragua-León

Universidad Nacional de Ingeniería

Universidad de las regiones Autónomas de la Costa Caribe

Universidad Centroamericana.

\section{Panamá:}

Universidad de Panamá

Universidad Latinoamericana de Comercio Exterior (ULACEX)

Universidad Latinoamericana de Ciencia y Tecnología

Universidad Latina de Panamá

\section{Paraguai:}


Universidad Nacional de Asunción

Universidad Nacional de Concepción

Universidad Autónoma de Asunción

Universidad Católica Nuestra Señora de la Asunción del Ministerio de Educación y Cultura.

\section{Peru:}

Universidad Nacional Mayor de San Marcos (UNMSM)

Universidad Nacional de San Agustín de Arequipa

Universidad de Piura

Universidad Nacional Agraria La Molina

Universidad Nacional de Ingeniería

Universidad Nacional Federico Villarreal

Universidad Peruana Cayetano Heredia

Universidad del Pacífico

Universidad Peruana Unión

Universidad Ricardo Palma

Pontificia Universidad Católica del Perú

\section{Uruguai:}

Universidad de La República

Universidad Católica del Uruguay «Dámaso Antonio Larrañaga»

\section{Venezuela:}

Universidad Central de Venezuela

Universidad de Carabobo

Universidad Nacional Experimental de los Llanos Centrales Ró- mulo

Universidad de Oriente

Universidad Experimental Simón Bolívar

Universidad Nacional Experimental del Táchira (UNET)

Universidad Centroccidental «Lisandro Alvarado»

Universidad Católica Andrés Bell

Universidad de los Andes 


\section{ANEXO II - Diretrizes Curriculares Nacionais}

\section{MINISTÉRIO DA EDUCAÇÃO CONSELHO NACIONAL DE EDUCAÇÃO}

\begin{tabular}{|c|c|c|c|}
\hline \multicolumn{3}{|c|}{$\begin{array}{l}\text { INTERESSADO: Conselho Nacional de Educação / Câmara de Educação } \\
\text { Superior }\end{array}$} & UF: DF \\
\hline \multicolumn{4}{|c|}{$\begin{array}{l}\text { ASSUNTO: Diretrizes Curriculares Nacionais para os Cursos de Matemática, Bacharelado e } \\
\text { Licenciatura }\end{array}$} \\
\hline \multicolumn{4}{|c|}{$\begin{array}{l}\text { RELATOR(A): Francisco César de Sá Barreto (Relator), Carlos Alberto Serpa de Oliveira, } \\
\text { Roberto Claudio Frota Bezerra }\end{array}$} \\
\hline \multicolumn{4}{|c|}{ PROCESSO(S) N. ${ }^{\circ}(\mathbf{S}): 23001.000322 / 2001-33$} \\
\hline $\begin{array}{l}\text { PARECER N. }{ }^{\circ}: \\
\text { CNE/CES } 1.302 / 2001\end{array}$ & $\begin{array}{l}\text { COLEGIADO: } \\
\text { CES }\end{array}$ & $\begin{array}{l}\text { APRC } \\
06 / 11 /\end{array}$ & ADO EM: \\
\hline
\end{tabular}

\section{I - RELATÓRIO}

Os cursos de Bacharelado em Matemática existem para preparar profissionais para a carreira de ensino superior e pesquisa, enquanto os cursos de Licenciatura em Matemática têm como objetivo principal a formação de professores para a educação básica.

As aplicações da Matemática têm se expandido nas décadas mais recentes. A Matemática tem uma longa história de intercâmbio com a Física e as Engenharias e, mais recentemente, com as Ciências Econômicas, Biológicas, Humanas e Sociais.

As habilidades e competências adquiridas ao longo da formação do matemático tais como o raciocínio lógico, a postura crítica e a capacidade de resolver problemas, fazem do mesmo um profissional capaz de ocupar posições no mercado de trabalho também fora do ambiente acadêmico, em áreas em que o raciocínio abstrato é uma ferramenta indispensável.

Consequentemente os estudantes podem estar interessados em se graduar em Matemática por diversas razões e os programas de graduação devem ser bastante flexíveis para acomodar esse largo campo de interesses.

Assim essas diretrizes têm como objetivos:

- servir como orientação para melhorias e transformações na formação do Bacharel e do Licenciado em Matemática;

- assegurar que os egressos dos cursos credenciados de Bacharelado e Licenciatura em Matemática tenham sido adequadamente preparados para uma carreira na qual a Matemática seja utilizada de modo essencial, assim como para um processo contínuo de aprendizagem.

\section{II - VOTO DO(A) RELATOR(A)}

Diante do exposto e com base nas discussões e sistematização das sugestões apresentadas pelos diversos órgãos, entidades e Instituições à SESu/MEC e acolhida por este Conselho, voto favoravelmente à aprovação das Diretrizes Curriculares para os cursos de Matemática, Bacharelado, e do projeto de resolução, na forma ora apresentada.

Brasília(DF), 06 de novembro de 2001. 
Conselheiro(a) Francisco César de Sá Barreto - Relator(a)

Conselheiro(a) Carlos Alberto Serpa de Oliveira

Conselheiro(a) Roberto Claudio Frota Bezerra

\section{III - DECISÃO DA CÂMARA}

A Câmara de Educação Superior aprova por unanimidade o voto do(a) Relator(a).

Sala das Sessões, em 06 de novembro de 2001.

Conselheiro Arthur Roquete de Macedo - Presidente

Conselheiro José Carlos Almeida da Silva - Vice-Presidente 


\section{DIRETRIZES CURRICULARES PARA CURSOS DE MATEMÁTICA}

\section{Perfil dos Formandos}

Um curso de Bacharelado em Matemática deve ter um programa flexível de forma a qualificar os seus graduados para a Pós-graduação visando a pesquisa e o ensino superior, ou para oportunidades de trabalho fora do ambiente acadêmico.

Dentro dessas perspectivas, os programas de Bacharelado em Matemática devem permitir diferentes formações para os seus graduados, quer visando o profissional que deseja seguir uma carreira acadêmica, como aquele que se encaminhará para o mercado de trabalho não acadêmico e que necessita além de uma sólida base de conteúdos matemáticos, de uma formação mais flexível contemplando áreas de aplicação.

Nesse contexto um Curso de Bacharelado deve garantir que seus egressos tenham:

- uma sólida formação de conteúdos de Matemática

- uma formação que lhes prepare para enfrentar os desafios das rápidas transformações da sociedade, do mercado de trabalho e das condições de exercício profissional.

Por outro lado, desejam-se as seguintes características para o Licenciado em Matemática:

- visão de seu papel social de educador e capacidade de se inserir em diversas realidades com sensibilidade para interpretar as ações dos educandos

- visão da contribuição que a aprendizagem da Matemática pode oferecer à formação dos indivíduos para o exercício de sua cidadania

- visão de que o conhecimento matemático pode e deve ser acessível a todos, e consciência de seu papel na superação dos preconceitos, traduzidos pela angústia, inércia ou rejeição, que muitas vezes ainda estão presentes no ensino-aprendizagem da disciplina.

\section{Competências e Habilidades}

Os currículos dos cursos de Bacharelado/Licenciatura em Matemática devem ser elaborados de maneira a desenvolver as seguintes competências e habilidades.

a) capacidade de expressar-se escrita e oralmente com clareza e precisão;

b) capacidade de trabalhar em equipes multi-disciplinares

c) capacidade de compreender, criticar e utilizar novas idéias e tecnologias para a resolução de problemas.

d) capacidade de aprendizagem continuada, sendo sua prática profissional também fonte de produção de conhecimento

e) habilidade de identificar, formular e resolver problemas na sua área de aplicação, utilizando rigor lógico-científico na análise da situação-problema

f) estabelecer relações entre a Matemática e outras áreas do conhecimento 
g) conhecimento de questões contemporâneas

h) educação abrangente necessária ao entendimento do impacto das soluções encontradas num contexto global e social

i) participar de programas de formação continuada

j) realizar estudos de pós-graduação

k) trabalhar na interface da Matemática com outros campos de saber No que se refere às competências e habilidades próprias do educador matemático, o licenciado em Matemática deverá ter as capacidades de:

a) elaborar propostas de ensino-aprendizagem de Matemática para a educação básica;

b) analisar, selecionar e produzir materiais didáticos;

c) analisar criticamente propostas curriculares de Matemática para a educação básica;

d) desenvolver estratégias de ensino que favoreçam a criatividade, a autonomia e a flexibilidade do pensamento matemático dos educandos, buscando trabalhar com mais ênfase nos conceitos do que nas técnicas, fórmulas e algoritmos;

e) perceber a prática docente de Matemática como um processo dinâmico, carregado de incertezas e conflitos, um espaço de criação e reflexão, onde novos conhecimentos são gerados e modificados continuamente;

f) contribuir para a realização de projetos coletivos dentro da escola básica.

\section{Estrutura do Curso}

Ao chegar à Universidade, a aluno já passou por um longo processo de aprendizagem escolar e construiu para si uma imagem dos conceitos matemáticos a que foi exposto, durante o ensino básico. Assim, a formação a formação do matemático demanda o aprofundamento da compreensão dos significados dos conceitos matemáticos, a fim de ele possa contextualizá-los adequadamente. $\mathrm{O}$ mesmo pode-se dizer em relação aos processos escolares em geral: o aluno chega ao ensino superior com uma vivência e um conjunto de representações construídas. É preciso que estes conhecimentos também sejam considerados ao longo de sua formação como professor.

Os conteúdos curriculares dos cursos de Matemática deverão ser estruturados de modo a contemplar, em sua composição, as seguintes orientações:

a) partir das representações que os alunos possuem dos conceitos matemáticos e dos processos escolares para organizar o desenvolvimento das abordagens durante $\mathrm{o}$ curso

b) construir uma visão global dos conteúdos de maneira teoricamente significativa para o aluno

Adicionalmente, as diretrizes curriculares devem servir também para otimização da estruturação modular dos cursos, com vistas a permitir um melhor aproveitamento dos conteúdos ministrados. 
Da mesma maneira almeja-se ampliar a diversidade da organização dos cursos, podendo a IES definir adequadamente a oferta de cursos seqüenciais, previsto no inciso I do artigo 44 da LDB, que possibilitariam tanto o aproveitamento de estudos, como uma integração mais flexível entre os cursos de graduação.

\section{Conteúdos Curriculares}

Os currículos devem assegurar o desenvolvimento de conteúdos dos diferentes âmbitos do conhecimento profissional de um matemático, de acordo com o perfil, competências e habilidades anteriormente descritos, levando-se em consideração as orientações apresentadas para a estruturação do curso.

A organização dos currículos das IES deve contemplar os conteúdos comuns a todos os cursos de Matemática, complementados com disciplinas organizadas conforme o perfil escolhido do aluno.

\subsection{Bacharelado}

Os conteúdos descritos a seguir, comuns a todos os cursos de Bacharelado, podem ser distribuídos ao longo do curso de acordo com o currículo proposto pela IES:

- Cálculo Diferencial e Integral

- Álgebra Linear

- Topologia

- Análise Matemática

- Álgebra

- Análise Complexa

- Geometria Diferencial

A parte comum deve ainda incluir o estudo de Probabilidade e Estatística.

É necessário um conhecimento de Física Geral e noções de Física Moderna como forma de possibilitar ao bacharelando o estudo de uma área na qual historicamente o uso da matemática é especialmente significativo.

Desde o início do curso o bacharelando deve adquirir familiaridade com o uso do computador como instrumento de trabalho, incentivando-se sua utilização para formulação e solução de problemas.

Para complementar a formação do bacharel, conforme o perfil escolhido, as IES poderão diversificar as disciplinas oferecidas, que poderão consistir em estudos mais avançados de Matemática ou estudo das áreas de aplicação, distribuídas ao longo do curso.

Em caso da formação em área de aplicação, a IES deve organizar seu currículo de forma a garantir que a parte diversificada seja constituída de disciplinas de formação matemática e da área de aplicação formando um todo coerente. É fundamental o estabelecimento de critérios que garantam essa coerência dentro do programa. 


\subsection{Licenciatura}

Os conteúdos descritos a seguir, comuns a todos os cursos de Licenciatura, podem ser distribuídos ao longo do curso de acordo com o currículo proposto pela IES:

- Cálculo Diferencial e Integral

- Álgebra Linear

- Fundamentos de Análise

- Fundamentos de Álgebra

- Fundamentos de Geometria

- Geometria Analítica

A parte comum deve ainda incluir:

a) conteúdos matemáticos presentes na educação básica nas áreas de Álgebra, geometria e Análise;

b) conteúdos de áreas afins à Matemática, que são fontes originadoras de problemas e campos de aplicação de suas teorias;

c) conteúdos da Ciência da Educação, da História e Filosofia das Ciências e da Matemática.

Para a licenciatura serão incluídos, no conjunto dos conteúdos profissionais, os conteúdos da Educação Básica, consideradas as Diretrizes Curriculares Nacionais para a formação de professores em nível superior, bem como as Diretrizes Nacionais para a Educação Básica e para o Ensino Médio.

Desde o início do curso e licenciando deve adquirir familiaridade com o uso do computador como instrumento de trabalho, incentivando-se sua utilização para o ensino de matemática, em especial para a formulação e solução de problemas. É importante também a familiarização do licenciando, ao longo do curso, com outras tecnologias que possam contribuir para o ensino de Matemática.

As IES poderão ainda organizar os seus currículos de modo a possibilitar ao licenciado uma formação complementar propiciando uma adequação do núcleo de formação específica a outro campo de saber que o complemente.

\section{Estágio e Atividades Complementares}

Algumas ações devem ser desenvolvidas como atividades complementares à formação do matemático, que venham a propiciar uma complementação de sua postura de estudioso e pesquisador, integralizando o currículo, tais como a produção de monografias e a participação em programas de iniciação científica e à docência.

No caso da licenciatura, o educador matemático deve ser capaz de tomar decisões, refletir sobre sua prática e ser criativo na ação pedagógica, reconhecendo a realidade em que se insere. Mais do que isto, ele deve avançar para uma visão de que a ação prática é geradora de conhecimentos. Nessa linha de abordagem, o estágio é essencial nos cursos de formação de professores, possibilitando desenvolver:

a) uma seqüência de ações onde o aprendiz vai se tornando responsável por tarefas em ordem crescente de complexidade, tomando ciência dos processos formadores;

b) uma aprendizagem guiada por profissionais de competência reconhecida. 
ANEXO III

\section{CONSELHO NACIONAL DE EDUCAÇÃO \\ CÂMARA DE EDUCAÇÃO SUPERIOR}

\section{RESOLUÇÃO CNE/CES 3, DE 18 DE FEVEREIRO DE 2003.(*)}

Estabelece as Diretrizes Curriculares para os cursos de Matemática.

O Presidente da Câmara de Educação Superior, no uso de suas atribuições legais e tendo em vista o disposto na Lei 9.131, de 25 de novembro de 1995, e ainda o Parecer CNE/CES 1.302/2001, homologado pelo Senhor Ministro de Estado da Educação em 4 de março de 2002, resolve:

Art. $1^{\circ}$ As Diretrizes Curriculares para os cursos de bacharelado e licenciatura em Matemática, integrantes do Parecer CNE/CES 1.302/2001, deverão orientar a formulação do projeto pedagógico do referido curso.

Art. $2^{\circ} \mathrm{O}$ projeto pedagógico de formação profissional a ser formulado pelo curso de Matemática deverá explicitar:

a) o perfil dos formandos; específico;

b) as competências e habilidades de caráter geral e comum e aquelas de caráter

c) os conteúdos curriculares de formação geral e os conteúdos de formação específica;

d) o formato dos estágios;

e) as características das atividades complementares;

f) a estrutura do curso;

g) as formas de avaliação.

Art. $3^{\circ} \mathrm{A}$ carga horária dos cursos de Matemática deverá obedecer ao disposto na Resolução que normatiza a oferta dessa modalidade e a carga horária da licenciatura deverá cumprir o estabelecido na Resolução CNE/CP 2/2002, resultante do Parecer CNE/CP 28/2001.

Art. $4^{\circ}$ Esta Resolução entra em vigor na data de sua publicação, revogadas as disposições em contrário.

ARTHUR ROQUETE DE MACEDO

Presidente da Câmara de Educação Superior 
ANEXO IV

\section{CONSELHO NACIONAL DE EDUCAÇÃO CONSELHO PLENO}

\section{RESOLUÇÃO CNE/CP 2, DE 19 DE FEVEREIRO DE 2002.(*)}

Institui a duração e a carga horária dos cursos de licenciatura, de graduação plena, de formação de professores da Educação Básica em nível superior.

O Presidente do Conselho Nacional de Educação, de conformidade com o disposto no Art. $7^{\circ} \S 1^{\circ}$, alínea "f", da Lei 9.131, de 25 de novembro de 1995, com fundamento no Art. 12 da Resolução CNE/CP 1/2002, e no Parecer CNE/CP 28/2001, homologado pelo Senhor Ministro de Estado da Educação em 17 de janeiro de 2002, resolve:

Art. $1^{\circ}$ A carga horária dos cursos de Formação de Professores da Educação Básica, em nível superior, em curso de licenciatura, de graduação plena, será efetivada mediante a integralização de, no mínimo, 2800 (duas mil e oitocentas) horas, nas quais a articulação teoria-prática garanta, nos termos dos seus projetos pedagógicos, as seguintes dimensões dos componentes comuns:

I - 400 (quatrocentas) horas de prática como componente curricular, vivenciadas ao longo do curso;

II - 400 (quatrocentas) horas de estágio curricular supervisionado a partir do início da segunda metade do curso;

III - 1800 (mil e oitocentas) horas de aulas para os conteúdos curriculares de natureza científico cultural;

IV - 200 (duzentas) horas para outras formas de atividades acadêmico-científicoculturais.

Parágrafo único. Os alunos que exerçam atividade docente regular na educação básica poderão ter redução da carga horária do estágio curricular supervisionado até o máximo de 200 (duzentas) horas.

Art. $2^{\circ}$ A duração da carga horária prevista no Art. $1^{\circ}$ desta Resolução, obedecidos os 200 (duzentos) dias letivos/ano dispostos na LDB, será integralizada em, no mínimo, 3 (três) anos letivos.

Art. $3^{\circ}$ Esta resolução entra em vigor na data de sua publicação.

Art. $4^{\circ}$ Revogam-se o $\S 2^{\circ}$ e o $\S 5^{\circ}$ do Art. $6^{\circ}$, o $\S 2^{\circ}$ do Art. $7^{\circ}$ e o $\S 2^{\circ}$ do Art. $9^{\circ}$ da Resolução CNE/CP 1/99.

ULYSSES DE OLIVEIRA PANISSET

Presidente do Conselho Nacional de Educação 